\title{
Szénhidrátbontó enzimek gátlásának vizsgálata STZ indukált diabetes mellitus egérmodellben
}

\section{Takács István Gábor \\ Doktori értekezés}

Témavezetők:

Dr. Pósa Anikó

Egyetemi adjunktus

Dr. Szekeres András

Tudományos fömunkatárs

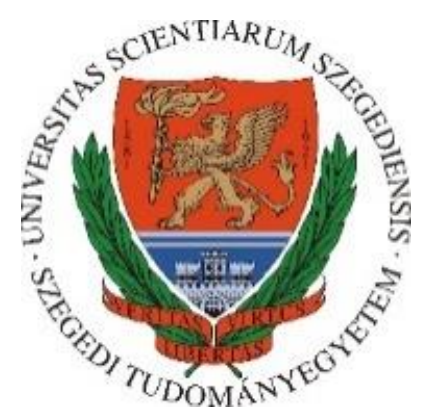

SZEGEDI TUDOMÁNYEGYETEM

TERMÉSZETTUDOMÁNYI ÉS INFORMATIKAI KAR

Mikrobiológiai Tanszék

\section{SZEGED}

2018 


\section{Tartalomjegyzék}

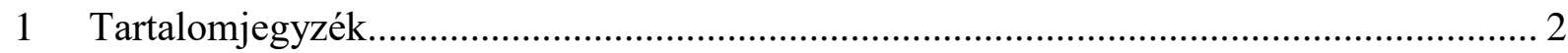

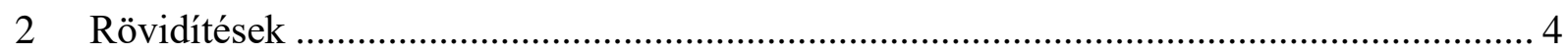

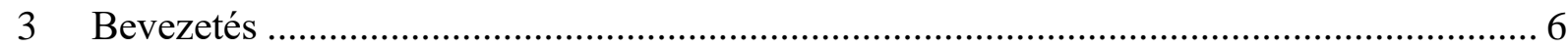

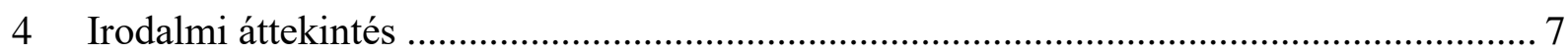

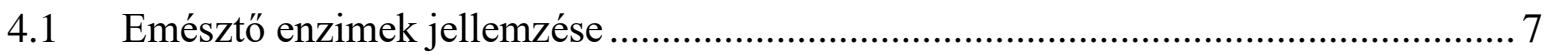

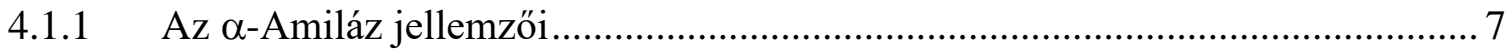

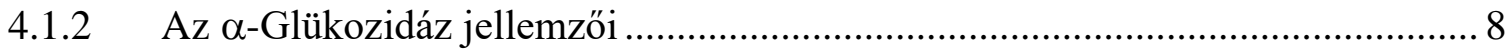

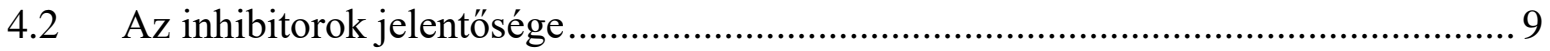

4.2.1 Az akarbóz, mint glikozid hidroláz inhibitor .................................................. 10

4.2.2 Természetes eredetü glikozid-hidroláz gátló anyagok ...................................... 11

4.3 Állatkísérleti modellek ................................................................................. 14

5 A kísérletekben szereplő növények bemutatása ........................................................... 17

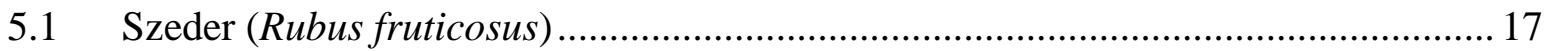

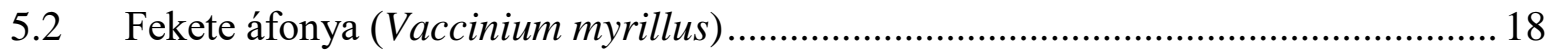

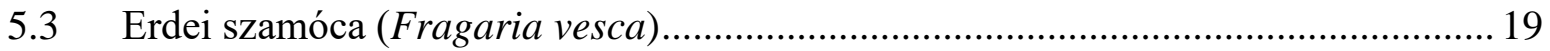

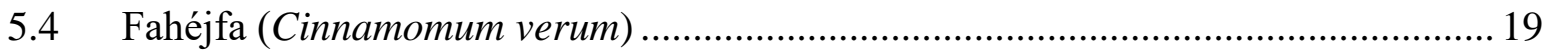

5.5 Szegfüszegfa (Syzygium aromaticum) …............................................................. 20

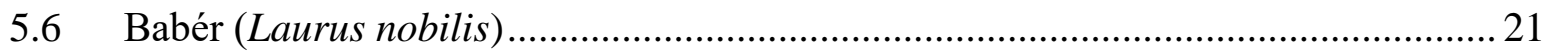

5.7 Amerikai tőzeg áfonya (Vaccinium macrocarpon ) .............................................. 21

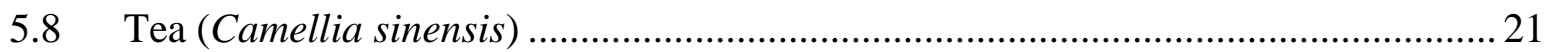

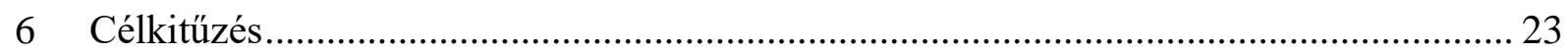

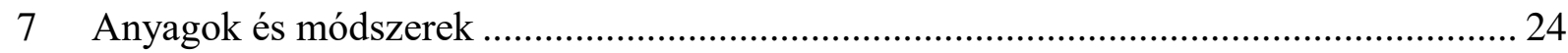

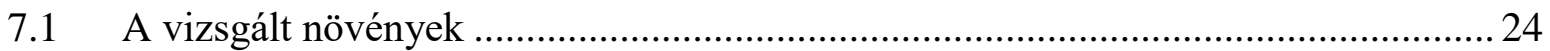

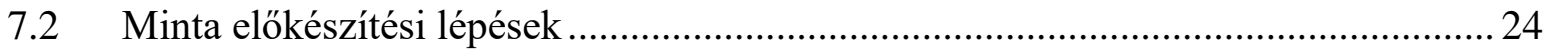

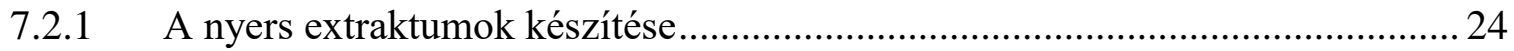

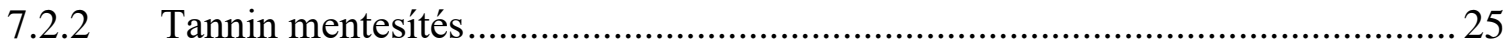

7.3 A növényi extraktumok hatása a glikozidhidroláz enzimekre................................. 25

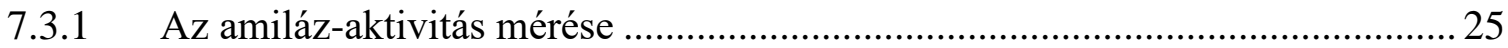

7.3.2 Az $\alpha$-glükozidáz gátlásának mérése ............................................................... 27

7.4 Az antioxidáns kapacitás mérése .......................................................................... 28

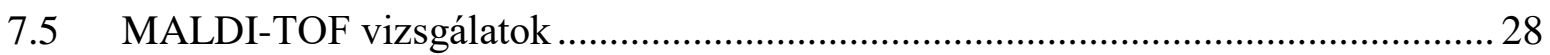

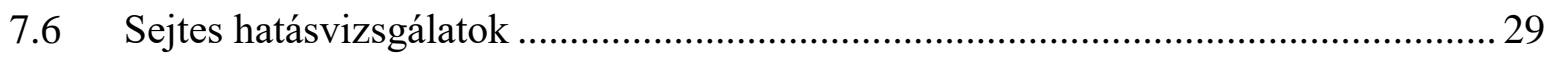


7.6.1 Valós idejű citotoxicitási teszt H9c2 sejteken ................................................29

7.6.2 Citoprotekciós kísérlet menete RTCA-SP rendszeren ....................................... 30

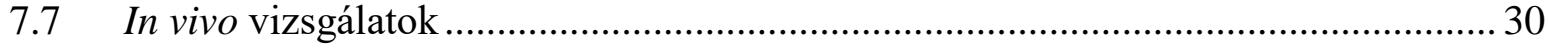

7.7.1 Magas zsír és szacharóz tartalmú prediabéteszes elhízás modell alkalmazása a

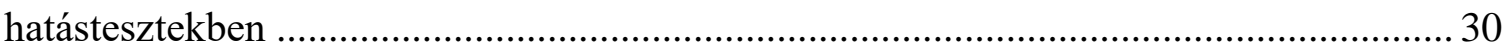

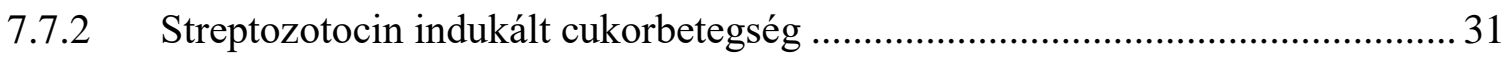

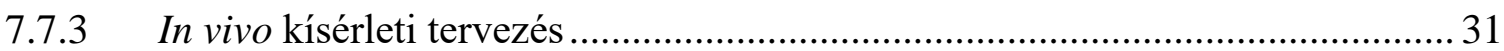

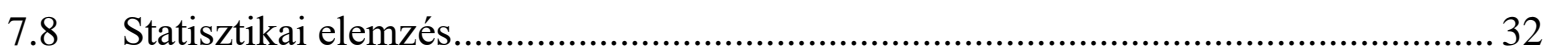

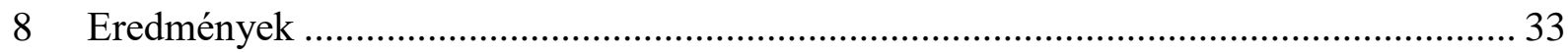

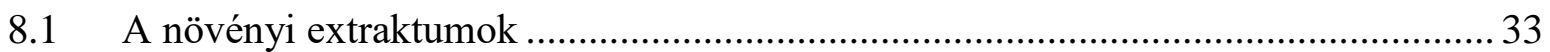

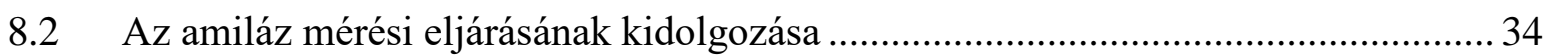

8.2.1 A CNP-G7 szintézis és a tisztítás ellenörzése ................................................... 34

8.2.2 Az optimális szubsztrát koncentráció meghatározása ....................................... 35

8.3 A növényi extraktumok hatása a glikozid-hidroláz enzimekre ............................... 38

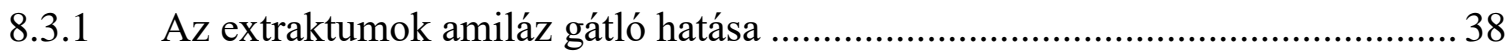

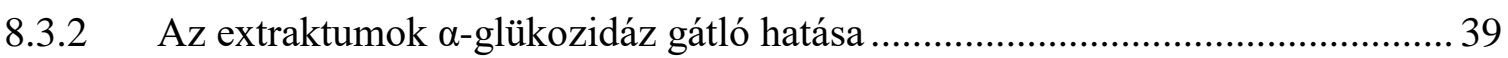

8.3.3 A keverékképzés hatása a glikozid-hidroláz enzimekre ................................. 40

8.3.4 A glikozid-hidroláz enzimekre gyakorolt hatás összefoglalása ........................ 40

8.3.5 Tanninmentesítés hatása a glikozid -hidroláz enzimek gátlására....................... 40

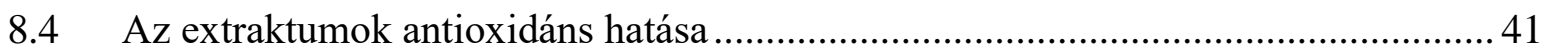

8.5 A növényi extraktumok tömegspektrometriás analízise......................................... 42

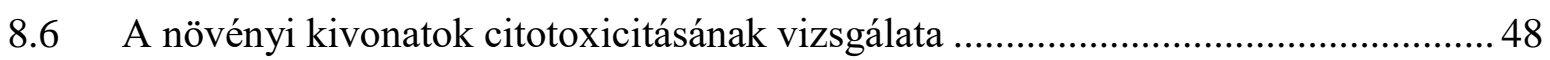

8.7 A növényi kivonatok citoprotekciójának vizsgálata............................................. 49

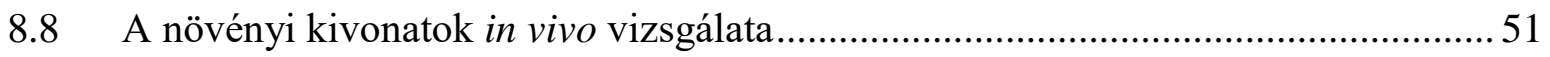

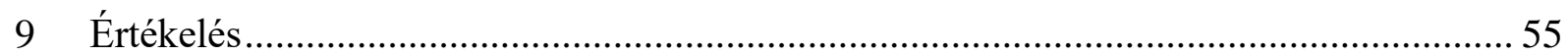

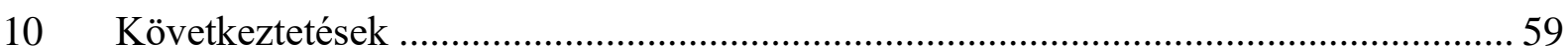

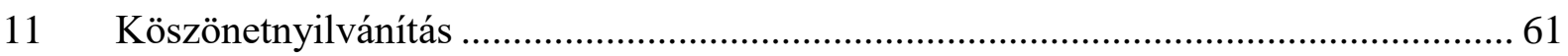

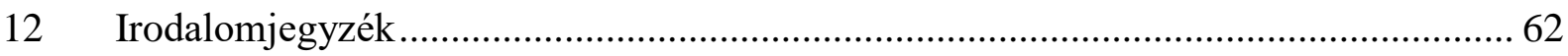

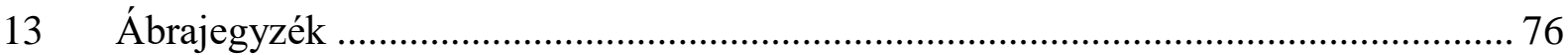

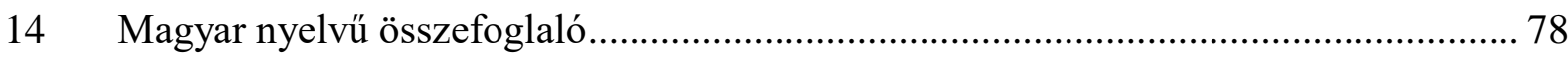

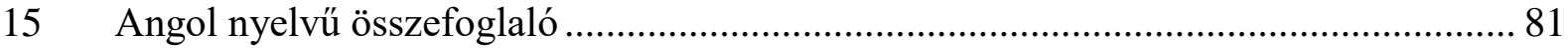




\section{Rövidítések}

AMPK = adenozin-monofoszfát-aktivált protein-kináz

BCL-2 = B-sejt CLL / Lymphoma 2

$\mathrm{CAT}=$ kataláz

CNP = 2-klór-4-nitrofenil

CNP-G7 = 2-klór-4-nitrofenil- $\beta$-D-maltoheptaóz

DNS $=$ dezoxiribonukleinsav

G6-Aca és G12-Aca = olyan akarbóz amelyek a nem redukáló végen 6 illetve 12 glükóz egységet tartalmaz

G6P = glükóz-6-foszfát

GLUT2 = Glükóz transzporter 2

GLUT4 = Glükóz transzporter 4

GPx = glutation-peroxidáz

HbAlc $=$ glikolizált hemoglobin

HFHS = magas zsírtartalmú és magas szacharóz tartalmú

HPLC = High Performance Liquid Chromatography (nagy hatékonyságú folyadék kromatográfia)

HSA = Human Saliva Amilase (humán nyál $\alpha$-amiláz)

IC50= az 50\%-os gátláshoz tartozó inhibitor koncentráció,

ICR (CD-1. ®. ) Institute for Cancer Research; Caesarean Derived-1 = albínó fehér egér

$\mathrm{KM}=$ a szubsztrát affinitását jellemző paraméter.

$\mathrm{LD}_{50}=$ Lethal Dose $=$ halálos adag

MALDI = Matrix Assisted Laser Desorption Ionization (Mátrix által segített lézer deszorpció ionizáció) 
$\mathrm{MeCN}=$ acetonitril

$\mathrm{MeOH}=$ metil-alkohol

MES-puffer

$\mathrm{NADPH}=$ nikotinamid-adenin-dinukleotid-foszfát

PEPCK = foszfo-enolpiruvát-karboxiláz

$\mathrm{p}-\mathrm{NP}=p$-nitrofenil

$\operatorname{PPAR} \gamma=$ peroxiszóma proliferátor-aktivált receptor $\gamma$

ROS $=$ Reactive Oxigen Species (reaktív oxigénformák)

$\mathrm{RP}=$ Reversed Phase (fordított fázisú)

$\mathrm{S}=$ szubsztrátkoncentráció

SOD = szuperoxid-diszmutáz

$\mathrm{STZ}=$ streptozotocin

TNF- $\alpha=$ tumor nekrózis faktor $\alpha$

TOF = Time-Of-Flight (repülési idő ) 


\section{Bevezetés}

A leggyakrabban előforduló népbetegségek, mint az elhízás és a 2-es típusú cukorbetegség, a hipertónia incidenciája az elmúlt évtizedekben riasztó mértékben növekedett. Mivel az elhízás növeli a cukorbetegség és a hipertónia kialakulásának kockázatát, a testsúlycsökkentésben alkalmazható hatóanyagok kutatása intenzíven folyik. A terápia sarokkövét sokáig az anyagcserét fokozó, szimpatomimetikus hatású hatóanyagok jelentették, ám ezek kedvezőtlen mellékhatás-profiljuk miatt kiszorulnak a repertoárból. Eredményesen használhatóak még olyan duzzadó poliszacharidok, amelyek a gyomrot kitöltve jóllakottságérzetet okoznak, a bélben pedig gátolják a tápanyagok felszívódását, de ezek hatása korlátozott mértékü, ráadásul egyéb hasznos tápanyagok felszívódását is gátolják. Hatásos kezelésként jöhetnek szóba az emészthető poliszacharidok lebontásában szerepet játszó anyagok, így az $\alpha$-glükozidáz és $\alpha$ amiláz-gátlók is (Rosak, Mertes 2009). A fentebb említett anyagok alkalmazásával enyhíthetők vagy teljesen megszüntethetők a tünetek és az életminőség javulása is várható. Az emésztőrendszerből felszívódó szénhidrát mennyiségét csökkenteni lehet a szénhidrát emésztő enzimek gátlásával vagy a felszívódás gátlásával, így támogatva az elhízás és a cukorbetegség elleni küzdelmet. Az összetett szénhidrátok közül a keményítőt fogyasztjuk táplálékainkkal a legnagyobb mennyiségben. A keményítőben lévő kötéseket kisebb részben a nyál-amiláz, nagyobb részben a hasnyálmirigyből származó pankreász-amiláz hasítja, majd az így keletkezett diszacharid és oligoszacharid egységeket további enzimek hidrolizálják. Végül monoszacharidokként kerülnek a vékonybélben felszívódásra. A keményítő emésztésében és felszívódásában az $\alpha$-amiláz és az $\alpha$-glükozidáz enzimeknek van fontos szerepe. A szervezet a szénhidrátot glikogén formájában raktározza a májban és az izomzatban. A glikogén állandóan bomlik és szintetizálódik, ez biztosítja a vércukorszint viszonylagos állandóságát. Mindezek alapján az $\alpha$-amiláz (és annak gátlása) stratégiai fontosságúnak tekinthető a szénhidrát anyagcsere befolyásolásában. A cukorbetegség az inzulin hiányából vagy az inzulinrezisztenciából eredő anyagcsere-rendellenesség. A kialakult metabolikus funkcionális zavar tovább rontja a zsír, és a fehérje anyagcserére gyakorolt hatást és emiatt szövődmények alakulhatnak ki. Ilyen szövődmény például a retinopátia, a veseelégtelenség, a neuropátia, a microangiopathia és a kardiovaszkuláris betegségek (Rosak, Mertes 2009, Najafian, EbrahimHabibi et al. 2010). Míg az 1. típusú cukorbetegség kezelése inzulinpótláson alapul, addig a 2. típusú cukorbetegség terápiás lehetőségei közé tartozik az endogén inzulin szekréció fokozása, az inzulin célszövetekbe való juttatása, valamint az oligo- és diszacharidok emésztésének a gátlása (Yamagishi, Nakamura et al. 2005). A 2. típusú diabétesz kezelésében az egyik terápiás megközelítés tehát az, hogy az étkezés utáni glükóz szint csökkenjen, amely eredményesen 
megoldható a glükóz felszívódás gátlásán keresztül a szénhidrátot hidrolizáló enzimek, mint például az $\alpha$-amiláz és a $\alpha$-glükozidáz gátlásával (Rosak, Mertes 2009, Mosca, Boniglia et al. 2008, Kandra L, 2003). A terápia hatására csökken a vér glükóz szintje és nem alakul ki az étkezés utáni hirtelen magas vércukorszint (Najafian, Ebrahim-Habibi et al. 2010, Mosca, Boniglia et al. 2008).

Kutatásaink során olyan növényi kivonatokat kerestünk, melyek alkalmazhatóak lehetnek a 2-es típusú cukorbetegség kezelésére. Előállítottuk a kivonatokat és azok biológiai hatásait in vitro és in vivo rendszerekben is vizsgáltuk.

\section{$4 \quad$ Irodalmi áttekintés}

\subsection{Emésztő enzimek jellemzése}

\subsubsection{Az $\alpha$-Amiláz jellemzői}

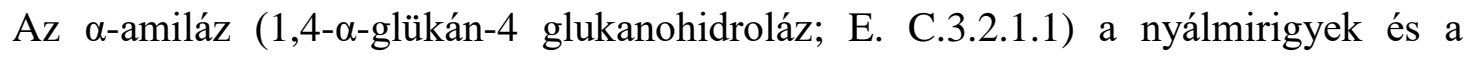
hasnyálmirigy egyik fő szekréciós terméke (Kandra L, 2003), amely megtalálható a mikroorganizmusokban, a növényekben és magasabb rendü szervezetekben (Brayer, Luo et al. 1995). Az $\alpha$-amilázok endo enzimek, melyek katalizálják a keményítő hidrolízisét rövidebb oligoszacharidokra. A hasítás az $\alpha-(1 \rightarrow 4)$ glikozidos kötések mentén történik (Brayer, Luo et al. 1995). Sem a keményítő lebomlásakor keletkező terminális maradékot, sem az elágazás $\alpha$ 1,6-kötéseit nem hasítja (Whitcomb, Lowe 2007). A végterméket különböző hosszúságú oligoszacharidok és $\alpha$-dextrinek alkotják, mint a maltóz, maltotrióz és elágazó oligoszacharidok, amelyek 6-8 glükóz egységből állnak és $\alpha-1,4$ és $\alpha-1,6$ kötéseket is tartalmaznak (Whitcomb, Lowe 2007). A humán $\alpha$-amiláz egy klasszikus kálcium tartalmú enzim, 512 aminosavból álló egyetlen polipeptid lánc, amelynek 57,6 kDa a molekulasúlya (Whitcomb, Lowe 2007). A kálciumion szükséges a harmadlagos szerkezet és az optimális enzimatikus aktivitás kialakításához (Boel, Brady et al. 1990). A pH optimuma 6,0, de megtartja az eredeti aktivitását, ha a pH 4,6 és 6,8 között van, ami egy viszonylag széles $\mathrm{pH}$ tartománynak számít. Az aktivitás 50\% fölötti, ha a pH 4,7 és 9,0 között van. Az enzim nem stabil pH 3,5 alatt és 10,0 pH-érték felett (Dutta T, Jana M, Pahari PR, Bhattacharya T, 2006). Egyes fémionok, mint a higany és a lítium ion teljesen megszüntetik az amiláz aktivitását, míg a réz, a magnézium és az ólom akár 95\% aktivitáscsökkenést okoznak. Ezzel szemben bizonyos fémionok fokozzák az aktivitást, a vas, a bárium, kobalt, ezüst és a mangán akár 130-200\% aktivitásemelkedést is eredményezhetnek (Dutta T, Jana M, Pahari PR, Bhattacharya T, 2006, 
Yamaguchi, Tokunaga et al. 2011). Jelenleg öt $\alpha$-amiláz kódoló gént azonosítottak a humán 1. kromoszóma 1q2-es helyen. Három gén közülük (amiláz 1A, amiláz 1B, és amiláz 1C) a nyálamilázt, másik két gén (amiláz 2A és amiláz 2B) a hasnyálmirigy-amilázt kódolja (Groot, Bleeker et al. 1988). A humán nyál- és hasnyálmirigy- $\alpha$-amiláz nagyfokú aminosavszekvenciahasonlóságot mutat (97\%), és a katalitikus domének is megegyeznek (Brayer, Luo et al. 1995). Az aktív centrumban található legalább egy erősen konzervált fehérjerégióhoz kötött kálciumion kötőhely, ami stabilizálja a háromdimenziós szerkezetet, és mint allosztérikus aktivátor müködik. A szubsztrátkötőhely 5 alhelyet (-3 -2 -1 +1 +2) tartalmaz (Brayer, Sidhu et al. 2000). Az eredmények azt mutatják, hogy ugyanaz a zseb ("-1", "-2", és "-3”) a döntő jelentőségü mindkét enzim katalitikus reakciójában (Brayer, Sidhu et al. 2000). Ez azért fontos, mert ez alapján a humán nyál $\alpha$-amilázon hatékony gátlószerek várhatóan a keményítő hidrolízisben nagyobb szerepet játszó pankreász eredetủ $\alpha$-amilázt is gátolják.

A humán nyál $\alpha$-amiláz három különböző biológiai funkcióval rendelkezik a szájüregben. Hidrolitikus aktivitása révén megkezdi a keményítő bontását oligoszacharidokra továbbá több bizonyíték utal arra, hogy kötődik a fogzománchoz és szerepet játszik a dentális plakk kialakulásában, valamint nagy affinitással kötődik a Streptococcusokhoz és egyéb baktériumokhoz. A hidrolízis termékeket a baktériumok tejsavvá metabolizálják. A savtermelés a fogzománc feloldódásához és így a fogszuvasodás kialakulásához vezet (Scannapieco, Torres et al. 1993). Klinikai diagnosztikai szempontból fontos indikátor a nyál- és hasnyálmirigy enzimek szérumszintje, mert patológiás rendellenességekben differenciál diagnosztikus szerepük van (például akut hasnyálmirigy gyulladás, nyálmirigy- és fültőmirigy-gyulladás esetében).

\subsubsection{Az $\alpha$-Glükozidáz jellemzői}

Az a-glükozidáz vagy más néven maltáz (EC 3.2.1.20) egy szénhidrát-hidroláz, amely felszabadítja az $\alpha$-glükózt terminálisan a nem redukáló $\alpha-(1 \rightarrow 4)$ végekről és az $\alpha$-D-glükóz $\alpha$ $(1 \rightarrow 4)$ térállású hidroxilt tartalmazó glükóz glikozidjait hidrolizálja. Az $\alpha$-glükozidáz lebontja a keményítőt és a diszacharidokat glükózzá. Az enzim a szacharózt is hidrolizálja mert ezek is tartalmaznak $\alpha$-glikozidos kötéseket. 


\subsection{Az inhibitorok jelentősége}

Az inhibitorok kis molekulatömegü vegyületek, amelyek már igen kis mennyiségben, csökkenthetik vagy teljesen gátolják az enzimek aktivitását (Sharma 2012). Az inhibitor módosíthatja az enzim aktív centrumában lévő aminosavakat vagy több aminosav oldalláncot, amelyek felelösek az enzim katalitikus aktivitásáért. Szervezetünkben is létezik több természetes enzim inhibitor, mint például az antithrombin és az antitripszin, melyek fiziológiás körülmények között szabályozzák az enzimaktivitást a szervezetben. A természetes enzim inhibitorok, amelyek származhatnak közvetlenül növényekből vagy bármilyen más természetes forrásból hasonló hatásokat fejtenek ki. Reverzibilisen vagy irreverzibilisen csökkentik, vagy teljesen gátolják az enzim katalitikus aktivitását. Irreverzibilis inhibitorok általában kémiailag változtatják meg az enzimet, a reverzibilisek pedig nem kovalensen kötődnek és különböző gátlási típusaik vannak attól függően, hogy ezek az inhibitorok hogyan kötődnek az enzimhez vagy az enzim - szubsztrát komplexhez. A legtöbb hatóanyag az enzimgátláson keresztül fejti ki a hatását, mert katalitikus kölcsönhatásba lép a cél-enzimmel (Copeland 2013). A reverzibilis inhibitorok két féle gátlást hoznak létre a kompetitív, és a nem-kompetitív gátlást. A kompetitív gátlásnál a szubsztrát és inhibitor nem kötődik az enzimhez egyidejüleg, ezért a kompetitív inhibitor verseng a szubsztrát aktív helyéért. A nem kompetitív inhibitor egyformán jól kötődik mind a szabad enzimhez mind a szusztráthoz és így egy inaktív enzim-szubsztrát-inhibitor komplexet alkot. A 2-es típusú cukorbetegség egyik terápiás kezelése az étkezés utáni hiperglikéma csökkentése. Ezt úgy lehet elérni, hogy késleltetjük a glükóz felszívódását az emésztőrendszerben a szénhidrát hidrolizáló enzimek gátlása révén. Az $\alpha$-amiláz és az $\alpha$ glükozidáz enzimek felelősek az oligoszacharidok és diszacharidok monoszacharidokká való bontásáért és ezek felszívódásáért. Ezen enzimek gátlásával késleltethetjük a glükóz felszívódás sebességet azáltal, hogy megakadályozzuk a szénhidrátok emésztését és ennek következtében csökkentjük a plazma glükóz emelkedését. A szintetikus antidiabetikus készítmények, mint például az akarbóz, fontos molekulák, melyek csökkentik az étkezés utáni vércukorszintet (Singh, Dartois et al. 2010). Az akarbóz a klinikai gyakorlatban alkalmazott terápiás hatóanyag, amely hatásosan csökkenti a vércukorszintet, azonban több mellékhatása is ismert (Shobana, Sreerama et al. 2009). A káros mellékhatások elkerülése érdekében, a jelenleg használt szintetikus inhibitorok alkalmazása mellett szükségesé vált új, természetben előforduló inhibitorok kutatása. Az utóbbi években több tanulmány jelent meg a potenciális természetes antidiabetikus termékekkel kapcsolatban. A bibliográfiai adatok azt jelzik, hogy a 
flavonoidokat és a fenolos vegyületeket nagy számban vizsgálták a humán betegségek kezelésében. Az ezekből származó ismeretek tovább bővítik a jövőbeli kutatási lehetőségeket, hogy melyik vegyület csoport lehet potenciális új célpont. Amellett, hogy flavonoidok magas enzim gátló kapacitását, erős antioxidáns és gyulladás gátló tulajdonságát több tanulmány is bizonyította, ezeknek a vegyületeknek kiemelt jelentősége lehet a megelőzésben és a terápiában. A jövőbeli kutatások célja, szabványos protokollok kidolgozása annak érdekében, hogy milyen módon lehet leghatékonyabban tesztelni a potenciális növényi inhibitorokat. Annak ellenére, hogy nagyszámú fenolos vegyületet vizsgáltak in vitro körülmények között, csak kevés vegyületet teszteltek tovább in vivo állat modellben.

\subsubsection{Az akarbóz, mint glikozid hidroláz inhibitor}

Széleskörüen ismert szénhidrát típusú $\alpha$-amiláz inhibitor az akarbóz. Az enzim gátlók gyógyszerek csoportjába tartozó úgynevezett $\alpha$-glikozidáz gátló amelyet a 2-es típusú cukorbetegség kezelésére alkalmazzák. Az akarbóz több enzimnek is erős kompetitív inhibitora, így például a glükozidázoknak, illetve a glükoamilázoknak, de az $\alpha$-amiláz gátló hatása is fontos. Szerkezetét tekintve egy pszeudo-tetraszacharid (1. ábra).

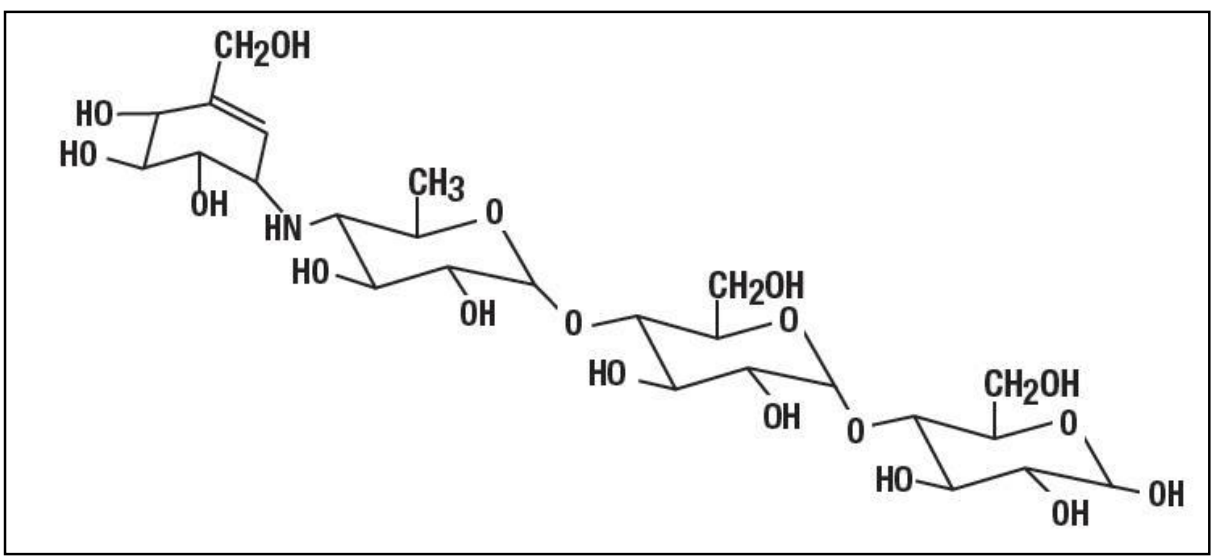

1. ábra Az akarbóz szerkezete

https://www.drugs.com/cdi/acarbose.html 
A hatóanyag szinte egyáltalán nem szívódik fel, hatását elsősorban a vékonybélben fejti ki. Késlelteti a szénhidrátok emésztését, ennek következtében lelassítja a szénhidrátokból származó glükóz felszabadulását (Cheng, Fantus 2005). A vércukorszint napi ingadozását csökkenti és az átlagos vércukorszint-értékek is mérséklődnek. Önmagában nem okoz hipoglikémiát. A cukorbetegek diétás kezelése mellett, kiegészítő kezelésként alkalmazzák. Jótékony hatásai mellett azonban számos, nem kívánatos mellékhatással is rendelkezik. A vékony- és a vastagbélben glikozidázok hatására metabolizálódik, melynek eredményeképp akarviozin-glükóz és glükóz keletkezik (Gyemant, Kandra et al. 2003). A bomlástermékek a vastagbélbe érnek, ahol a D-glükóz mikrobiális fermentációjának hatására kellemetlen gasztrointesztinális panaszokat okoznak (puffadás, hasmenés és felfúvódás) (Gyemant, Kandra et al. 2003). Ezek a mellékhatások gyakoriak az $\alpha$-amiláz inhibitorok alkalmazásánál, a betegek több mint 20\%-ánál fordulnak elő (Chiasson, Josse et al. 2002). Gyakran az ilyen hatások vezetnek a kezelés befejezéséhez. Az $\alpha$-amiláz- és $\alpha$-glükozidáz inhibitorok használata ellenjavallt olyan betegeknél, akiknek irritábilis bél szindrómájuk vagy súlyos vese- illetve májkárosodásuk van, továbbá gyulladásos bélbetegségben sem alkalmazhatóak (Cheng, Fantus 2005). Az utóbbi évtizedben több módosított akarbóz származékot állítottak elő enzimatikus, illetve teljes vagy részleges kémiai átalakítások révén (Kandra, Remenyik et al. 2005). Ennek eredményeképpen sikerült olyan potenciális inhibitorokat kifejleszteni, amelyek az akarbóznál jelentősebb gátló aktivitással rendelkeznek és kellemetlen panaszokat nem okoznak (Qian, Nahoum et al. 2001). Ilyenek például az akarbóz enzimes transzglikozilezésével előállított vegyületek az izoakarbóz (amiben egy glükóz egység a redukáló végről a nem redukáló végre került), a G6-Aca és G12-Aca (amelyek a nem redukáló végen 6 illetve 12 glükóz egységet tartalmaznak) (Robyt JF 2005).

\subsubsection{Természetes eredetü glikozid-hidroláz gátló anyagok}

A gyógynövényeket évszázadok óta használják gyógyászati célokra, így a 2-es típusú cukorbetegség kezelésére is. Egyes növények által termelt másodlagos metabolitok, mint lehetséges $\alpha$-amiláz-inhibítorokat már részletesen is vizsgáltak (Helmstadter 2012, Saha, Verma 2012). Ezek a növények által termelt másodlagos metabolitok keletkezhetnek primer metabolitok különböző módosulásain keresztül, mint a metiláció, hidroxilezés és glikolizáció. Ezek a vegyületek természetesen sokkal összetettebbek, mint a primer metabolitok és 
különböző szempontok szerint osztályozhatóak pl. a kémiai szerkezetük, összetételük és oldékonyságuk szerint. Megfigyelhetö, hogy azonos növénycsaládba tartózó egyedek hasonló bioaktív vegyületeket termelnek. A növényi szekunder metabolitok termelését a konkrét környezeti körülmények erősen befolyásolják, ezért az extrakciós és tisztítási lépések optimalizálását nagyon megnehezíthetik az évenként változó éghajlati körülmények. Ennek eredményeként a kereskedelmi forgalomban beszerezhető növényi eretetű termékekre, ezen belül a gyógyszeralapanyagokra, természetes aromákra, illatanyagokra úgy tekintenek, mint nagy értékü bioaktív termékekre, mert előállításuk magas szintü technológiát igényel. Ezeknek a természetes anyagoknak a táplálkozási és egészségügyi vonatkozásai széles körben elfogadottak. A levelekben, gyümölcsökben és zöldségekben megtalálható vegyületek nevezetesen a flavonoidok, polifenolok, fenolos savak, tanninok stb. jelenléte és hatása már igazolt. A fenolos savak felelösek az egyes növényi eredetü élelmiszerekben a savanyú és a keserü ízért, az astringens tulajdonságért, a gyomor nyálkahártyára gyakorolt, valamint az antioxidáns hatásért. Ezeket a vegyületeket tehetjük felelősé az egészségünket pozitívan befolyásolható hatásokért, vagy a 2-es típusú cukorbetegségre gyakorolt aktív preventív hatásért. Több növényi kivonat esetében bizonyították az $\alpha$-amiláz aktivitás csökkentő hatást, így ezek fontos kiindulási alapul szolgálhatnak a 2-es típusú cukorbetegség kezelését célzó anyagok kutatásában. Széles a skálája a növényi eredetű, amiláz-inhibitor vegyületeknek. Főleg alkaloidok, flavonoidok, egyéb polifenolok, galaktomannán, poliszacharidok, peptidoglikánok, guanidin-származékok, szteroidok, glikopeptidek és terpenoidok esetén bizonyították a biológiai aktivitást (Mentreddy 2007). A növényi magvak, legföképp a hüvelyesek és a gabonafélék magvai gazdag forrásai a számtalan fehérje típusú inhibitornak, amelyek az $\alpha$ amilázokon, vagy más poliszacharidbontó enzimeken keresztül fejtenek ki gátló hatást. A növények ezekkel a gátló anyagokkal próbálnak védekezni az őket fogyasztó rovarok és azok lárvái ellen. A rovar amilázok hasonló szerkezetűek, mint a humán nyál amiláz. Különböző növényfajokból izoláltak olyan fehérjeszerü $\alpha$-amiláz-inhibítorokat ( $\alpha \mathrm{AI})$, amelyek gátolják mind a nyál-, mind a hasnyálmirigy-amilázt (Wang HH, Chen CL, Jeng TL, Sung JM, 2011). A veteménybab (Phaseolus vulgaris) ilyen fehérjeszerü inhibitorokat tartalmaz (Le BerreAnton, Bompard-Gilles et al. 1997). A babban lévő $\alpha$-amiláz gátlók jelenléte lehet a racionális oka annak, hogy a babhüvely a diabétesz és az elhízás elleni teakeverékek alkotója (Wang HH, Chen CL, Jeng TL, Sung JM, 2011).

A fenolos vegyületeket és a flavonoidokat széles körben tanulmányozták, mint $\alpha$-amiláz gátlókat, és nagy jelentőséget tulajdonítanak az alkalmazásuknak a keményítők emészthetőségének a szabályozásában (Gyemant, Kandra et al. 2003, Cheng, Fantus 2005) 
Tadera és munkatársai (Tadera, Minami et al. 2006) több flavonoidot teszteltek $\alpha$-amiláz gátlásra. Az in vitro eredményekből az látszik, hogy a gátló hatás jól korrelál a flavonoidok Bgyürüjén lévő hidroxilcsoportok számával és az ebből adódó szerkezeti struktúrákból követeztetni lehet a gátlás nagyságára. In vitro humán nyál $\alpha$-amiláz gátlását és a flavonoidok szerkezeti különbségeit vizsgálták 19 flavonoid esetében (Lo Piparo, Scheib et al. 2008) és kimutatták, hogy a flavonoidok enzimgátló hatása függ a polifenolok hidroxil-csoportjai és a ligandumok hidrogén kötései közötti aktív katalitikus helyek számától. Xiao és munkatársai (Xiao, Ni et al. 2013) vizsgálták a flavonoidok szerkezete és a polifenolok $\alpha$-amiláz gátlása közötti összefüggéseket. Arra a következtetésre jutottak, hogy a hidroxilezés javította az $\alpha$ amiláz gátlását. Más fenolos osztályba tartózó vegyületek, mint például hidroxi-fahéjsavak és tanninok kevésbé hatékonyak az $\alpha$-amiláz és $\alpha$-glükozidáz gátló hatásban, mint a flavonoidok (Sales, Souza et al. 2012). A fenolos vegyületek közül elsősorban a flavonoidok nyújthatnak védőhatást a hiperglikémia talaján kialakult krónikus betegségek elleni védelemben a keményítő emésztés gátlása révén. A kutatási adatok azt mutatták, hogy a különböző fenolos vegyületek hatékony inhibitorai számos enzimnek. Az enzimek gátlásával több patofiziológiás folyamathoz kapcsolódó betegséget lehet széles körben kezelni, mint például a magas vérnyomást, a 2-es típusú diabéteszt, az elhízást és az Alzheimer-kórt. A fenolos vegyületeket ezért többfunkciós vegyületként tartják számon, amelyeknek széles a biológiai spektruma és hatékonyan támogatják az emberi egészséget. Ezek a vegyületek különböző hatás mechanizmusok útján fejtik ki hatásukat és ezért hatalmas potenciál rejlik bennük, mert számos betegség megelőzésben és kezelésében alkalmazhatóak.

A polifenolos vegyületek jellemzően jó $\alpha$-amiláz gátlók. Ezek a vegyületek széles körben elterjedtek, jelen vannak a növényekben és a gyümölcsökben is, a normál étrend részét képezik. Jótékony hatásukat különféle metabolikus betegségeknél, például a cukorbetegségnél, elhízásnál, szív-és érrendszeri betegségeknél, érelmeszesedésnél egyaránt kimutatták (Nijveldt, van Nood et al. 2001, Tadera, Minami et al. 2006), Bizonyos növényi eredetü polifenolok, mint a kvercetin, illetve a katechinszármazékok hatékony inhibitorai az $\alpha$-amiláznak. Egyes növényekben további vizsgálatok során hatásosnak találták az amiláz gátlásra mikromoláris tartományban a kalkont (1,3-difenil-2-propén-1-on), mely egy flavonoid prekurzor (Ferrer, Austin et al. 2008, Verhoeyen, Bovy et al. 2002). A kalkonnal kezelt patkányokon testsúlycsökkenés volt megfigyelhető cukorbeteg és nem cukorbeteg egyedekben is. Ez a hatás az $\alpha$-amiláz gátló tulajdonságból következik (Najafian, Ebrahim-Habibi et al. 2010). Egyes származékai hipoglikémiás hatást fejtenek ki, növelik a zsírszövet glükóz felvételét, illetve elősegítik a glikogén szintézisét (Anderson, Broadhurst et al. 2004). 
A növényi cserzőanyagok széles körben elterjedtek, gyakran jelen vannak az éretlen gyümölcsökben, majd az érés során eltünnek. Viszonylag nagy molekulatömegü anyagok. Két fő csoportba lehet őket sorolni: a hidrolizálható, illetve a kondenzált tanninok csoportjaiba. A hidrolizálható tanninoknál egy cukor molekulához kapcsolódnak a galluszsav egységek, míg a kondenzált tanninok összetett polimerek, ahol az építőelemek általában katechin típusúak (Kandra, Gyemant et al. 2004). A cserzőanyagokban gazdag vörösborról már kimutatták, hogy csökkenti a szérum glükóz szintjét, keményítőben gazdag étkezés után, nem-inzulinfüggö diabétesz mellitusban (Gin, Rigalleau et al. 1999). Ez a hatás feltehetöleg részben azért van, mert a tanninok gátolják az $\alpha$-amiláz aktivitását. Mivel a szintetikus $\alpha$-amiláz inhibitoroknak kellemetlen mellékhatásai lehetnek (Alagesan K, Raghupathi PK, Sankarnarayanan S, 2012), a növényi eredetű gátlószerek kutatása igen perspektivikus, különösen akkor, ha olyan növény a kiindulási nyersanyag, amelynek ártalmatlansága már bizonyított. A gyümölcsök és zöldségek természetes forrásai a polifenolos vegyületeknek, amelyek egy része gátolja az $\alpha$-amilázt. Ennek szerepe lehet abban, hogy a zöldségben és gyümölcsben dús étrend bizonyítottan csökkenti a cukorbetegség és elhízás veszélyét. A gyógynövények kutatása nagyban hozzájárulhat ahhoz, hogy az amiláz gátlásán keresztül ható természetes vegyületekre leljünk a vércukorszint csökkentése érdekében.

\section{3 Állatkísérleti modellek}

$\mathrm{Az}$ állatmodellek alkalmasak arra, hogy a bizonyos antidiabetikus vegyületeket teszteljenek és a vizsgálati anyagok eredményeit felhasználva további fejlesztések alapjait képezzék. Ezekben az állatokban létrehozhatóak a humán betegséggel egyenértékü metabolikus, és morfológiai változások, a mögötte kialakuló szövődményekkel együtt. A kémiai indukció a leggyakrabban használt eljárás a cukorbetegség kiváltására a kísérleti állatokban. Ezekben a kísérleti állatokban a diabétesz kiváltása után el lehet kezdeni a megfelelö terápiás hatóanyaggal történő kezelést. Az állatmodellek további célja, hogy kiderítsük az esetleges toxicitási problémákat és megismerjük a gyógyszer-metabolizmus útvonalait, amelyek tovább segítenek abban, hogy jobb és hatásosabb terápiás módszerek kidolgozását tegyék lehetővé. A diabétesz oka a hasnyálmirigy Langerhans $\beta$-sejtjei által termelt inzulin csökkent termelödése vagy hiánya, ami funkcionálisan hiperglikémiát okoz. Normális állapotban van egy folyamatos körforgás a $\beta$-sejtek arányában, ami a sejtek öregedésével, és pusztulásával, vagyis az apoptózissal együtt jár. A $\beta$-sejtek replikációjával és a szigetsejt-neo- 
genezisével folyamatosan cserélődnek (Dhuria, Singh et al. 2015). A diabéteszes állapotban azonban ez nem eléggé kompenzálja az inzulin szükségletet és ezért az inzulin hiány miatt kialakul a hiperglikémia. A 2-es típusú diabéteszt az abnormális glükóz homeosztázis jellemzi, ami hiperglikémiát eredményez. A cukorbetegségnek a kialakulásában a genetikai és környezeti tényezők is fontos szerepet játszanak. A diabétesznek egyes etnikai csoportokban magas az előfordulási aránya. Különösen magas az előfordulási arány az Arizonában élő Pima indiánok, és a csendes-óceáni szigetek Nauru törzs bennszülöttjei között (Wild, Roglic et al. 2004). Továbbá ismert tény, hogy 2-es típusú diabétesz jellemző lehet a spanyol és afroamerikai populációkban, és kevésbé jellemző a kaukázusi népcsoportokban. A monozigóta családi halmozódás, valamint a családi örökletes mintázatok arra utalnak, hogy a genetikai összetevők fontos kóroki szerepet játszanak a betegség kialakulásában. Bár számos gén felelős az inzulin rezisztencia kialakulásáért és több nem specifikus génhiba kifejeződésért, annak ellenére még mindig az inzulinszekrécióból és egyéb labor eredményekből következtetnek a diabéteszes állapotra. Számottevő bizonyíték arra utal, hogy a környezeti és egyéb tényezők, mint például a táplálkozás, a stressz, a fizikai aktivitás, az elhízás és az öregedés is fontos szerepet játszanak a betegség kialakulásában (Jun, Bae et al. 1999). Számos állat modell az emberi 2-es típusú diabéteszt tükrözi, ahol az elhízott állapotot vizsgálják, mivel az elhízás szorosan összefüggésbe hozható a 2-típusú diabétesz kifejlődésével (Rosenbloom, House et al. 1998). A kémiailag indukált diabétesz nem csak egy egyszerü és viszonylag olcsó modell a diabétesz patogenezisének tanulmányozására rágcsálókban, de használni lehet magasabb rendü állatokban is (Dufrane, van Steenberghe et al. 2006). Az endogén $\beta$-sejtek megsemmisítése, vagy jelentős csökkentése, csökkent inzulin termelést, megnövekedett vércukorszintet, és jelentős súlyvesztést fog eredményezni a kísérleti állatokban. A leggyakrabban használt diabetogén szerek rágcsálókban, a streptozotocin (STZ) és az alloxan (ALX). Ezeket a vegyületeket a kémiailag kiváltott diabétesz tanulmányozására használják. Ezeknek a szereknek a cukorbetegséget kiváltó dózisa nagyban függ az állat fajától és a beadás módjától (Federiuk, Casey et al. 2004). A kémiailag indukált modellek nagyon előnyösek az új antidiabetikus gyógyszerek vagy az új inzulin készítmények tesztelésére (Jansson, Eizirik et al. 1995, Sheshala, Peh et al. 2009, Graham, Janecek et al. 2011). Az STZ kémiai neve, (2-dezoxi2-(\{[metil (nitrozo)-amino]-karbonil $\}$-amino)- $\beta$-D-glükopiranóz) egy a természetben előforduló diabetogén vegyület, amelyet a Streptomyces achromogenes fermentációja során izoláltak (Bono 1976). Nagyon jól oldódik vízben és a rövid szénláncú alkoholokban (Vivek 2010). Funkcionálisan egy DNS-szintézis-inhibitor, és erős antitumor hatással is rendelkezik, amely hatás megfigyelhető bakteriális és emlős sejteken egyaránt (Eileen Dolan 1997). 
Felfedezése után kemoterápiás kezelésre használták a hasnyálmirigy szigetsejt daganatoknál (Lenzen 2008). Az STZ egy nagyon erős fehérje alkilező (Wang, Gleichmann 1998) és nitrogén-oxid donor, e kettő tulajdonsága együttesen okozza a citotoxikus hatást (Imaeda, Kaneko et al. 2002). Egy glükóz molekulát tartalmaz (dezoxi formában), amely össze van kapcsolva egy nagyon reaktív metil-nitro-karbamid molekularésszel. Erről a molekularészről feltételezik, hogy felelős a STZ citotoxikus hatásáért. A sejtmembrán glükóz GLUT2 transzporterén keresztül felveszi a sejt az STZ-t és a sejten belüli DNS-alkilezésén keresztül sejthalált okoz (Szkudelski 2001a). A béta-sejt specifikussága főként a szelektív celluláris felvétel és felhalmozódás miatt alakul ki. Mivel az STZ mérgező hatása nem specifikus kizárólag a $\beta$-sejtekre, más szövetekben, is sejthalált vált ki (Lenzen 2008). A GLUT2 receptor kisebb mértékben, más szervekben is kimutatható, mint pl. a májban és a vesében, ezért ezekben a szervekben is erősen toxikus hatás figyelhető meg (Bouwens, Rooman 2005). A STZ egy biológiailag rövid felezési idejü hatóanyag és kb. 5-15 perc alatt kiürül a szervezetből (Lee, Yang et al. 2010). A májban gyorsan metabolizálódik, és a vesén keresztül választódik ki (Karunanayake, Hearse et al. 1976). Az előbb felsorolt súlyos mellékhatások miatt erősen onkogén hatásúnak mondható (Kazumi, Yoshino et al. 1978). Már egyszeri nagy dózisú STZ is képes diabéteszt kiváltani rágcsálókban, valószínúleg a közvetlen toxikus hatást eredményeként. Megfigyelték, hogy nem minden állatra van egyformán hatása: például nyulakban az STZ hatástalan (Rerup 1970). Ugyanakkor egerekben és patkányokban a többszöri kis dózisú STZ-vel diabéteszes tüneteket indukáltak (Like, Rossini 1976, Lukic, Stosic-Grujicic et al. 1998). A rágcsálóknál jelentős nemi különbségeket figyeltek meg az STZ érzékenységét illetően. A vizsgálatok megállapították, hogy az STZ-kezelés a hím egerekben és patkányokban nagyobb érzékenységet mutatott, mint a nőstény egyedekben (Nakamura, Nagafuchi et al. 1984, Szkudelski 2001a). A kísérletek igazolták, hogy hím és nőstény C57BL/KsJ egerekben minden alkalommal szignifikáns különbséget mutatott a vér átlagos glükóz koncentrációja (Leiter 1982). Az STZ injekció kezelés után a glükóz koncentrációja magasabb volt a hímeknél a nőstényekhez képest. Ezt a csökkent érzékenységet a nőstényeknél az ösztradiolnak tulajdonították, amely képes megvédeni a hasnyálmirigy $\beta$-sejtjeit az oxidatív stressz által indukált apoptózistól (Le May, Chu et al. 2006). Az STZ-indukált cukorbetegség kiváltására több módszer és adagolási ajánlás létezik az irodalomban (Deeds, Anderson et al. 2011, Graham, Janecek et al. 2011). A diabétesz típusától függően a konkrét kísérleti protokollok nagy különbségeket mutatnak (Szkudelski 2001b, Tesch, Allen 2007, Lu, Juang et al. 1998). A dózis nagyban változik a fajok és a nemek között is. A korábbi kísérletekben azt javasolták, hogy a hiperglikémiát több alacsony dózisú STZ kezeléssel hozzák létre, amely T- 
limfocita-függő autoimmun folyamatot provokál (Rossini, Like et al. 1977, Weide, Lacy 1991). Egy másik javaslat szerint egyetlen mérsékelt dózisú STZ injekcióval (100 mg/kg) is eredményesen indukálható diabétesz hím ICR egerekben. (Deeds, Anderson et al. 2011, Ito, Kondo et al. 2001)

\section{$5 \quad$ A kísérletekben szereplö növények bemutatása}

\subsection{Szeder (Rubus fruticosus)}

A szeder a rózsafélék (Rosaceae) családjába tartozik erdőszélek, árokpartok, ligetek, legelök gyakori, tüskés, évelő cserjéje. A gyümölcsökön kívül a növény több részét, mint például a leveleket is felhasználják gyógyászati célra (Tobyn, Denham et al. 2011). A hagyományos és a tradicionális gyógyászatban alkalmazzák, mint egy antimikrobiális továbbá görcsoldó, hasmenés elleni szert. Magas antioxidáns kapacitással rendelkezik, feltehetően a galluszsav, a tanninok és a flavonoidok miatt. Egy tanulmányban összefüggést találtak az antimikrobiális aktivitás és az antioxidáns kapacitás között, így igazolva a feltételezett hatását (Martini, D'Addario et al. 2009). A szedret régóta használják Európában a cukorbetegség kezelésére. A levelek kivonata vércukor szint csökkentő hatást mutatott diabéteszes patkányokban (Bailey, Day 1989). A tanulmányt az európai szeder fajokon végezték abból a célból, hogy a növényt, mint gyógynövényt milyen indikációkban alkalmazhatják, továbbá több aktív hatóanyagot is azonosítottak benne (Verma, Gangrade et al. 2014). A szeder levél alkoholos kivonatának frakcióit aktívnak találták a nem inzulinfüggő diabétesz kezelésére és megelözésére (Xu, Zhang et al. 2006). Az eredmények vércukorszint csökkentő hatást igazoltak normál és STZ indukált diabéteszes patkányokban. Ezen túlmenően, az akut toxicitási vizsgálatok eredményei igazolták, hogy a vizes kivonat biztonságosnak tekinthető mivel az $\mathrm{LD}_{50}$ értéke meghaladta a 8,1 g/kg-ot. Ezek az eredmények azt jelzik, hogy a szeder levél kivonatának aktív komponensei hatékony vércukor szint csökkentő tulajdonsággal rendelkeznek, és potenciális forrásai lehetnek egy új orálisan alkalmazható készítménynek (Jouad, Maghrani et al. 2002a). Egy tanulmányban különféle szeder levél kivonatokat vizsgáltak normoglikémiás, glükóz indukált hiperglikémiás és alloxan indukált diabéteszes nyulak esetében. Az alloxan indukált-diabéteszes nyulak napi dózisa $5 \mathrm{~g} / \mathrm{kg}$ extraktum volt, ahol e dózis 15\%-os vércukorszint csökkenést okozott. Amikor ezt a kezelést leállították, a vér 
glükóz szintje emelkedni kezdett és újra elérte a kezdeti patológiás értékeket (Alonso, Cadavid et al. 1980, Swanston-Flatt, Day et al. 1990).

\subsection{Fekete áfonya (Vaccinium myrillus)}

Az áfonya számos felhasználása ismeretes a népi gyógyászatban. A levelek főzetét használják vizelethajtó és fertőtlenítőként a húgyúti fertőzéseknél, továbbá széles körüen használják a cukorbetegség kezelésében is (Wang, Lin 2000a). Az áfonya levelek fö bioaktív vegyületei a hidroxi-fahéjsav származékok, különösen a kloragénsav és a kávésav (Verma, Gangrade et al. 2014). A hidroxi-fahéjsavak koncentrációja magasabb a levelekben, mint a gyümölcsökben. A levelek legjelentősebb és leggyakoribb flavonoid tartalma a kempferol és a kvercetin-glikozidok. Ezen túlmenően, számos más bioaktív vegyületet lehet megkülönböztetni a levelekben, mint például a flavan-3-olokat, proantocianidineket és egyéb kumarinokat (Ieri, Martini et al. 2013). A levelek hidroxi-fahéjsav tartalma jelentősen csökken a nyár folyamán, míg a flavonoidok mennyisége gyorsan növekszik és július közepén éri el a maximumot. Ez azért fontos, hogy a különböző időpontokban szedett levelek különböző fenolsav tartalma jelentősen eltérhet (Martz, Jaakola et al. 2010), így azt javasolják, hogy a leveleket augusztus közepéig kell gyüjteni, mert akkor a legmagasabb a proantocianidok mennyisége. A növényt különböző célokra lehet használni növényi gyógyszerek és étrend-kiegészítők alapanyagául is szolgálhat. Mivel hasonló fenolos vegyületeket tartalmaz, mint a teacserje levele, (Camellia sinensis) ezért a felhasználás során helyettesíthető vele (Riihinen, Jaakola et al. 2008). Annak ellenére, hogy rendszeresen és nagy mennyiségben használják az áfonya leveleket, a diabétesz terápiában eddig csak ritkán vizsgálták és az eredmények is meglehetősen ellentmondásosak voltak (Helmstadter, Schuster 2010). 


\subsection{Erdei szamóca (Fragaria vesca)}

Az erdei szamóca egy lágyszárú évelő növény, amely a Rosaceae családba tartozik. Habár elsődlegesen a gyümölcséért termesztik, de a leveleit és a gyökerét is használják a népi gyógyászatban. A levelei jelentős mennyiségü bioaktív vegyületet tartalmaznak (CamejoRodrigues, Ascensao et al. 2003, Neves, Matos et al. 2009). A korábbi vizsgálatok igazolták, hogy az erdei szamóca kivonata nagymennyiségü polifenolos vegyületet tartalmaz, amelyek közül legfontosabbak a tanninok, proantocianidinek, flavonoidok, ellagtanninok, fenolos savak és ezek származékai (Najda, Dyduch-Sieminska et al. 2014, Del Bubba, Checchini et al. 2012). Az elsődleges fenolos vegyületek az erdei szamócában a kávésav, ellagsav és a tanninok. Az ellagsav és a kávésav védő hatását már korábban vizsgálták diabéteszes egerekben. Az egerek 2,5\% vagy 5\% kávésav, ellagsav diétát kaptak 12 héten keresztül. Az eredmények azt mutatták, hogy az alkalmazott kávésav és ellagsav mérsékelte a megnövekedett vesefunkció értékeket, csökkentette a plazma glükóz és Hemoglobin A1c (HbA1c) szintjét, és növelte a plazma inzulin szintjét. Más források szerint hasznos lehet a megelőzésben vagy a kiegészítő kezelésben a diabétesz okozta vesebetegségekben (Chao, Mong et al. 2010). A gyógyászati felhasználásra a virágzás időszakában kell a levelet (folium Fragaria) gyüjteni. Mint a többi Rosaceae családba tartozó növénynél a tanninok a legfontosabb alkotók. A népi gyógyászatban a leveleket hasmenés, köszvény kezelésére és a reuma enyhítésére használják. A földieper levelek alkalmazhatók még gargarizáló folyadékok és szájhigiéniás készítmények alkotórészeként is.

\subsection{Fahéjfa (Cinnamomum verum)}

A gyógyászatban felhasznált fahéj két, a Lauraceae családba tartozó faj, a Cinnamomum zeylanicum Nees (syn. C. verum J. S. Presl. ceyloni fahéjfa) és a $C$. cassia Blume (syn. C. aromaticum Nees, kasszia fahéjfa) drogja. A C. zeylanicum Indiában és Ceylon szigetén őshonos, közepes méretü örökzöld fa. A gyógyászatban használatos, ceyloni fahéjfa kéreg (Cinnamomi cortex Ph. Hg. VIII.) a fa ágairól lefejtett kéreg. A drog jellemzően füszeres illatú, édeskés, csípős ízü. A ceyloni fahéj mellett a kasszia (kínai) fahéj is forgalomban van. A ceyloni fahéj színe világosabb, mint a kínai fahéjé. A Dél-Kínában honos, gyakran 10 méter magasságot is elérö Cinnamomum cassia kérgéből nyert olaj (Cinnamomi cassiae aetheroleum, magyar nevén kasszia fahéj olaj) a VIII. Magyar Gyógyszerkönyv hivatalos drogja. A fahéjfa kérge 1- 
4\% illóolajat tartalmaz, amelynek 75-95\%-a (C. zeylanicum), illetve 64-76\%-a (C. cassia) fahéj aldehid, a többi komponens kis mennyiségben transz-fahéjsav, benzaldehid, eugenol (5-10\% $C$. zeylanicum, csak nyomokban a C. cassiában), kumarin $(0,45 \%$ C. cassia $), O$-metoxifahéjaldehid (C. zeylanicum). A fahéjat elsősorban emésztési zavarokban enyhe emésztőrendszeri görcsök, teltségérzet, felfúvódás és étvágytalanság esetén használják a tradicionális gyógyászatban. A ceyloni fahéjfa kéreg olajának antibakteriális és gombaellenes hatását in vitro kísérletekkel igazolták. A ceyloni fahéjfa kéreg olajának simaizom görcsoldó aktivitását, állatkísérletekkel bizonyították. Újabb állatkísérletes eredmények szerint a fahéjfa kéreg kivonata csökkenti a vércukorszintet, ebben szerepe lehet a drog amiláz gátló hatásának (Ph. Hg. VIII: European Pharmacopoeia; Magyar Gyógyszerkönyv. , Kim, Hyun et al. 2006). A fahéj vércukorszint-csökkentő hatását az elmúlt években egészséges egyéneken, 1-es és 2-es típusú cukorbetegségben is vizsgálták (Beejmohun, Peytavy-Izard et al. 2014).

\subsection{Szegfüszegfa (Syzygium aromaticum)}

A Syzygium aromaticum (L.) Merill et L. M. Perry (syn. Eugenia caryophyllus (C. Spreng.) Bull. et Harr.) 12-15 méter magas, örökzöld, a Myrtaceae családba tartozó növény. A szegfüszeget (Caryophylli flos Ph. Hg. VIII.) a bimbók szolgáltatják, amelyek jellegzetes barna színüket a szárítás során nyerik el. A szegfüszegből vízgőz-desztillációval előállított illóolaj (Caryophylli floris aetheroleum $\mathrm{Ph}$. Hg. VIII.) tiszta, sárga folyadék.

Az illóolaj fő komponense az eugenol (75-88\%), emellett eugenil-acetátot (4-15\%), valamint $\alpha$ - és $\beta$-kariofillént (5-14\%) is tartalmaz. A szegfüszeget mindig is gyógyhatású füszerként tartották számon. Tradicionális alkalmazásai között belsőleges (diszpepszia, láz) és külsőleges (fogínyvérzés ecsetelése) javallatok is találhatóak. A szegfüszeg kivonata in vitro bakteriosztatikus hatásúnak bizonyult számos törzs ellen, valamint gombaellenes hatását is kimutatták. A drog in vitro és állatkísérletes modelleken is mutatott gyulladáscsökkentő hatást (d'Avila Farias, Oliveira et al. 2014). Illóolaja görcsoldónak bizonyult. Vizsgálattal igazolták a szegfüszegolaj fájdalomcsillapító hatását fejfájás, illetve mozgásszervi fájdalom esetén. Kivonatának $\alpha$-amiláz- és $\alpha$-glükozidáz gátló hatását is kimutatták (Adefegha, Oboh 2012). 


\subsection{Babér (Laurus nobilis)}

A nemes babér (Laurus nobilis) a Földközi-tenger térségében honos örökzöld fa, amelynek levelét és termését füszerként hasznosítják ezen kívül külsőleg ízületi panaszok elleni felhasználását érdemes megemlíteni. A babérlevél bizonyítottan csökkenti a vércukorszintet (Khan, Zaman et al. 2009) ugyanakkor a vércukorszint csökkentő hatásmódja és hatóanyaga nem teljesen tisztázott. A hatásban ugyanakkor feltehetőleg jelentős szerepet játszik a növény illóolajának a-glükozidáz gátló hatása (Sahin Basak, Candan 2013).

\subsection{Amerikai tőzeg áfonya (Vaccinium macrocarpon )}

Alacsony termetü cserje, 15-30 centiméter felemelkedő, elágazó szárakkal. A levelek télen is zöldek, szórt állásúak, 2-3 centiméter hosszúak, tojásdad alakúak, kissé bőr neműek, merevek, élük visszahajtott és ritkásan csipkézett. A levelek fonákján barnás pontok láthatók, erezetük szárnyas. A virágok a szárak csúcsán tömörülnek, fehérek vagy vöröses rózsaszínűek, alakjuk csengettyüre emlékeztet. Májustól júniusig virágzik. A termés gömbölyü, vörös bogyó, átmérője 0,4-0,5 centiméter íze savanykás, kesernyés. Különböző szív- és érrendszeri megbetegedések, a cukorbetegség, a makula degeneráció és a szürke hályog kialakulásának megelőzésére használják. A 2-es típusú cukorbetegséggel, metabolikus szindrómával vagy inzulinrezisztenciával diagnosztizált betegek számára ajánlják a vércukorszint csökkentésére (Mathison, Kimble et al. 2014, Sun, Liu et al. 2016).

\subsection{Tea (Camellia sinensis)}

A teacserje, latin nevén Camellia sinensis L. (syn. Thea sinensis L.) levelét a gyógyászatban és az élelmiszeriparban is elterjedten használják. Dél-Kínában és Indiában őshonos. Két változatát termesztik: a var. sinensis-nek lándzsa alakú, 8-10 centiméter hosszú levelei vannak, a var. assamica-nak nagyobbak és hosszant hegyesedőek a levelei. A teacserje levele legnagyobb mennyiségben fekete- vagy zöld teaként kerül forgalomba. A kiindulási nyersanyag tehát ugyanaz, a megjelenés-, íz- és zamatbeli különbség az eltérő feldolgozási módnak tulajdonítható. A zöld tea előállítása során a friss tealeveleket megpörkölik, ami 
hatástalanítja a bennük található enzimeket, ezért leáll a tea tartalomanyagainak enzimatikus átalakulása, lebomlása. A fekete tea előállításánál ugyanúgy friss tealevelekből indulnak ki, de pörkölés helyett fermentálják a növényi nyersanyagot, amelynek eredményeként változik az aroma és a szín. A zöld és fekete tea között tehát nemcsak íz, hanem cserzőanyag-tartalom szempontjából is különbség van. A zöld tealevél jelentős mennyiségü 25-30\% cserzőanyagot is tartalmaz, a fekete tea ezzel szemben csak mintegy 5\%-ot. A teát a tradicionális keleti gyógyászatban gyógynövényként számos betegség kezelésére is alkalmazták. Tradicionális felhasználási céljai közé tartozott az élénkítés és a hasmenés csillapítása is. A tea és a benne található koffein stimuláns, vizelethajtó hatását számos humán vizsgálatban igazolták. A rendszeres, nagy mennyiségü (5-10 csésze naponta) zöld tea fogyasztás bizonyos emésztőszervi daganatok megelőzésében betöltött szerepét epidemiológiai vizsgálatok is alátámasztották. A teakivonat hasmenés gátló és daganatellenes hatását állatkísérletes modellben és humán vizsgálatokban is igazolták. A hatásban nagy szerepe van a legnagyobb mennyiségben jelen lévő cserzőanyag típusú vegyületnek, az epigallokatechin-3-gallátnak. Ugyanez a vegyület az $\alpha$-amilázt és az $\alpha$-glükozidázt is erősen gátolja (Gao, Xu et al. 2013). 


\section{Célkitüzés}

Napjainkban a 2-es típusú cukorbetegség az egyik leggyakrabban előforduló civilizációs betegség, melynek eredményes kezelésére kiváló lehetőséget nyújthat a természetes, növényi kivonatok alkalmazása. Ezen lehetőség gyakorlati megvalósítását elősegítendő doktori munkám céljai a következők voltak:

1. Különböző, bioaktív komponenseket tartalmazó gyógynövény-kivonatok készítése és in vitro antidiabetikus hatásaik tanulmányozására

2. Új HPLC alapú mérési módszer kidolgozása az $\alpha$-amiláz aktivitás in vitro méréséhez.

3. A kiválasztott növényi kivonatok sejtekre gyakorolt hatásának vizsgálata sejtvonalakon.

4. A növényi kivonatok lehetséges hatóanyagainak feltérképezése tömegspektrometriás vizsgálatokkal.

5. Az extraktumok in vivo tesztelése STZ indukált és HFHS diétán kezelt egérmodellekben. 


\section{$7 \quad$ Anyagok és módszerek}

\subsection{A vizsgált növények}

Az 1.táblázatban szereplő növényekre az amiláz-gátlás vizsgálatát végeztük el, a további vizsgálatokhoz pedig az erdei szamóca, áfonya és szeder növényekből egyenlő arányú keveréket készítettünk, amelyekkel az in vivo vizsgálatokat végeztük el.

1. táblázat A vizsgált növények listája

\begin{tabular}{|l|l|l|l|}
\hline \multicolumn{2}{|l|}{ Növények } & Latin név & \multirow{2}{*}{ Forrás } \\
\cline { 1 - 3 } Név & Laurus nobilis & levél & \\
\hline babérlevél & Cinnamomum zeylanicum & kéreg & Fitodry Kft \\
\hline ceyloni fahéj & Syzygium aromaticum & bimbó & Fitodry Kft \\
\hline szegfüszeg & Vaccinium macrocarpon & gyümölcs & Fitodry Kft \\
\hline amerikai tőzegáfonya & Camellia sinensis & levél & Gyógyfü Kft \\
\hline zöld tea & Rubus fruticosus & levél & Fitodry Kft \\
\hline szeder & Fragaria vesca & levél & Gyógyfü Kft \\
\hline erdei szamóca & Vaccinium myrtillus & levél & Fitodry Kft \\
\hline áfonya & & & \\
\hline
\end{tabular}

\subsection{Minta előkészítési lépések}

\subsubsection{A nyers extraktumok készítése}

A növényeket a Fitodry Kt.-től (Tiszaföldvár, Magyarország), a Gyógyfü Kt.-től (Sóskút, Magyarország) és a Herbária Zrt.-től (Budapest, Magyarország) vásároltuk meg. Először a száraz növényeket mechanikusan megdaráltuk (Kenwood AT320A EU) majd a pontosan 3,0 gramm mennyiséget $300 \mathrm{ml}$ vízben 20 percig forraltuk, majd szobahőmérsékletre hütöttük. Az így elkészített teát szürőpapíron leszürtük. Ezután a szürletet lefagyasztottuk -30 ${ }^{\circ} \mathrm{C}$-ra majd 36 óráig liofilizáltuk (Christ Alpha 1-4, Martin Christ GmbH. Osterode am Harz, Németország). Az erdei szamóca, áfonya és szeder növények liofilizált szilárd mintáiból egyenlő súlyarányú keveréket képeztünk, amit az in vivo kísérleteknél használunk. 


\subsubsection{Tannin mentesítés}

Az erdei szamóca, áfonya, szeder növényböl készült keverékből a tannin tartalmát és gátlóhatását szeretnénk igazolni ezért a növényi keverék mintából kivontuk a tannint. A tanninmentesítést marha albuminnal végeztük a következők szerint: 1,0 mg/ml marha szérum albumint $20 \mathrm{mM}$-os nátrium-acetát pufferbe oldottunk és a 10,0 $\mathrm{mg} / \mathrm{ml}$ növényi-vizes kivonatból készített oldatot 1:1 arányban kevertük 30 percig, ezután 10.000 rpm-el centrifugáltuk, és a felülúszóból elvégeztük a gátlási vizsgálatot az 7.3 fejezetben leírtak szerint (McArt, Spalinger et al. 2006).

\subsection{A növényi extraktumok hatása a glikozidhidroláz enzimekre}

\subsubsection{Az amiláz-aktivitás mérése}

\subsubsection{CNP-G7 szubsztrát szintézise és tisztítása}

A CNP-G7 szubsztrátot kémiai szintézissel állítottuk elő. A szintézis során az oligoszacharid peracetilezett származéka keletkezik, amelyből a Zemplén-féle dezacetilezéssel állítottuk elő a szabad oligoszacharidot. A további tisztítási műveleteknél 1,0 g CNP-G7-t feloldottuk $30 \mathrm{ml}$ metil-alkoholban (MeOH, VWR, Magyarország) majd $300 \mu 1$ 30\% nátriummetilátot (Merck, Magyarország) adtunk az oldathoz. A reakcióelegyet $0{ }^{\circ} \mathrm{C}$-on 50 percig kevertettük majd az oldószert csökkentett nyomáson bepároltuk és a maradékot vízben visszaoldottuk és Amberlite- $\mathrm{H}^{+}$gyanta (Sigma, Magyarország) hozzáadásával pH 6-ra savanyítottuk. A gyantát szüréssel távolítottuk el és a szürletet liofilizálással szárítottuk. A terméket desztillált vízben feloldottuk és szemipreparatív HPLC segítségével választottuk el a szabad klór-nitrofeniltől, amely a kész szubsztrát spontán degradációja során keletkezik. Ehhez szemipreparatív HPLC berendezést (Younglin 6400, Korea) használtunk, ami kézi mintaadagolóval UV/VIS detektorral és gáztalanítóval volt felszerelve. Állófázisként Supelcosil ${ }^{\mathrm{TM}}$ LC-18 (200 mm x $10 \mathrm{~mm}, 5 \mu \mathrm{m}$, Bellefonte, USA) oszlopot alkalmaztunk. A mozgó fázis $\mathrm{MeCN}$ : víz (10:90) arányú keveréke volt, áramlási sebessége 5,0 $\mathrm{ml} / \mathrm{min}$. A detektálást $302 \mathrm{~nm}$ (termék) illetve $400 \mathrm{~nm}$ ( $p$-nitrofenol) hullámhosszon végeztük, az injektálási térfogat $500 \mu \mathrm{l}$ volt. A szemipreparatív HPLC eljárással tisztított terméket ezután $50 \mathrm{C}^{\circ}$-ra fagyasztottuk és Christ Alpha1-4 liofilizáló készülékkel fagyasztva szárítottuk 36 órát. 


\subsubsection{A szubsztrát tisztaságának ellenőrzése és az enzimreakció utáni termékek mérése HPLC készülékkel}

A tisztított CNP-G7 szubsztrát tisztaságát folyadékkromatográfiás technikával vizsgáltuk. Az analitikai HPLC mérést (Agilent 1260 Infinity, Santa Clara, USA) kvaterner pumpával, vákuumos gáztalanítóval és kézi mintaadagolóval felszerelt rendszeren végeztük. A mérés UV/VIS detektorral ( $\lambda=302 \mathrm{~nm}$ ) történt Genesis C-18 (Berkshire, Anglia) $150 \mathrm{~mm}$ x 4,6 mm, $4 \mu \mathrm{m}$ oszlopon. A mozgó fázis MeCN és víz (15:85) keveréke volt. Az áramlási sebesség $0,8 \mathrm{ml} /$ perc, míg az injektált térfogat $20 \mu 1$ volt. A tisztaság megállapításánál a szubsztrát csúcsának területét viszonyítottuk a teljes csúcsterülethez. A rendszer vezérlését és az adatok kiértékelését a ChemStation B.04.03 (Agilent, USA) szoftverrel végeztük.

\subsubsection{Az optimális szubsztrát koncentráció meghatározása}

Az enzimreakció sebességét a szubsztrát koncentráció függvényében meghatároztuk. Az optimális szubsztrát koncentráció meghatározásához $400 \mu \mathrm{l}$ 1,0 mM, 2,0 mM, 3,0 mM, 4,0 mM, 5,0 mM, 6,0 mM CNP-G7 oldatokat keverünk össze $8 \mu 184$ nM HSA-val és a mintákat $37^{\circ}$ C-on inkubáltuk 5, 20, 35, és 50 percig. Az elválasztástechnikai méréseket a 7.3.1.2 fejezetben leírtak szerint végeztük. A különböző időpontokban injektált minták kromatogramján a CNP-G3-hoz tartozó csúcs területét mértük és ábrázoltuk az idő függvényében. A reakciósebesség meghatározása a CNP-G7-HSA katalizálta hidrolízis reakcióban az $\mathrm{y}=\mathrm{mx}(\mathrm{x}=$ terület $(\mathrm{CNP}-\mathrm{G} 3) ; \mathrm{y}=\mathrm{idő} \mathrm{(perc);} \mathrm{m}=$ reakciósebesség, terület/perc) egyenlet segítségével történt. Az enzim kinetika meghatározásához a Michaelis és Menten által kidolgozott, a reakciósebesség szubsztrát koncentráció függését leíró egyenletét alkalmaztuk, mely máig használatos az enzim-szubsztrát interakciós folyamatok jellemzésére. A $K_{M}$ az ún. Michaelis-Menten állandó, amely formálisan annak a szubsztrát-koncentrációnak felel meg, amelynél a reakció sebessége a $V_{\max }$ felével egyenlő. Ha a szubsztrát koncentrációja nagyon magas, akkor minden enzimmolekula enzim-szubsztrát komplex formájában lesz jelen, hiszen amint a termék ledisszociál az enzimről, a szubsztrát azonnal hozzákötődik. Ebben az esetben a reakció eléri a lehetséges maximális sebességet, a $\mathrm{V}_{\max }$-ot. A maximális sebesség egy adott enzimkoncentrációnál az átalakulás sebességi állandójától, a kcat katalitikus állandótól függ. A 


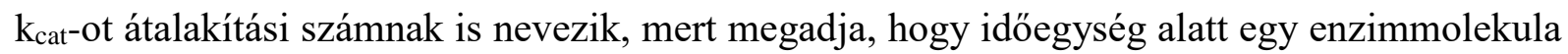
hány molekula szubsztrátot alakít át termékké (Elődi 1980).

A Michaelis-Menten paraméterek meghatározásához a HPLC méréssel különböző szubsztrát koncentráció $[\mathrm{S}]$ mellett kapott reakció sebességeket ábrázoltuk a szubsztrát koncentráció függvényében. Az adatok kiértékeléséhez a GraFit adatkiértékelő szoftvert használtunk.

\subsubsection{Az amiláz gátlás IC 50 értékének meghatározása}

Az inhibitor azon értékét, amely $50 \%$-al gátolja az enzim aktivitását $\mathrm{IC}_{50}$ - értéknek nevezzük. Az eredeti 5,0 mg/ml-es extraktum törzsoldatokat hígítottuk 3 tízszeres hígítási lépcsőben és egyenként lemértük a gátlási viszonyokat három ismétlésben. Az adatokat nem lineáris regresszióval értékeltük (Amine, El Harrad et al. 2014), ahol az adatok kiértékeléséhez a GraFit szoftvert (http://www.erithacus.com/grafit/) alkalmaztuk. Az eredményeket az akarbózhoz viszonyított relatív gátlásban is megadtuk (Relatív gátlás $=\mathrm{IC}_{50} / \mathrm{IC}_{50}$ akarbóz), ahol az akarbóz 5,0 mg/ml-es oldatából indult a hígítási sorozat.

\subsubsection{Az $\alpha$-glükozidáz gátlásának mérése}

Az $\alpha$-glükozidáz aktivitást standard módon határoztuk meg $10 \mu$ l glükozidáz enzim (10 E/ml) (EC 3.2.1.20) ( $\alpha$-Glucosidase Saccharomyces cerevisiae, Sigma) és $10 \mu$ növényi extraktum $(5 \mathrm{mg} / \mathrm{ml})$ alkalmazásával. Eppendorf csőben összekevertük és $30 \mu 1$ kálium-foszfát puffert (100 mM), $\mathrm{pH}=6,8$ a $37^{\circ} \mathrm{C}$ adtunk a keverékhez. Az első inkubálást pontosan 5 percig végezzük $37^{\circ} \mathrm{C}$-on és utána $400 \mu \mathrm{l}(5,0 \mathrm{mM}) p$-nitrofenil- $\alpha$-D-glükozid szubsztrátot adtunk hozzá. A keletkezett színes termék abszorbancia-változását kinetikusan mértük spektrofotométerrel (Teco Neufahrn in Niederbayern, Németország) 405 nm-en. A kontrol mintákat a növényi extraktumok nélkül készítettük el. A gátlás mértékét százalékban határoztuk meg: Gátlás $\%=\left(\Delta \mathrm{A}_{\text {kontrol }}-\Delta \mathrm{A}_{\text {extraktum }}\right)$ x $100 / \Delta \mathrm{A}_{\text {kontrol, }}$, ahol $\Delta \mathrm{A}_{\text {kontrol }}$ a kontrol, $\Delta \mathrm{A}_{\text {extraktum }}$ az extraktum kinetikus abszorbancia értéke (Sindhu S )

$\mathrm{Az} \mathrm{IC}_{50}$ értékek meghatározásához a százalékos gátlást ábrázoltuk az extraktumok logaritmikus koncentrációjának függvényében. Ehhez az eredeti 5,0 mg/ml-es extraktum 
törzsoldatokat hígítottuk $500 \mu \mathrm{g} / \mathrm{ml}, 50 \mu \mathrm{g} / \mathrm{ml}$ és $5 \mu \mathrm{g} / \mathrm{ml}$ koncentrációkban és egyenként lemértük a gátlási viszonyokat három ismétlésben. A gátlási értékek átlagára függvényt illesztve megkaptuk az $\mathrm{IC}_{50}$ koncentrációkat. Az akarbózt alkalmaztuk referencia $\alpha$-glükozidáz inhibitorként.

\subsection{Az antioxidáns kapacitás mérése}

Az antioxidáns kapacitás mérését fotokemilumineszcens (PCL) módszerrel, végeztük annak megállapítása céljából, hogy az aktív hatóanyagokat tartalmazó növényi kivonatoknak mennyi az antioxidáns kapacitása. Ezeket a komponenseket vízoldható frakciókban detektáltuk (Nekvapil, Kopriva et al. 2012). A méréseket a Photochem (Analytik Jena, Németország) készülékkel végeztünk, amely lehetővé teszi a vízoldható antioxidáns kapacitás (ACW), mérését, amely arra szolgál, hogy meghatározzuk és számszerüsítsük az antioxidáns mennyiségét. A mérési elv azon alapul, hogy a szabad gyökök (szuperoxid gyökök) reagálnak egy hozzáadott indikátor vegyülettel, melyek optikai fény gerjesztés hatására fotonokat emittálnak, amit a detektor közvetlenül érzékel. A készülék a kalibrációs oldatsorozat segítségével kiszámítja, és számszerüsíti is a minta vízoldható antioxidáns kapacitását (ACW) aszkorbinsav ekvivalens egységben. A mérést a gyár által forgalmazott ACW Kit (Jena AG Company, Németország) készlettel végeztük a gyártó előírásai szerint amely a következőket tartalmazza: Reagens R1 hígító (minta oldószer); Reagens R2, reakció puffer; Reagens R3, fényérzékenyítő; Reagens R4, standard aszkorbinsav. A minták előkészítéséhez $10 \mu 1$ mintát elegyítettünk $1500 \mu 1 \mathrm{R} 1$ reagenshez és hozzáadtunk $1000 \mu 1 \mathrm{R} 2$ reagenst. A reakcióelegyet Vortex keverővel kevertük, majd hozzáadunk $25 \mu 1$ R3 reagenst, majd ezt követően mértük a Photochem készülékkel. A minták mérése során három párhuzamos mérést végeztünk. Az antioxidáns kapacitást aszkorbinsav ekvivalens értékben adtuk meg, vagyis $1 \mathrm{mg} C$-vitamin antioxidáns hatásához viszonyítva állapítottuk meg a hatást és $(\mu \mathrm{g} / \mathrm{mg})$ egységben fejeztünk ki.

\subsection{MALDI-TOF vizsgálatok}

A szintetizált szubsztrát tisztaságának ellenőrzéséhez és az erdei szamóca, áfonya és szeder extraktumok tartalmának vizsgálatához a tömegspektrometriás méréseket egy MALDITOF (Matrix Assisted Desorption/Ionization- Time Of Flight) készülékkel végeztük. A mérésekhez egy Bruker Biflex III, reflektronnal és „,delayed extraction”-nal felszerelt tömeg 
spektrométert használtunk. A mérésekhez mátrixként 2,5-dihidroxibenzoesavat (2,5-DH, Sigma-Aldrich Chemie GmbH München, Németország) alkalmaztunk és pozitív-ion módban végeztük a méréseket. A mintában lévő molekulák gázfázisba juttatását, deszorpcióját/ionizációját nitrogén lézerrel 377 nm-en végeztük az ionforrásban, ahol az impulzusszerủen előállított ionok a gyorsító feszültség hatására belépnek az erőtérmentes repülési csőbe és a fajlagos tömegük alapján elkülönülnek. A lézerhez $19 \mathrm{kV}$ a gyorsítóhoz pedig $20 \mathrm{kV}$ reflektron feszültséget alkalmaztunk és a spektrumokat 100 darab lézer lövésével vettük fel. A kapott tömegspektrumok kiértékelését, a készülék X-TOF programjával végeztük. Az azonosításhoz a Metabolomics Workbench (http://www.metabolomicsworkbench.org/) adatbankját használtuk.

\subsection{Sejtes hatásvizsgálatok}

\subsubsection{Valós idejü citotoxicitási teszt H9c2 sejteken}

A kísérletekhez használt H9c2 (patkány embrió szív/miokardium) sejtvonalat (ATCC, USA) $10 \%$ FBS-el (Fetal Bovine Serum, magzati borjú szérum, Sigma-Aldrich Kft Budapest Magyarország) $100 \mathrm{U} / \mathrm{ml}$ penicillinnel (Sigma-Aldrich Kft Budapest, Magyarország), 100 $\mu \mathrm{g} / \mathrm{ml}$ sztreptomicinnel (Sigma-Aldrich Kft Budapest, Magyarország) és 4 mM L-glutaminnal (Sigma-Aldrich Kft., Magyarország) kiegészített DMEM (Dulbecco's Modified Eagle's Medium, Sigma-Aldrich Kft Budapest Magyarország) tápközegben tartottuk fenn $100 \mathrm{~mm}$ átmérőjű sejttenyésztő edényekben (Orange Scientific, Braine-l'Alleud, Belgium) $37{ }^{\circ} \mathrm{C}$-on. A sejtes toxicitási méréseket 96 mintahelyes mikrotiterlapokon végeztük, ahol 6000 H9c2 sejtet helyeztünk az egyes mintahelyekre. Egy éjszakán át tartó inkubációt követően a sejteket a növényi extraktumokból készült hígítási sorral kezeltük (1, 10,100, $1000 \mathrm{mg} / \mathrm{ml})$. A kezelések után, 24 és 48 h múlva a sejtek életképességét a kolorimetriás MTS (3-(4,5-dimetiltiazol-2-il)5-(3-karboximetoxifenil)-2-(4-sulfofenil)-2H-tetrazólium, Promega Madison, USA) vizsgálattal mértük a gyártó elöírásai szerint. Az életképességet a DMSO-hoz, mint technikai kontrolhoz viszonyítottuk. Minden mérést három ismétlésben végeztünk el, amelyekből megállapítottuk az átlagértékeket és a szórást. 


\subsubsection{Citoprotekciós kísérlet menete RTCA-SP rendszeren}

A citoprotekciós kísérleteket a 7.6.1 fejezetben leírtak szerint végeztük és a H9c2 sejteket alkalmaztunk. A valós idejü sejtéletképesség méréshez a Roche xCELLigence SP (ACEARoche, Budapest, Magyarország) készüléket használtuk, mely a sejtek vezetőképességének változása alapján ad információt a sejtek életképességéről (Ozsvari, Puskas et al. 2010). Az RTCES 96 lyukas E-lemezeket (Roche, Magyarország) 0,2 \%-os PBS-ben (Phosphate Buffered Saline, Sigma-Aldrich Kft., Magyarország) oldott zselatinnal lefedtük 20 percig $37^{\circ} \mathrm{C}$-on, majd a zselatint PBS oldattal kétszer mostuk. A sejtek növekedéséhez szükséges tápoldatból $50 \mu 1-t$ adtunk az E-lemezek mintahelyeibe, hogy fel tudjuk venni az RT-CES rendszerben a háttérzajt. A háttér jelérték felvétele után a mintahelyekbe $50 \mu$ sejtszuszpenziót adtunk, majd a lemezt 30 percig szobahőmérsékleten inkubáltuk steril körülmények között, majd ezt követően helyeztük az RT-CES készülékbe. A sejtek növekedését egy éjszakán keresztül monitoroztuk az elektromos ellenállás változásának mérésével 5 perces mintavételi intervallumokban. Az sejtek folyamatosan rögzített ellenállását Sejt Index (CI) értékben fejeztük ki a következők szerint: $\mathrm{CI}=($ az $\mathrm{n}$ pontban felvett ellenállás - a sejtek nélkül felvett ellenállás $) /$ várt ellenállás érték.

A következő napon a sejteket előkezeltük a növényi extraktumokkal, majd 30 perccel később a rendszerhez $\mathrm{H}_{2} \mathrm{O}_{2}$ oldatot adtunk. A sejtek sérülését okozó hidrogén-peroxid oldat koncentrációját minden vizsgálat előtt kalibráltuk $(500-900 \mu \mathrm{M})$. A kezelt és a kontroll sejtek elektromos ellenállásáról 5 percenként vettünk fel adatokat. Minden felvett nyers adatpontot a készülék normalizált az adott vizsgálati időpontban korábban felvett sejt index értékkel. Minden egyes tesztet három, az adott E-lemezen belüli ismétlésben folytattunk le.

\subsection{In vivo vizsgálatok}

\subsubsection{Magas zsír és szacharóz tartalmú prediabéteszes elhízás modell alkalmazása a hatástesztekben}

A magas zsír- és szacharóz tartalmú (HFHS) táplálék által előidézett prediabetikus elhízási modellt alkalmaztuk a 2-es típusú cukorbetegség tesztelésére. Ezeket a kísérleteket a hím C57BL6 egereken hajtottuk végre, amelyek hajlamosak a táplálék által kiváltott elhízásra. Az állatokat 5 hónapig 9-13 hetes koruktól kezdődően magas zsír- és szacharóz tartalmú 
étrenden (HFHS) tápláltuk. A standard készítményt kiegészítettük sertés zsírral és szacharózzal (58\% normál táp, 30\% szalonna, 12\% szacharóz). Ennek a tápanyagnak az energiatartalma 4,9 $\mathrm{kcal} / \mathrm{g}$ volt, és tartalmazott 7,4 \% fehérjét; 39,2 \% szénhidrát; 47,8 \% zsírt. A kontroll állatok standard rágcsáló tápot kaptak (VRF1) (Special Diets Services Witham, Essex, Anglia) amelynek az összetétele és energia tartalma a következő volt. Energia tartalom 3,4 kcal/g, 22,5 $\%$ protein, $65 \%$ szénhidrát, $12,6 \%$ zsírt.

\subsubsection{Streptozotocin indukált cukorbetegség}

A streptozotocin (STZ) emlősökben inzulin termelö pancreász béta sejtek számára mérgező, és súlyos cukorbetegséget okoz. A STZ-t (Sigma Aldrich Budapest, Magyarország) frissen feloldottuk $100 \mathrm{mM}$ nátrium-citrátban $(\mathrm{pH} 4,5)$, és intraperitoniálisan 200 mg/testtömeg-kilogramm (tstkg) dózist adtunk felnőtt hím CD1 egereknek. A kontroll állatok hatóanyag nélküli vivőanyagot kaptak. A STZ-indukálta cukorbetegséget a farok vénából vett vérminta alapján a kezelést követő ötödik napon határoztuk meg. A nem éheztetett $14 \mathrm{mM}$ feletti vércukorszinttel rendelkező egereket cukorbetegnek tekintettük.

\subsubsection{In vivo kísérleti tervezés}

Az akarbózt (Glucobay Bayer $A G$ Leverkusen, Németország), a kukoricakeményítőt (Haas, Győr, Magyarország) és a növényi kivonatokat frissen feloldottuk steril ivóvízben, és éhgyomorra adagoltuk per os (200 $\mu$ lállat). Az in vitro enzimgátlási kísérletek eredményei alapján az egyes növényi kivonatok liofilizált porából azonos mennyiséget kevertünk és in vivo alkalmaztuk. A normál (nem diabetikus), a pre-diabetikus (HFHS-diéta indukálta) és a cukorbeteg (STZ-kezelt) egereket véletlenszerüen csoportokra osztottuk (4-7 állat/csoport). A STZ- indukálta diabéteszes egereket kétszer vizsgáltuk, az STZ-kezelést követő 5. és 10. napon. CD1-es típusú állatokon végzett kísérletekben az egereket egy éjszakán át éheztettük. A C57BL6 egereken (HFHS táplált, pre-diabetikus és kontroll) végzett vizsgálatok során az állatokat 5 órán át éheztettük. Minden éheztetett állat számára szabad hozzáférést biztosítottunk a vízhez. Az éhezési periodust követően a hordozóanyagot (steril ivóvizet) vagy a keményítőt ( 1 g/tstkg) orális szondán keresztül adtuk be. Közvetlenül a hordozó- vagy keményítő kezelés 
után az állatok második alkalommal kapták az Akarbózt (10 mg/tstkg, pozitív kontroll) vagy növénykivonatot $(1200 \mathrm{mg} / \mathrm{tstkg})$. Vérmintákat vettünk a farok vénájából az orális kezelés után a 0.- 30.- 60.- 120.- és 180. percben. A vércukorszintet a DCont Personal Blood Glucose Meterrel (77 Elektronika Kft. Budapest, Magyarország) mértük. A növénykivonatok hatásos dózisának meghatározásához előkísérleteket végeztünk, amelyben a normál CD1 egereket egy éjszakán át éheztettük, és 1000 mg/tstkg keményítővel önmagában vagy 10, 200, 400, 600, 1200 és $1600 \mathrm{mg} /$ tstkg növénykivonattal vagy $10 \mathrm{mg} /$ tstkg Akarbózzal végeztünk. Minden eljárást az Európai Közösségek tanácsi irányelvei szerint (86/609 EGK) végeztük és összhangban, voltak, az Institutional Animál Care and Use Committee iránymutatásaival a protokollt jóváhagyta a Kísérleti Orvostudományi Kutatóintézet, Budapest, Magyarország (engedély száma: PEI / 001/35-4/2013).

\subsection{Statisztikai elemzés}

Minden adat átlagát \pm SEM fejeztük ki. A Kolmogorov-Smirnov normalitási vizsgálatot az egyirányú ANOVA-val, majd a Tukey-féle post hoc teszttel elemeztük. Az in vivo kísérletekben a csoportok közötti vércukorszint különbségeket többszörös t-teszttel elemeztük. A statisztikai analízist a GraphPad PRISM 6. verzió szoftver (GraphPad Software, USA) segítségével végeztük és az eltéréseket $\mathrm{p}<0,05$ esetén tekintettük szignifikánsnak. 


\section{Eredmények}

\subsection{A növényi extraktumok}

A növényi extraktumok készítése során az oldatok legtöbbször barna színűek voltak (babérlevél, fekete ribizli, ceyloni fahéj, szegfüszeg, szeder, erdei szamóca, áfonya) kivéve a zöld teát (sárga) és az amerikai tőzegáfonyát (vörös). Az utóbbi azonban a növény gyümölcséből készült, míg a többi extraktum föként a levélből, a fahéj és a szegfüszeg kivételével, mely a növény kérgéből, illetve a bimbóból készült. A növények nagyon eltérő kihozatallal rendelkeztek az alkalmazott eljárással extrahálható komponensek tekintetében. A 10 g-ból extrahálható anyagok mennyiségét mutatja be az (2. ábra). Az ábrán jól látszik, hogy a legnagyobb tömegủ extrahálható tartalommal a fahéj rendelkezett, míg a legkevesebb anyagot az áfonyából tudtuk extrahálni. Általánosságban elmondható, hogy 1,5 g és 4 g közötti tömegeket (15-40 \%) lehetett extrahálni a vizsgált növényekből.

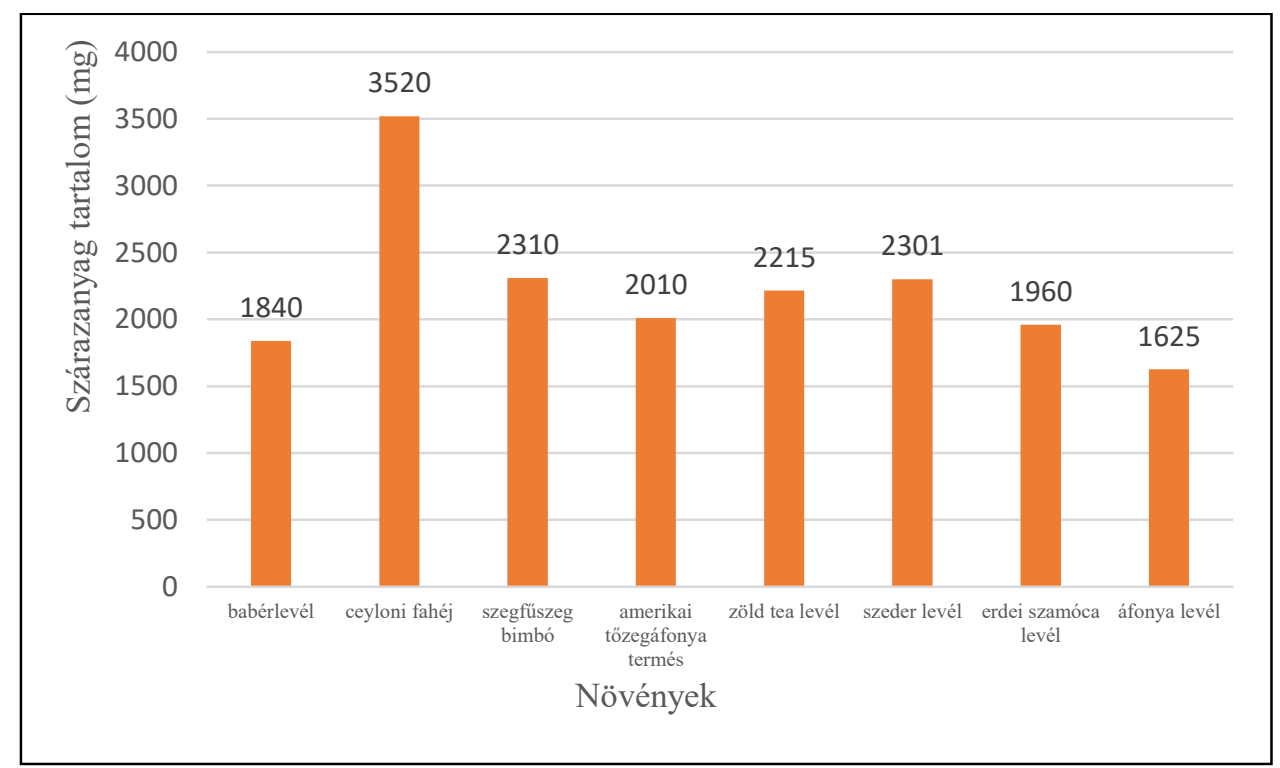

2. ábra A vizsgált növények 10 g-nyi mennyiségböl extrahálható anyagainak mennyisége 


\subsection{Az amiláz mérési eljárásának kidolgozása}

A HPLC kétségtelenül az egyik legfontosabb analitikai módszer a vegyületek azonosítására és mennyiségi meghatározására vakamint a HPLC-technikák használata az enzimatikus reakciók tanulmányozásában is jelentősen megnőtt. A HPLC alkalmazásával a komponensek elválasztása és mennyiségi meghatározása lehetséges és az adatokból a reakciók sebessége kiszámítható. Az általunk kidolgozott módszerben a szubsztrát és a három felszabaduló redukáló végtermék hasonló vegyület (maltooligomerek) és valamennyi tartalmaz kromofor csoportot, ezért a folyadékkromatográfiás gyakorlatban alkalmazott detektorokkal pl. (UV) jól mérhetőek.

\subsubsection{A CNP-G7 szintézis és a tisztítás ellenőrzése}

A tisztított CNP-G7 szubsztrát retenciós ideje 6,69 perc volt az alkalmazott elválasztás technikai körülmények között (3. ábra). A csúcsterületek alapján a minta tisztasága 96,92\% volt.

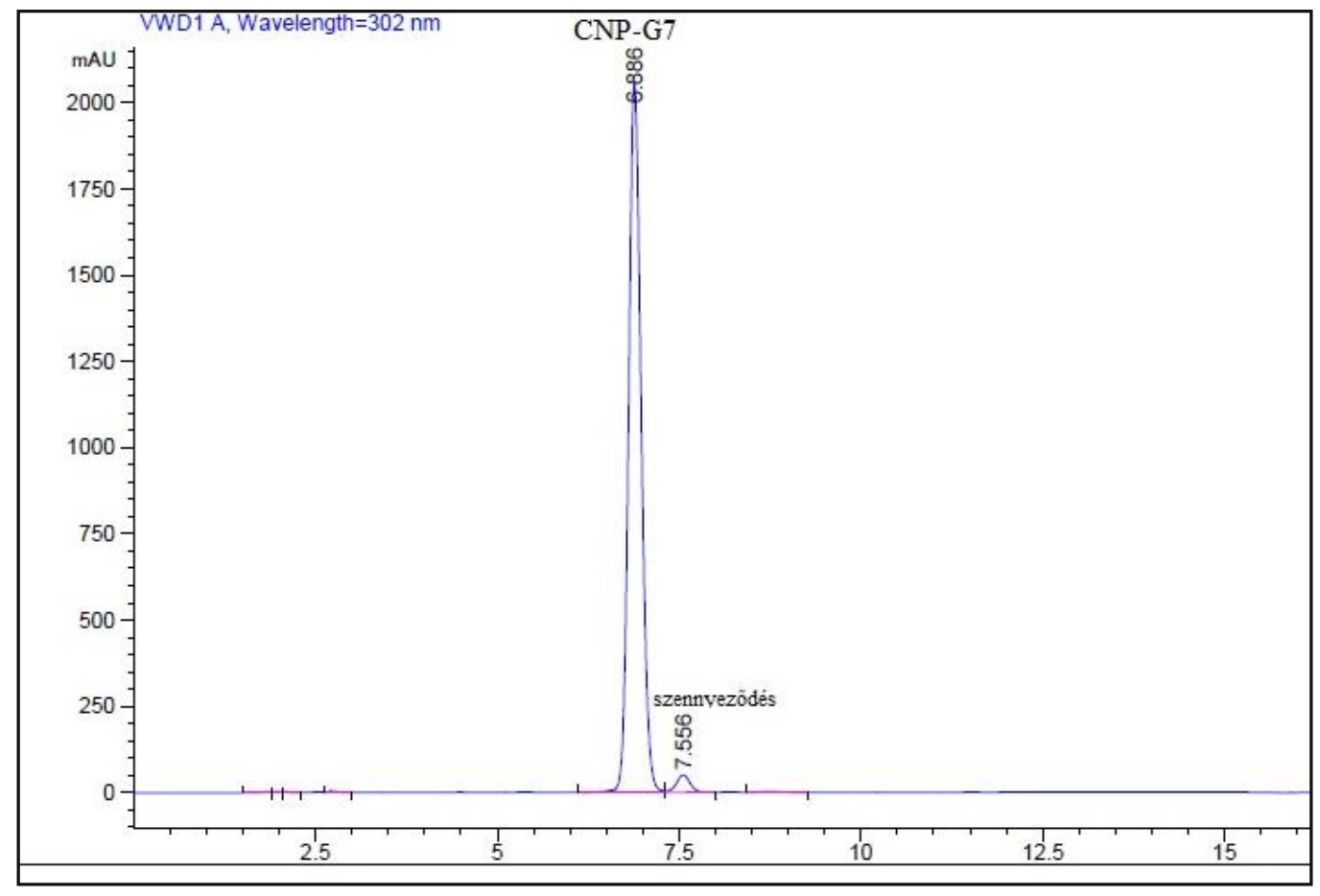

3. ábra Tisztított CNP-G7 szubsztrát HPLC kromatogramja 
A pozitív ionizációs módban felvett MALDI-TOF MS spektrumon (4. ábra) láthatjuk a CNP-G7 nátrium és a kálium addukt ionjait. A számított molekulatömeg a nátrium addukt esetében 1330,34 Da $\left[\mathrm{C}_{48} \mathrm{H}_{74} \mathrm{O}_{38} \mathrm{NCl}+\mathrm{Na}\right]^{+}$volt a kálium addukt esetében $1346,32 \mathrm{Da}$ $\left[\mathrm{C}_{48} \mathrm{H}_{74} \mathrm{O}_{38} \mathrm{NCl}+\mathrm{K}\right]^{+}$, míg a kis mennyiségü $\mathrm{G} 7$ oligomer is látható a spektrumon $1175,37 \mathrm{~m} / \mathrm{z}$ értéknél $\left([\mathrm{M}+\mathrm{Na}]^{+}\right)$, amely nem tartalmazza a kromofor csoportot.

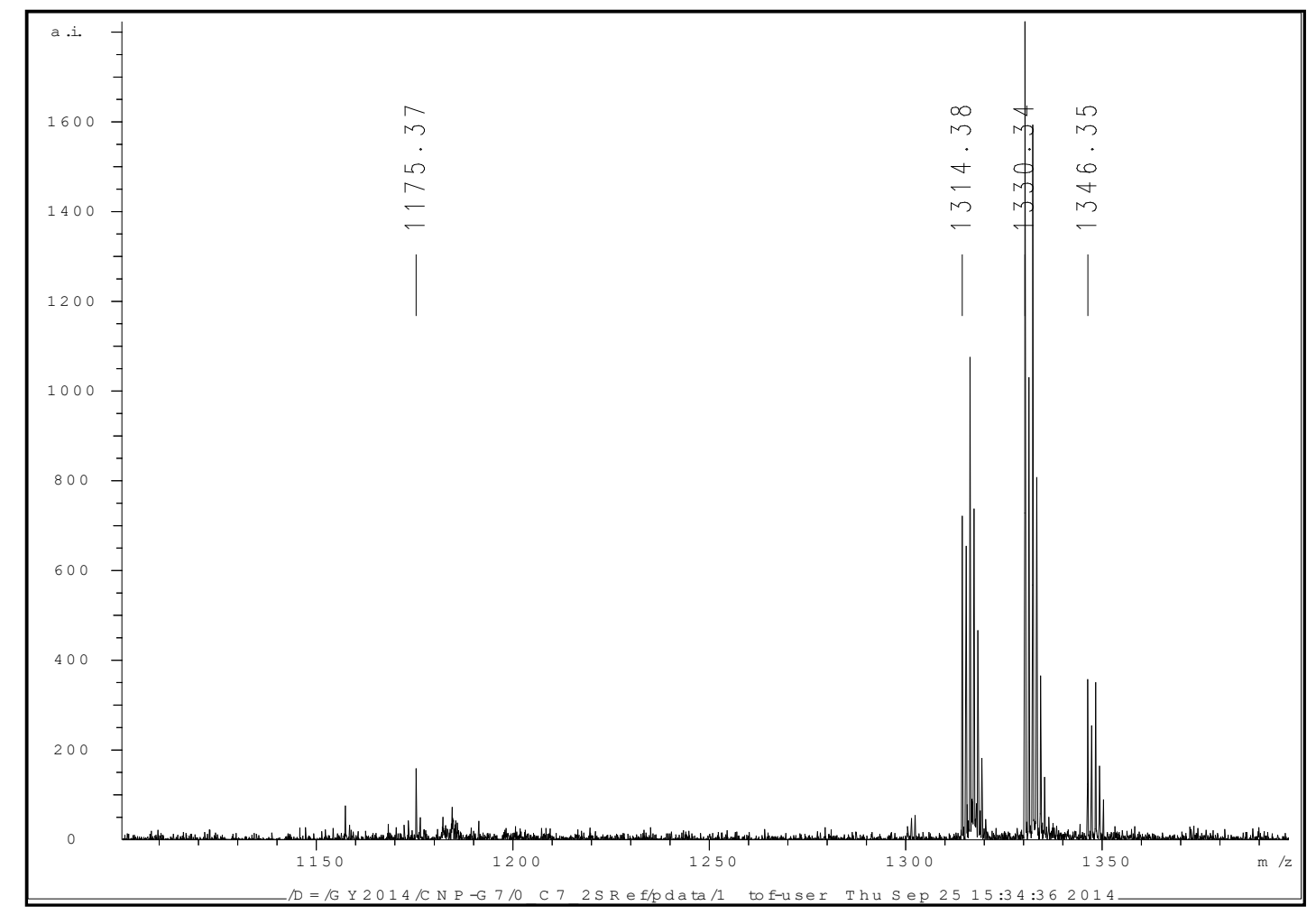

4. ábra CNP-G7 szubsztrát MALDI-TOF MS spektruma

\subsubsection{Az optimális szubsztrát koncentráció meghatározása}

A HPLC mérés segítségével különböző szubsztrát koncentráció [S] mellett kapott reakció sebességeket ábrázoltuk a szubsztrát koncentráció függvényében (5. ábra). Az adatokra nem-lineáris regresszióval, a Michaelis egyenlet felhasználásával görbét illesztettünk. Az így kapott telítési görbe alapján meghatároztuk a későbbi aktivitásmérésekhez az optimális szubsztrát koncentrációt, amit 5 mM-ban állapítottunk meg, mert ennél a koncentrációnál a szubsztrát koncentráció kismértékü változása már nem okozott jelentősebb sebesség változást. A további méréseket ezzel az $5 \mathrm{mM}$ [S] koncentrációval végeztük. 


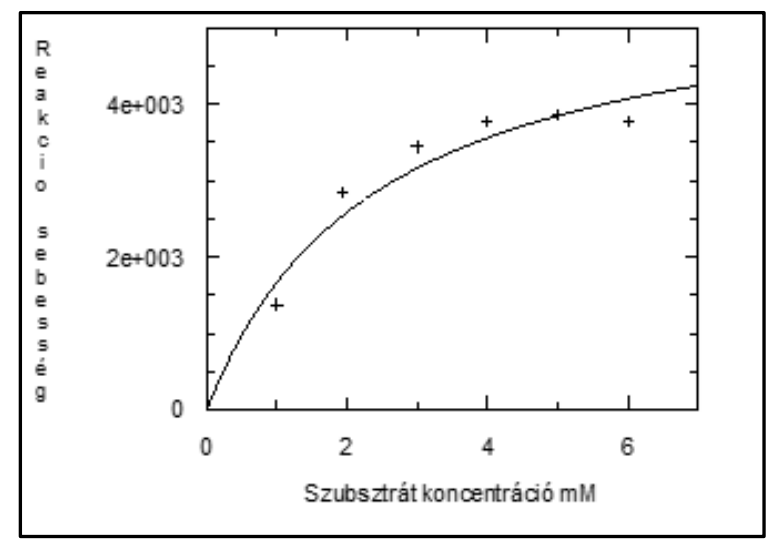

5. ábra A különböző szubsztrát koncentráció [S] mellett kapott reakció sebességek.

A Michaelis-Menten egyenletböl kapott enzim kinetikai adatok a következők: $\mathrm{V}_{\max }=$ 5712.3471 +/- 946.7714; $\mathrm{K}_{\mathrm{m}}=2.4151+/-1.0595$. Az elérhető legmagasabb $\mathrm{V}_{\max }$ sebességi értéket akkor kapjuk, ha az összes enzim ES komplexben van. Amennyiben az [S] értéke éppen megegyezik a $\mathrm{K}_{\mathrm{M}}$ számértékével, akkor a reakció a $\mathrm{V}_{\max }$ felének megfelelő sebességgel zajlik. A $K_{M}$ az ún. Michaelis-Menten állandó, ami formálisan annak a szubsztrát-koncentrációnak felel meg, amelynél a reakció sebessége a $\mathrm{V}_{\max }$ felével egyenlő. Minél kisebb a disszociációs állandó annál kisebb a $\mathrm{K}_{\mathrm{M}}$ és annál nagyobb az enzimreakció sebessége.

Az enzimaktivitás mérésekhez a tisztított CNP-G7 szubsztrátot használtuk, amely több produktív kötőmódot tud létrehozni a HSA aktív centrumával, ezért a kromatogramon három különböző hosszúságú termék keletkezett, melyeket HPLC módszerrel választottunk el egymástól és a szubsztráttól (6. ábra). A fő termék a CNP-G3 (7. ábra) keletkezésének a sebességét határoztuk meg, mely arányos az enzimaktivitással. A sebesség meghatározása úgy történt, hogy a különböző időpontokban injektált minták kromatogramján a CNP-G3 hoz tartozó csúcs területét mértük és ábrázoltuk az idő függvényében. A pontokra illesztett egyenes meredeksége adta meg a sebességet. A CNP-G3 csúcs alatti területe egyenesen arányos volt az enzimaktivitás változásával. Lehetett volna az összes képződött termék csúcsterületével is számolni, ami számértékileg nagyobb sebesség értékeket adott volna, de a tendenciák szempontjából ez nem jelentett különbséget. 


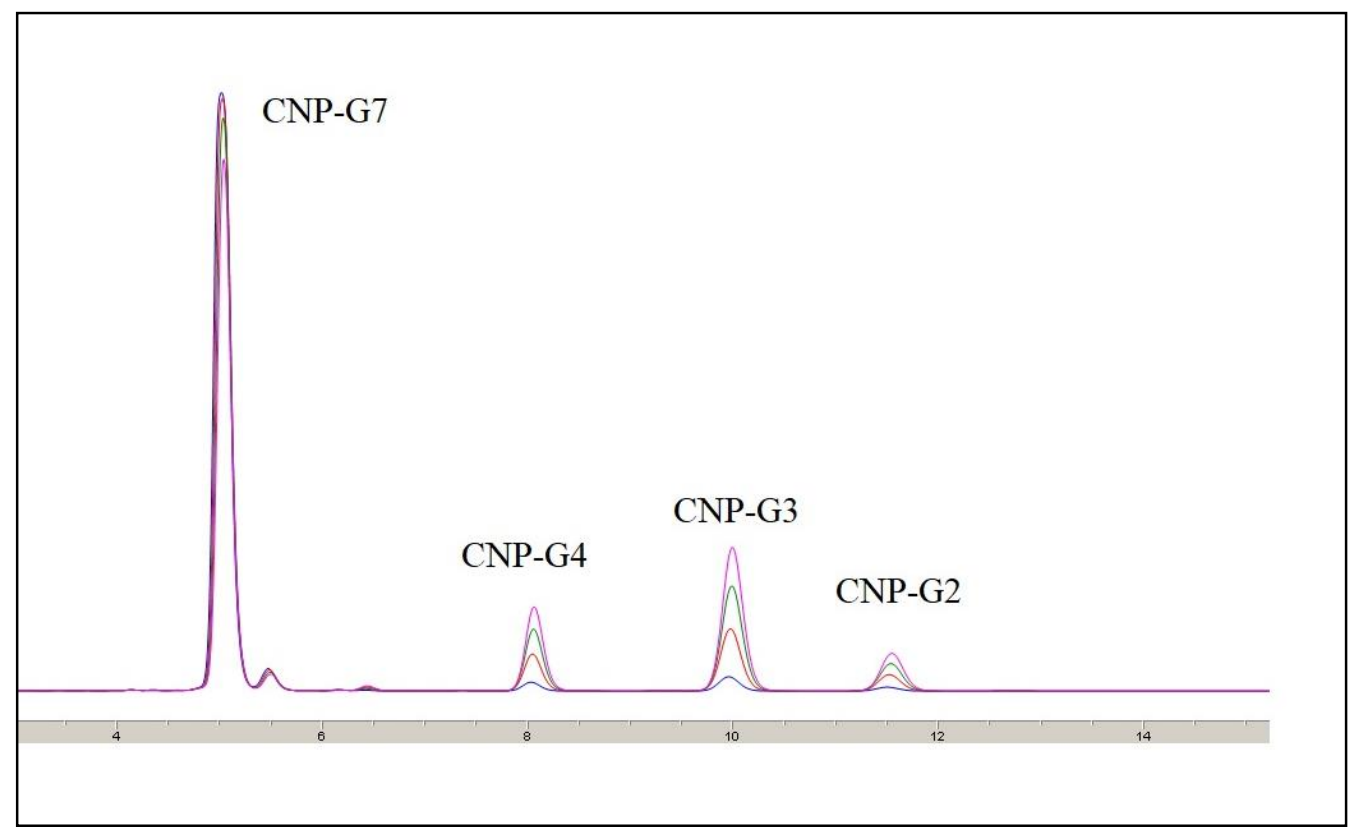

6. ábra A különböző időpontokban injektált minták kromatogramja

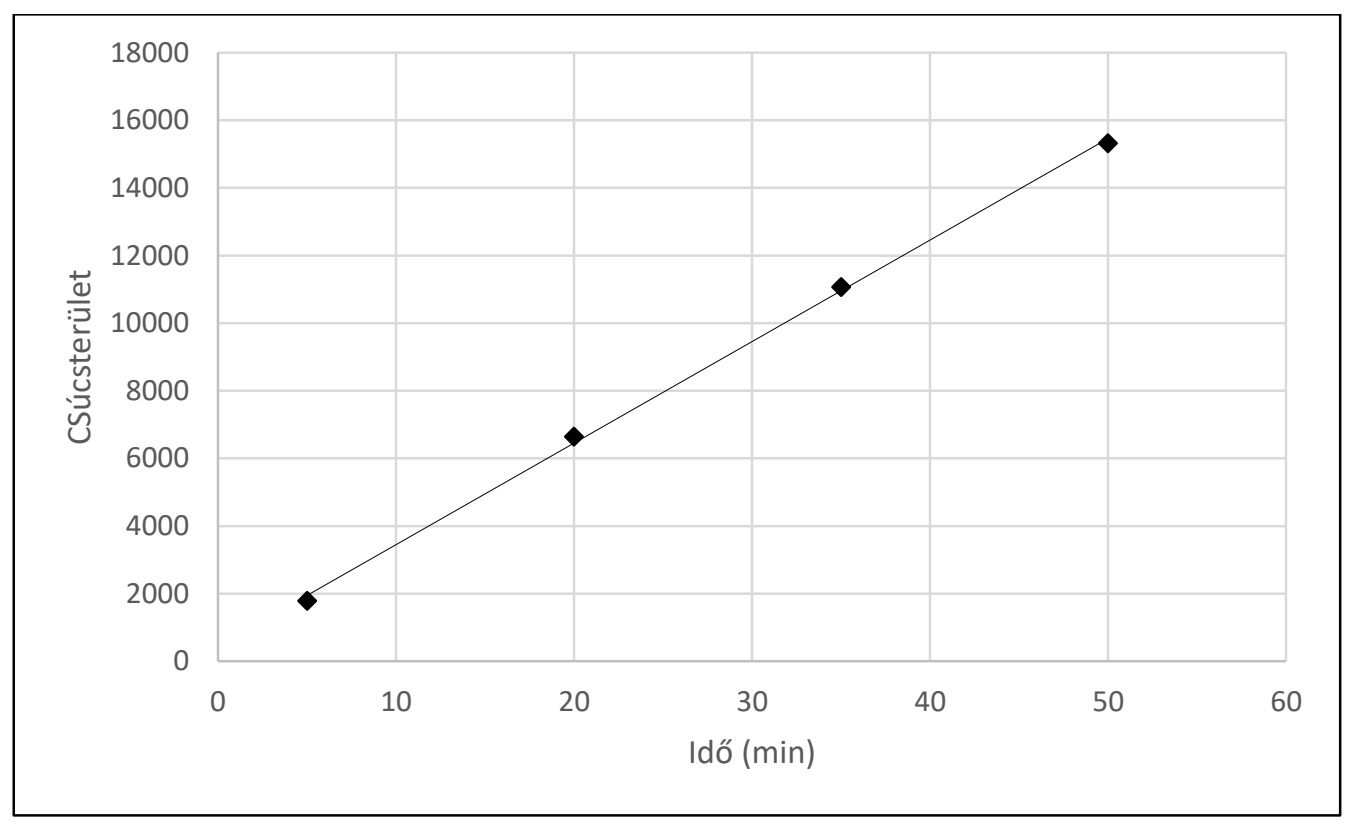

7. ábra A CNP-G3 képződés reakciósebességének meghatározása

A CNP-G3 képződés reakciósebességének meghatározása során a CNP-G7-HSA katalizálta hidrolízis reakcióban a sebességet ( $\mathrm{v}$ ) lineáris regresszióval határoztuk meg, $\mathrm{az} \mathrm{y}=\mathrm{mx}$ ( $\mathrm{y}=$ terület (CNP-G3); $\mathrm{x}=$ idő (perc); m= reakciósebesség terület/perc) egyenlettel. Az egyenes egyenlete $y=300,23 x+454,13$ volt, és a korrelációs koefficiens pedig $R^{2}=0,999$ volt. 
A mérési módszer kidolgozása során mindenképpen szükséges volt elválasztás technikai megközelítést alkalmazni, mert a termékeket a szubsztráttól függetlenül nem lehet más módon detektálni. A szubsztrátból ebben az esetben rövidebb oligoszacharidok keletkeznek, ahol a kromofor csoportok mindvégig a termékeken maradnak, amit a HPLC-vel el tudtunk választani. A fotometriás módszereknél segéd enzimeket is alkalmaznak a szabad kromofor lehasítására a hasonló oligomer szubsztrátról, és így a felszabaduló kromofor koncentrációját határozzák meg. Ezzel az aktivitás mérési módszerrel a gátlások vizsgálatánál az a probléma, hogy a hasonló hatásmechanizmusú glikozidáz segédenzimeket is gátolhatja az inhibitor. Ebben az esetben nehéz eldönteni, hogy csak az amiláz vagy a glükozidázokra gyakorolt gátlás hatását is észleljük (Lorentz 1998). A CNP-G7 szintézisénél kialakított $\beta$ konfiguráció megvédi a kromofor csoportot az amiláz hasításától így az mindvégig a szubsztráton marad specifikussá téve a meghatározást. Az általunk alkalmazott szubsztráttal és az új HPLC eljárással csak a valós $\alpha$-amiláz gátlást detektáljuk, ami független a más glikozidázok aktivitásától.

\subsection{A növényi extraktumok hatása a glikozid-hidroláz enzimekre}

\subsubsection{Az extraktumok amiláz gátló hatása}

A táblázatban (2. táblázat) a kivonatok és az akarbóz kontroll gátlási eredményei láthatóak. A mérések alapján kijelenthető, hogy minden vizsgált extraktum magasabb $\mathrm{IC}_{50}$ értékkel rendelkezett, mint a kontroll vegyület. A leghatástalanabb az amerikai tőzegáfonya volt, míg a legígéretesebb $\mathrm{IC}_{50}$ értéket a fahéj mutatta. Ez utóbbi gátlása háromszoros volt az akarbózhoz viszonyítva. A további vizsgálatokhoz három Európában is őshonos növény került kiválasztásra (erdei szamóca, áfonya és szeder), mert kedvező biológiai hatások esetén hozzáférhetőségük nagyobb tömegben egyszerübben és költséghatékonyabban oldható meg. 
2. táblázat Növények $\mathrm{IC}_{50}$ értékei $(\mu \mathrm{g} / \mathrm{ml})$ és relatív amiláz gátlásuk az akarbózhoz viszonyítva.

\begin{tabular}{lcc}
\hline Növény neve & IC50 $(\boldsymbol{\mu g} / \mathbf{m l})$ & $\begin{array}{c}\text { Relatív gátlás } \\
\text { (IC50/IC50 akarbóz) }\end{array}$ \\
\hline akarbóz (kontroll) & $0,01 \pm 0,002$ & 1 \\
ceyloni fahéj & $0,02 \pm 0,002$ & 3 \\
zöld Tea levél & $0,22 \pm 0,080$ & 36 \\
erdei szamóca levél & $8,84 \pm 2,80$ & 1473 \\
áfonya levél & $25,00 \pm 8,00$ & 4243 \\
babér levél & $25,00 \pm 12,00$ & 4166 \\
szeder levél & $27,27 \pm 9,00$ & 4545 \\
szegfüszeg rügy & $34,00 \pm 5,00$ & 5666 \\
amerikai tőzzegáfonya termés & $41,00 \pm 11,00$ & 6833 \\
\hline
\end{tabular}

\subsubsection{Az extraktumok $\alpha$-glükozidáz gátló hatása}

A komplex szénhidrátok és oligoszacharidok egyszerü cukrokká történő lebontásában az $\alpha$-amilázon kívül az $\alpha$-glükozidázok is részt vesznek, ezért ezen enzimek inhibitorai szintén potenciális eszközöket jelenthetnek az antidiabetikus terápiák számára. Az jól látható (3. táblázat), hogy az akarbóz az $\alpha$-amiláz gátlásán túl az $\alpha$-glükozidáz aktivitását is gátolja, amely megfelel a korábbi irodalmi adatoknak (Kim, Lee et al. 1999). A növényi extraktumok közül az erdei szamóca mutatta a legalacsonyabb $\mathrm{IC}_{50}$ értéket, amely az $\alpha$-glükozidáz gátlás tekintetében alig különbözött az akarbóznál tapasztalt gátló hatástól. Azonban az áfonya és a szeder kivonatok által mutatott gátló hatások is meghaladták a 80 \%-ot.

3. táblázat Növények $\mathrm{IC}_{50}$ értékei $(\mu \mathrm{g} / \mathrm{ml})$ és az $\alpha$-glükozidáz gátlás százalékos értékei.

\begin{tabular}{lcc}
\hline & $\begin{array}{c}\boldsymbol{\alpha} \text {-glükozidáz IC50 } \\
(\boldsymbol{\mu g} / \mathbf{m l})\end{array}$ & $\begin{array}{c}\boldsymbol{\alpha} \text {-glükozidáz gátlás } \\
(\boldsymbol{\%})\end{array}$ \\
\hline Akarbóz & $2,24 \pm 0,01$ & $98,6 \pm 4,8$ \\
Erdei szamóca & $7,67 \pm 0,19$ & $97,21 \pm 7,4$ \\
Szeder & $25,62 \pm 0,85$ & $85,45 \pm 12,3$ \\
Áfonya & $30,46 \pm 0,98$ & $87,65 \pm 9,1$ \\
\hline
\end{tabular}




\subsubsection{A keverékképzés hatása a glikozid-hidroláz enzimekre}

A kiválasztott növények nyers extraktumaiból keveréket készítettünk és annak a korábban is vizsgálat glikozid-hidroláz enzimekre gyakorolt hatását is megvizsgáltuk. Az erdei szamóca, áfonya és szeder extraktumokat is tartalmazó keverék $\alpha$-glükozidáz gátlása során 11,2 $\mu \mathrm{g} / \mathrm{ml} \mathrm{IC}_{50}$ koncentrációval, míg az $\alpha$-amiláz gátlása során $15,3 \mu \mathrm{g} / \mathrm{ml} \mathrm{IC}_{50}$ értékkel volt jellemezhetö. Amely értékek magasabbak a keverék tagjai közül legalacsonyabb értékeket mutató szamócánál, de alacsonyabbak a két gyengébb gátlást okozó növényi extraktumnál. A gátlási \% szintén egy köztes értéket vett fel, hasonlóan az $\mathrm{IC}_{50}$ értékhez, $\alpha$-glükozidáz esetén 93,6\%, míg $\alpha$-amiláz esetén $88,6 \%$ volt.

\subsubsection{A glikozid-hidroláz enzimekre gyakorolt hatás összefoglalása}

A növényi kivonatok dózis függően gátolták az $\alpha$-amiláz és az $\alpha$-glükozidáz aktivitását. Az egyes kivonatokhoz $\mathrm{IC}_{50}$ értéket határoztunk meg. Az erdei szamóca kivonata mindkét glikozid-hidroláz esetében a legalacsonyabb $\mathrm{IC}_{50}$ értéket mutatta, miközben az áfonya és a szeder IC $_{50}$ értéke szignifikánsan magasabb volt. Meg kell jegyezni, hogy mindkét növényi kivonat $\mathrm{IC}_{50}$-értéke hasonló volt mind az $\alpha$-amiláz, mind az $\alpha$-glükozidáz aktivitásban. Az erdei szamóca kivonata a legmagasabb gátló hatást fejtette ki az $\alpha$-amiláz és az $\alpha$-glükozidáz aktivitására. Ezek az eredmények azt mutatták, hogy a vizsgált növényi kivonatok hatékonyan gátolják az $\alpha$-amiláz és $\alpha$-glükozidáz aktivitást in vitro.

A három növény keverékének együttes alkalmazása megerősítette, hogy ezeket a gyógynövényeket keverékben alkalmazva jól használhatóak az étkezés utáni hiperglikémia csökkentésére azáltal, hogy hatékonyan gátolják az $\alpha$-amiláz és $\alpha$-glükozidáz enzimeket.

\subsubsection{Tanninmentesítés hatása a glikozid -hidroláz enzimek gátlására}

Az irodalom szerint a felhasznált növények jelentős mennyiségü tannint tartalmazhatnak, ami nagyon erős gátló hatást eredményez az $\alpha$-amiláz és az $\alpha$-glükozidáz enzimekre (Liberal, Francisco et al. 2014, Pinto Mda, de Carvalho et al. 2010). Azonban igazolni szerettük volna, hogy a hatásért nem csak a tannin lehet a felelős, ezért a tannin gátló hatásának a mértékét a 
keverék minta (erdei szamóca, áfonya és szeder) tannin-mentesítésével igyekeztünk igazolni. Az előkészítést záró végső centrifugálás után jól látható volt a mintákban a kicsapódott tanninfehérje komplex, ami a tannin jelenlétét igazolta.

A tannin-mentesített kivonattal ismételten elvégeztük az aktivitás méréseket és az $\alpha$ amiláz esetében 7,2\%-al az $\alpha$-glükozidáznál pedig 14,9\%-al csökkent az enzimaktivitás a kiindulási aktivitáshoz mérten. A tannin mentesítés után mért $81 \%(\alpha$-amiláz), illetve a $79 \%$ ( $\alpha$-glükozidáz) még így is jelentős gátlásnak mondható, tehát jelentős azon komponensek mennyisége, melyek részt vesznek a glikozid-hidroláz enzimek gátlásában, azaz az extraktumban az $\alpha$-amiláz és $\alpha$-glükozidáz gátlásáért más hatóanyagok is felelősek a tanninon kívül.

\subsection{Az extraktumok antioxidáns hatása}

A növényi hatóanyagoknak azt a képességét, hogy megakadályozzák a szabad gyökök képződését és az azokból eredő káros hatásokat, antioxidáns kötő kapacitásnak nevezzük.

A mérési eredményeket aszkorbinsav ekvivalens értékben adtuk meg. A kiválasztott növényi minták antioxidáns kapacitása a következő eredményeket adta (4. táblázat).

4. táblázat A növények antioxidáns hatásai (átlag $\pm \mathrm{SD})$.

\begin{tabular}{cc}
\hline Növény neve & $\begin{array}{c}\text { Antioxidáns hatás } \\
(\boldsymbol{\mu g} / \mathbf{m g} \mathbf{C} \text {-vitamin })\end{array}$ \\
\hline Áfonya levél & $809,15 \pm 68,27$ \\
Erdei szamóca levél & $490,47 \pm 56,97$ \\
Szeder levél & $366,32 \pm 42,67$ \\
\hline
\end{tabular}




\subsection{A növényi extraktumok tömegspektrometriás analízise}

A három kiválasztott növényi extraktum MALDI-TOF MS spektrumait felvéve, jól látható azok komplexitása (8.-10. ábrák). A komplexitás ellenére, az alkalmazott készülék felbontásának és tömegpontosságának köszönhetően (az ábrákon az $m / z$ értékeket az áttekinthetőség érdekében csak egy tizedes jegyig tüntettük fel) az egyes vegyületekből származó ionok jól elkülöníthetőek.

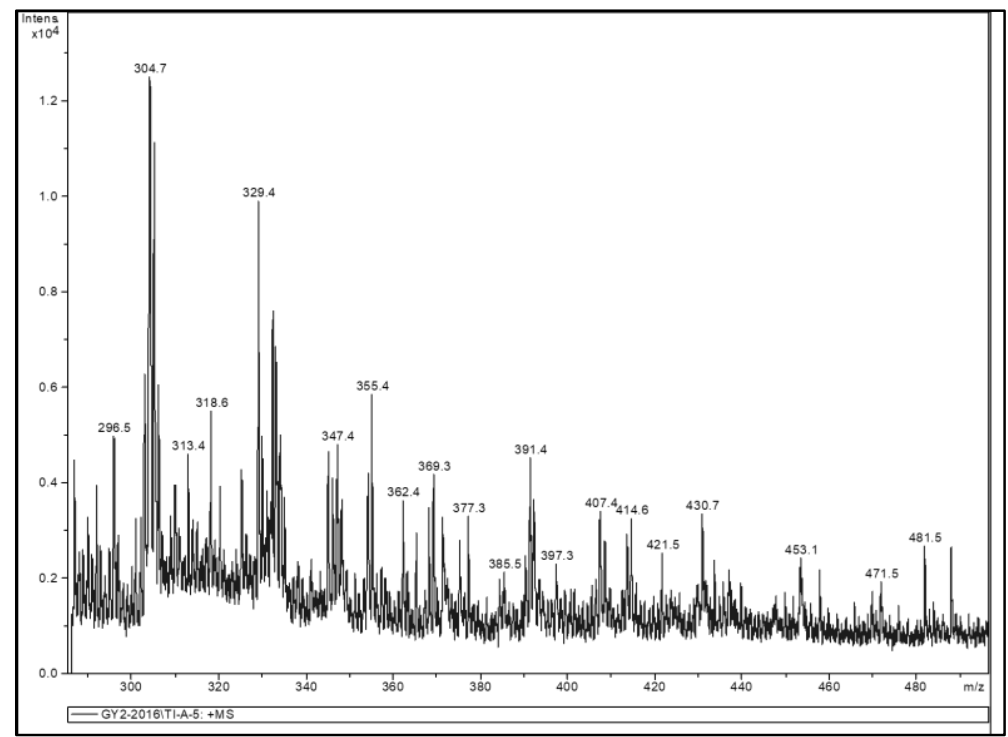

8. ábra Az erdei szamóca kivonat MALDI-TOF MS spektruma 


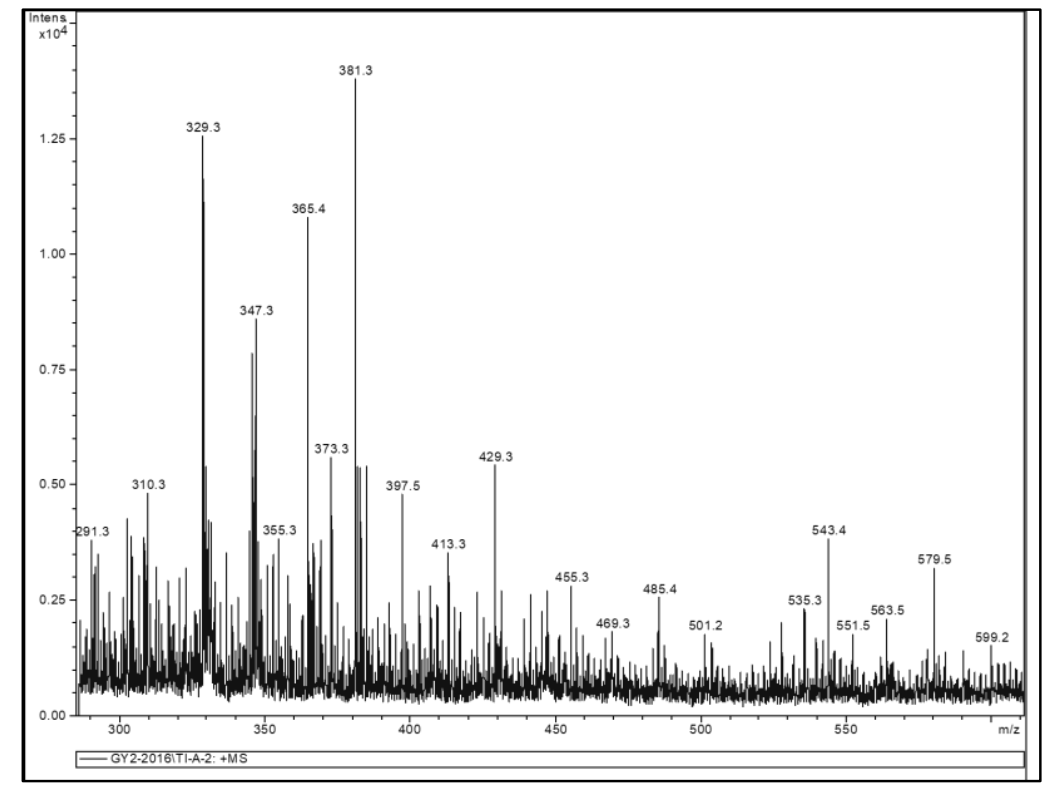

9. ábra A szeder kivonat MALDI-TOF MS spektruma

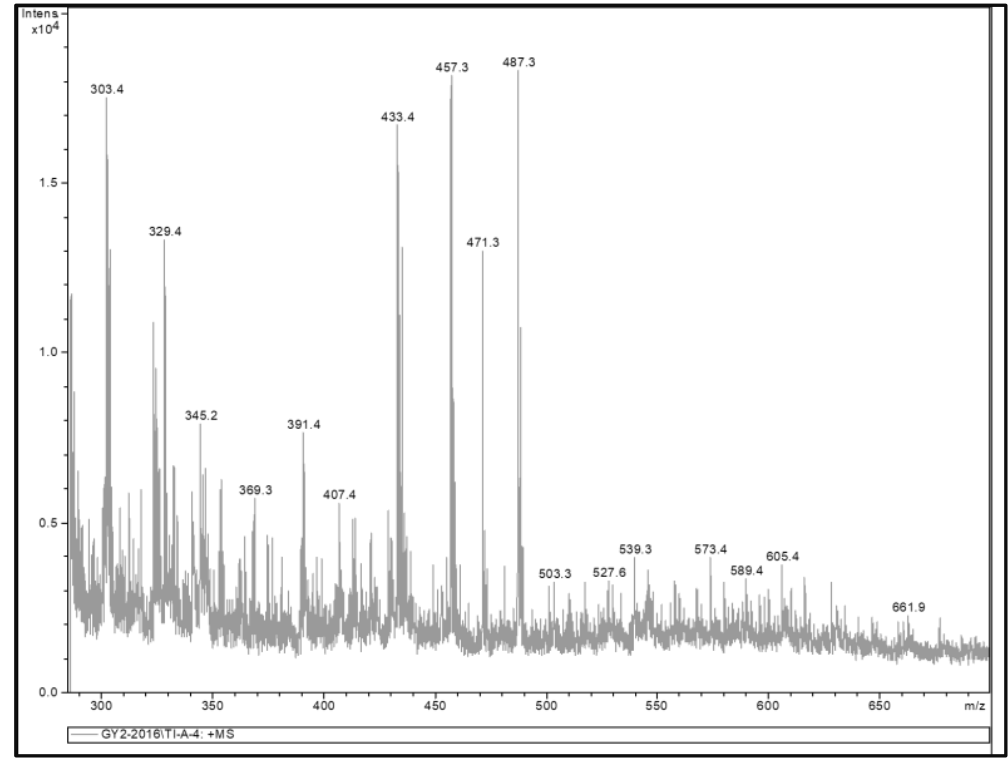

10. ábra Az áfonya kivonat MALDI-TOF MS spektruma 
A növényi extraktumok mérése során a mintában lévő vegyületeket a proton, nátrium és/vagy kálium által kationizált kvázi molekula ionok segítségével azonosítottuk. Azon vegyületek esetében, ahol a molekulaionok tekintetében mind a három, a $[\mathrm{M}+\mathrm{H}]^{+},[\mathrm{M}+\mathrm{K}]^{+}$és $[\mathrm{M}+\mathrm{Na}]^{+} \mathrm{m} / \mathrm{z}$ értékeket is detektáltuk a (5. táblázatban) foglaltuk össze. A detektált vegyületek nagy része a flavonoidok csoportjába tartozott, melyek biológiai aktivitása több aspektusból is ismert, de mint glikozidáz inhibitorok eddig még nem kerültek említésre.

A növényi kivonatok MS-spektrumában a karakterisztikus $m / z$ értékek szerint több azonos molekulatömegủ anyagot lehet feltételezni amelyek, nagy valószínűséggel a kondenzált tanninokként ismert oligomer és polimer egységeknek felelnek meg. Ilyen például a katechin, epikatechin, gallokatechin, epigallokatechin, epigallokatechin gallát stb. A katechin és az epikatechin két flavan-3-ol, amelyeket leggyakrabban azonosítanak a vizsgált növényekben. A flavonolok főleg konjugált formájukban lehetnek jelen, amelyek glikozidok keverékét alkotják. A flavonoidok a növényekben föként glikozidokként fordulnak elö, azaz különböző cukrokhoz kapcsolódnak.

Az irodalom szerint szeder levélben több flavonoidot és ezek glikozidjait is kimutatták, melyek a következők voltak: hiperozid, kvercetin-3'-glükozid, kvercetin-7-O-glükozid, miricetin $\left(\mathrm{C}_{24} \mathrm{H}_{22} \mathrm{O}_{15}\right)$; apigenin-7-O-glükozid, kamferol-5-ramnozid, luteonil-7-ramnozid $\left(\mathrm{C}_{21} \mathrm{H}_{20} \mathrm{O}_{10}\right)$; rutin, kvercetin-3-rutinozid ( $\left.\mathrm{C}_{27} \mathrm{H}_{30} \mathrm{O}_{16}\right)$; kampferol-3-glükozid-7-galaktozid, luteolin-7-diglikozid $\left(\mathrm{C}_{27} \mathrm{H}_{30} \mathrm{O}_{16}\right)$; kampferol-3-O-rutinozid, luteolin-5-O-rutinozid, apigenin-7,4'-diglükozid $\left(\mathrm{C}_{27} \mathrm{H}_{30} \mathrm{O}_{15}\right)$; katechin, epikatechin $\left(\mathrm{C}_{15} \mathrm{H}_{14} \mathrm{O}_{6}\right)$; gallokatekin, epigallokatekin $\left(\mathrm{C}_{15} \mathrm{H}_{14} \mathrm{O}_{7}\right)$ (Zia-Ul-Haq, Riaz et al. 2014, Gudej, Tomczyk 2004). A tömegspektrometriás adatokat alapul véve, és a publikált adatok adatai alapján az $\left(\mathrm{C}_{21} \mathrm{H}_{18} \mathrm{O}_{11}\right)$ összegképletű vegyület megfelelhet az apigenin-7-O-glükuronidnek és apigenin7-galakturonidnek is. Egy tanulmány szerint e hatóanyagok kísérletesen tapasztalt hipoglikémiás hatása a hasnyálmirigy $\alpha$-amiláz gátlása révén következik be. $\mathrm{Az}$ in silico vizsgálatok megerősítették, hogy az apigenin glikozidjai az $\alpha$-amilázt nem kompetitív inhibitorként gátolják (Ratna Wulan, Priyo Utomo et al. 2015). Az apigenin és származékai csökkentették az éhgyomri vércukorszintet és a plazma inzulin szintjét és javították az inzulinrezisztenciát és gyulladáscsökkentő hatást mutattak bizonyos kísérletek szerint (Jung, Cho et al. 2016). Továbbá az apigenin szignifikánsan csökkentette az éhgyomri vércukorszintet a magas zsír és cukor tartalmú táppal kezelt egerekben. A plazma inzulin és a HOMA-IR szinteket szintén szignifikánsan csökkentette ez a vegyület (Shi, Zhuang et al. 2015). Az apigenin csökkenti az éhgyomri vércukorszintet a máj glükonogén enzimaktivitásának 
gátlásával, és a májban lévő glükóz szabályozó enzimekben bekövetkező változások miatt. Ezenkívül a proinflammatorikus mediátorok plazmaszintjei, például az IFN- $\gamma$, a TNF- $\alpha$ és az IL-6, szignifikánsan csökkentek az apigenin hatására (Jung, Cho et al. 2016).

A szeder és szamóca leveleiben lévő flavonoidok és fenolos komponenseknek köszönhetően magas antioxidáns kapacitást mértünk, amit más szerzők munkája is alátámasztott (Wang, Lin 2000a). A kvercetin és glikozidjainak jótékony hatását, és jól jellemzett antioxidáns tulajdonságát több in vitro és in vivo vizsgálat is megerösítette (Rao, Geethangili et al. 2007, Boots, Haenen et al. 2008). Számos tanulmány foglalkozott a kvercetinnel mint potenciális antidiabetikus gyógyszerrel (Mahmoud, Hassan et al. 2013). A kvercetin csökkenti a lipidperoxidációt és megemeli az antioxidáns enzimeket, mint például a SOD, GPX, és a CAT aktivitását. Csökkenti a glükóz felszívódását azáltal, hogy gátolja GLUT2 receptor müködését (Coskun, Kanter et al. 2005). Egy másik fontos glükóz receptor a GLUT4 transzlokációját és expresszióját stimulálja a vázizomban az adenozin-monofoszfát-aktivált protein-kinázzal (AMPK) kapcsolatos mechanizmusok útján. A májban ez a kináz csökkenti a glükóz termelését elsősorban úgy, hogy szabályozza a kulcsfontosságú szénhidrát anyagcsere enzimek müködését (Eid, Nachar et al. 2015). A kvercetin javítja a máj és a hasnyálmirigy funkciókat a sejt proliferáció gátlása révén, amelyek lehetővé teszi az STZ indukció következtében bekövetkezett génexpressziós változásokat (Kobori, Masumoto et al. 2009, Kobori, Masumoto et al. 2011). A vizsgálatok az is kimutatták, hogy a magas zsírtartalmú étrenden tartott és streptozotocinnal indukált diabéteszes egerekben és patkányokban a kvercetin jelentősen csökkentette a májban a zsír felhalmozódását. A kvercetinnel táplált egerekben további pozitív hatásokat is észleltek, alkalmazása moderálta a hiperglikémiás, hiperinzulinémiás, diszlipidémiás hatásokat és csökkentette a plazma TNF- $\alpha$-szintjét. A kvercetin védő hatást fejt ki a hasnyálmirigy $\beta$-sejteiben a STZ-al előidézett oxidatív stresszel szemben. A kezelés megvédte a hasnyálmirigy $\beta$-sejtjeinek szerkezeti integritását az STZindukált oxidatív stresszel szembeni szövetkárosodástól, és fokozta az endogén antioxidánsok mennyiségét (Mahmoud, Hassan et al. 2013, Adewole, Caxton-Martins et al. 2006). A kvercetin erősen gátolja az $\alpha$-glükozidáz aktivitását in vitro és in vivo körülmények között ezért potenciális antidiabetikus szerként tarják számon (Kim, Kang et al. 2011).

A fekete áfonyában is több azonos típusú kvercetin-3-glükozidot, és kvercetin-3rutinozidot azonosítottak (Antolak, Czyzowska et al. 2016). Méréseink során az $\mathrm{m} / \mathrm{z}$ értékük szerint több kvercetin glikozidnak megfelelő anyagot tudtunk azonosítani. A fenol vegyületek mennyisége szignifikánsan korrelált a vizsgált minták antioxidáns aktivitásával 
ezért a szederlevél az antioxidáns vegyületek jó forrásának tekinthető. A szederlevél és az áfonyalevél, mint élelmiszer-adalékanyag, vagy mint tea felhasználására vannak példák az irodalomban (Ieri, Martini et al. 2013). A kvercetin-3-O-glükuronid a legelterjedtebb flavonol és koncentrációja a teljes flavonolok 70-93\% -át teszi ki. Egyéb flavonolok a feketeáfonya levelekben a kvercetin-3-O- $\beta$-galaktozid (4,06\%), kvercetin-3-O-(4"-HMG)- $\alpha$-ramnozid (3,48\%), kvercetin-3-O-arabinozid (2,92\%), a kvercetin-3-O-glükozid (0,99\%), a kvercitrin $(0,73 \%)$ és a kvercetin (0,03\%) (Hokkanen, Mattila et al. 2009). A kvercetin és glikozididjai az egyik legszélesebb körben használt flavonoid vegyületek a humán táplálkozási rendszerben (Hollman, de Vries et al. 1995). Az irodalmi adatok alapján az áfonya levél kivonatában azonosított $\left(\mathrm{C}_{21} \mathrm{H}_{18} \mathrm{O}_{12}\right)$ képletü vegyület megfelelhet a luteolin és a kaemferol különböző glikozidjainak. A luteolin növelte az inzulinérzékenységet a peroxiszóma proliferátor-aktivált receptor $(\operatorname{PPAR} \gamma)$ transzkripciós aktiválásán keresztül az adipocitákban. Ezenkívül a luteolin kezelés csökkentette a TNF $\alpha$, az interleukin-6 mRNS szintjét, miközben növeli az adiponektin és a leptin gén expresszióját az adipocitákban (Ding, Jin et al. 2010). A kaempferol glikozidok a flavonol csoportba tartoznak és gyakran megtalálhatók bogyós gyümölcsökben és annak leveleiben (Hakkinen, Karenlampi et al. 1999). Kimutatták, hogy a kaempferol adagolása diabéteszes patkányoknál visszaállította közel normális szintre a plazma glükóz szintjét és javította az inzulin értékeket a lipid peroxidációs termékeket és az enzimatikus antioxidánsok mennyiségét is (Al-Numair, Chandramohan et al. 2015). Az orálisan adagolt kaempferol szignifikánsan csökkentette az éhgyomri vércukorszintet és javította az inzulin rezisztenciát. A kaempferol csökkentette a PPAR- $\gamma$ expresszióját is, így a vegyület az elhízás elleni és antidiabetikus hatását a PPAR- $\gamma$ gének szabályozás révén közvetíti az AMPK aktivációján keresztül (Zang, Zhang et al. 2015). Az in vitro eredmények igazolták, hogy a kaempferol kezelés $(10 \mu \mathrm{M})$ elősegítette az életképességet, gátolta a sejt-apoptózist és csökkentette kaszpáz-3-aktivitást a $\beta$-sejtekben, amelyek krónikus hiperglikémiás állapotnak voltak kitéve.

A kiértékelő szoftver által javasolt $\left(\mathrm{C}_{17} \mathrm{H}_{14} \mathrm{O}_{8}\right)$ tapasztalati képlet megfeleltethető a taxifolinnak, ami egy bioflavonoid és hasonló szerkezetü, mint a kvercetin. A STZ-indukált diabéteszes egerekben és in vitro $\mathrm{H} 9 \mathrm{c} 2$ kardiális mioblaszt tenyészetekben a taxifolin hatására javult a diasztolés diszfunkció és a szívizom szerkezeti abnormalitás (46). Gátolta a szívizomsejtben az apoptózist és fokozta az endogén antioxidáns enzimek tevékenységét. A cukorbetegeknél fellépő szív és keringési elégtelenségeket és az ebből kialakuló szívizom strukturális és funkcionális rendellenességeket egyre inkább felelőssé teszik a diabetikus kardiomiopátia kialakulásában. Úgy gondolják, hogy a kifejlődésében fontos szerepet játszik 
az oxidatív stressz, melynek leküzdésében szerepe lehet a taxifolin védőhatásának (Yan, Zhang et al. 2013). Az in vitro vizsgálat kimutatta, hogy a taxifolin gátolta a magas glükóz koncentrációval aktivált H9c2 sejtek apoptózisát is (Faria, Persaud 2017).

A $\left(\mathrm{C}_{27} \mathrm{H}_{30} \mathrm{O}_{16}\right)$ tapasztalati képlet megfelelhet a rutinnak, melyet és több azonos típusú flavonoidot azonosítottak az erdei szamócában is (Bagdonaite, Jakstas et al. 2013). Egy friss tanulmány megerősíti a rutin antidiabetikus hatását, amelyet a fehér eperfa levélben azonosítottak (Hunyadi, Martins et al. 2012a). A rutinnal kezelt diabetikus egerekben csökkent plazma glükóz értékeket, és megnövekedett inzulin szintet mutattak ki. Továbbá megfigyelték a glikogén tartalom és a szénhidrátbontó enzimek szintjének normalizálását (Stanley Mainzen Prince, Kamalakkannan 2006). A rutin alkalmazása az STZ indukált cukorbeteg patkányoknál csökkentette a plazma glükóz és HbA1c szintet valamint fokozta a máj antioxidáns enzimjeinek termelését (Niture, Ansari et al. 2014). A rutin aktiválta a glükoneogenetikus és anyagcsere (Hao, Shao et al. 2012).

5. táblázat A növényi kivonatok MS-spektrumában azonosított vegyületek és a kapcsolódó

\begin{tabular}{|c|c|c|c|c|c|c|}
\hline \multirow[t]{2}{*}{ Képlet } & \multirow[t]{2}{*}{$\begin{array}{c}\text { Feltételezett } \\
\text { vegyület }\end{array}$} & \multicolumn{3}{|c|}{ Molekulaionok (m/z) } & \multirow[t]{2}{*}{$\begin{array}{c}\text { Növényi } \\
\text { extraktum }\end{array}$} & \multirow[t]{2}{*}{ Referencia } \\
\hline & & {$[\mathrm{M}+\mathrm{H}]^{+}$} & {$[\mathrm{M}+\mathrm{Na}]^{+}$} & {$[\mathrm{M}+\mathrm{K}]^{+}$} & & \\
\hline $\mathrm{C}_{15} \mathrm{H}_{14} \mathrm{O}_{6}$ & $\begin{array}{l}\text { katechin, } \\
\text { epikatechin }\end{array}$ & 291,0863 & 313,0683 & 329,0420 & $\begin{array}{l}\text { erdei } \\
\text { szamóca } \\
\text { szeder }\end{array}$ & $\begin{array}{l}\text { (Rana Jenish, Patel et al., } \\
\text { Gasperotti, Masuero et al. } \\
\text { 2013, Najda, Dyduch- } \\
\text { Sieminska et al. 2014, Gudej, } \\
\text { Tomczyk 2004) }\end{array}$ \\
\hline $\mathbf{C}_{15} \mathbf{H}_{14} \mathbf{O}_{7}$ & $\begin{array}{l}\text { gallokatechin } \\
\text { epigallokatechin }\end{array}$ & 307,0812 & 329,0632 & 345,0370 & $\begin{array}{c}\text { erdei } \\
\text { szamócasze } \\
\text { der }\end{array}$ & $\begin{array}{l}\text { (Giampieri, Alvarez-Suarez } \\
\text { et al. 2014, Liberal, } \\
\text { Francisco et al. 2014, Gudej, } \\
\text { Tomczyk ) }\end{array}$ \\
\hline $\mathrm{C}_{21} \mathrm{H}_{18} \mathrm{O}_{11}$ & $\begin{array}{l}\text { apigenin-7- } \\
\text { glükuronid }\end{array}$ & 447,0922 & 469,0741 & 485,0480 & áfonya & $\begin{array}{l}\text { (Shi, Zhuang et al. 2015, } \\
\text { Ross, Kasum 2002) }\end{array}$ \\
\hline $\mathbf{C}_{15} \mathbf{H}_{10} \mathbf{O}_{7}$ & kvercetin & 303,0499 & 325,0319 & 341,0058 & $\begin{array}{l}\text { áfonya } \\
\text { szamóca }\end{array}$ & $\begin{array}{l}\text { (Giampieri, Alvarez-Suarez } \\
\text { et al. 2014, Vessal, Hemmati } \\
\text { et al. 2003, Liberal, } \\
\text { Francisco et al. 2014) }\end{array}$ \\
\hline $\mathrm{C}_{24} \mathrm{H}_{22} \mathrm{O}_{15}$ & $\begin{array}{l}\text { kvercetin-3-O- } \beta \text { - } \\
\text { D-(6 "- } O \text {-alonil)- } \\
\text { glükozid, } \\
\text { miricetin-3-(4- } \\
\text { malonil-ramnozid) }\end{array}$ & 551,1031 & 573,0851 & 589,0590 & $\begin{array}{l}\text { erdei } \\
\text { szamócaáfo } \\
\text { nya }\end{array}$ & $\begin{array}{l}\text { (Hakkinen, Karenlampi et al. } \\
\text { 1999, Tadera, Minami et al. } \\
\text { 2006, Vagiri, Conner et al. } \\
\text { 2015) }\end{array}$ \\
\hline $\mathrm{C}_{21} \mathrm{H}_{20} \mathrm{O}_{12}$ & $\begin{array}{l}\text { hiperozid, } \\
\text { miricitrin }\end{array}$ & 465,1027 & 487,0847 & 503,0590 & $\begin{array}{l}\text { szeder, } \\
\text { áfonya }\end{array}$ & $\begin{array}{l}\text { (Bagdonaite, Jakstas et al. } \\
\text { 2013, Trumbeckaite, } \\
\text { Bernatoniene et al. 2006) }\end{array}$ \\
\hline $\mathrm{C}_{17} \mathrm{H}_{14} \mathrm{O}_{8}$ & $\begin{array}{l}\text { taxifolin-3-O- } \\
\text { acetát }\end{array}$ & 347,0761 & 369,0581 & 385,0320 & áfonya & (Sun, Chen et al. 2014) \\
\hline
\end{tabular}




\begin{tabular}{|c|c|c|c|c|c|c|}
\hline $\mathrm{C}_{21} \mathbf{H}_{20} \mathrm{O}_{10}$ & $\begin{array}{l}\text { apigenin-7-O- } \\
\text { glükozid, } \\
\text { kamferol-5- } \\
\text { ramnozid, } \\
\text { luteonil-7- } \\
\text { ramnozid }\end{array}$ & 433,1129 & 455,0949 & 471,0690 & szeder & $\begin{array}{l}\text { (Ross, Kasum 2002, } \\
\text { Oszmianski, Nowicka et al. } \\
\text { 2015) }\end{array}$ \\
\hline $\mathrm{C}_{21} \mathrm{H}_{18} \mathrm{O}_{12}$ & $\begin{array}{l}\text { luteolin-7- } \\
\text { glükuronid, } \\
\text { kampferol-3- } \\
\text { glükuronid, } \\
\text { kampferol-7- } \\
\text { glükuronid }\end{array}$ & 463,0871 & 485,0690 & 501,0430 & $\begin{array}{l}\text { áfonya } \\
\text { szeder }\end{array}$ & $\begin{array}{l}\text { (Al-Numair, Chandramohan } \\
\text { et al. 2015, Giampieri, } \\
\text { Alvarez-Suarez et al. 2014, } \\
\text { Liberal, Francisco et al. } \\
\text { 2014, Zhang, Liu 2011) }\end{array}$ \\
\hline $\mathrm{C}_{27} \mathrm{H}_{30} \mathrm{O}_{16}$ & $\begin{array}{l}\text { rutin, (kvercetin- } \\
\text { 3-rutinozid), } \\
\text { kampferol-3- } \\
\text { glükozid-7- } \\
\text { galaktozid, } \\
\text { luteolin-7- } \\
\text { diglikozid }\end{array}$ & 611,1607 & 633,1426 & 649,1165 & $\begin{array}{l}\text { áfonya } \\
\text { szeder }\end{array}$ & $\begin{array}{l}\text { (Niture, Ansari et al. 2014, } \\
\text { Hunyadi, Martins et al. } \\
\text { 2012b, Bagdonaite, Jakstas et } \\
\text { al. 2013, Stanley Mainzen } \\
\text { Prince, Kamalakkannan } \\
\text { 2006) }\end{array}$ \\
\hline $\mathrm{C}_{27} \mathbf{H}_{30} \mathrm{O}_{15}$ & $\begin{array}{l}\text { kampferol-3-O- } \\
\text { rutinozid, } \\
\text { luteolin-5-O- } \\
\text { rutinozid, } \\
\text { apigenin-7,4'- } \\
\text { diglükozid }\end{array}$ & 595,1653 & 617,1472 & 633,1212 & $\begin{array}{c}\text { szeder } \\
\text { szamóca }\end{array}$ & $\begin{array}{l}\text { (Jouad, Maghrani et al. } \\
\text { 2002a, Wang, Lin 2000b, } \\
\text { Gudej, Tomczyk, Jouad, } \\
\text { Maghrani et al. 2002b) }\end{array}$ \\
\hline
\end{tabular}

\subsection{A növényi kivonatok citotoxicitásának vizsgálata}

A növényi kivonatok citotoxicitásának mérését még az állatkísérletek előtt elvégeztük H9c2 patkány embrionális szívizomsejteken annak megállapítása céljából, hogy a vizsgálatra szánt növényi hatóanyagok milyen hatást fejtenek ki in vitro (11. ábra).
A
B

$\mathrm{C}$

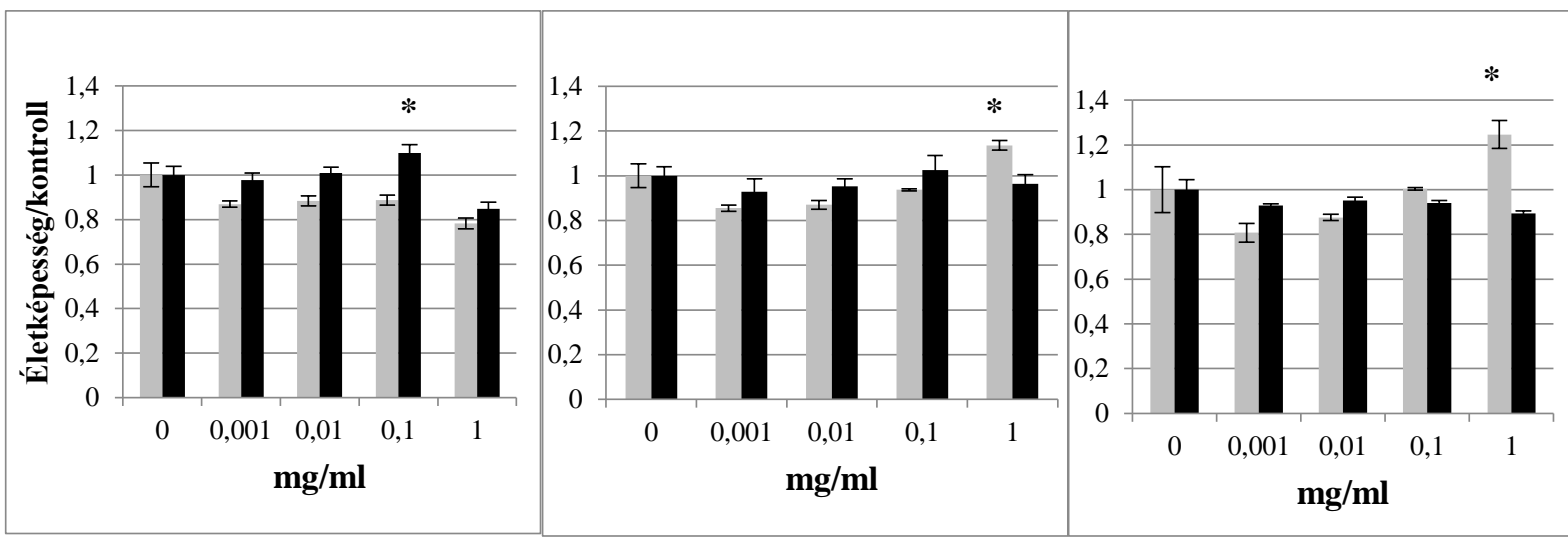

11. ábra A növényi kivonatok hatása a H9c2 sejtek életképességére. A. áfonya levél, B. szeder levél, C. erdei szamóca levél kivonatok. A szürke oszlopok jelölik a 24 h, a fekete oszlopok a 48 h inkubációs idő utáni leolvasást. A kezelt sejtek értékei: középérték $\pm \mathrm{SD}, \mathrm{Az}$ adatokat egymintás ANOVA-val, majd a Tukey post hoc tesztel értékeltük. Az eltéréseket *p $<0,05$ esetén tekintettük szignifikánsnak a kontrollhoz képest. 
A citotoxicitási kísérletek során az áfonya levél kivonat a 24 órás inkubáció alatt minden egyes tesztelt koncentráció esetében egy mérsékeltebb életképesség csökkenést okozott. Az áfonya és az erdei szamóca extraktumok azonban a 24 órás kezelés után kisebb koncentrációban $(0,001$ $0,01 \mathrm{mg} / \mathrm{ml}$ ) okoztak némi életképesség csökkenést, azonban ez a kezelési koncentráció növelésével átfordult egy életképességet növelő hatásba $(1 \mathrm{mg} / \mathrm{ml})$. A 48 órás kezelést követően az áfonya esetében nem volt mérhető hatás az alacsonyabb koncentrációk esetében, a 0,1 mg/ml-es koncentrációnál azonban életképesség növekedés, míg az $1 \mathrm{mg} / \mathrm{ml}$-es koncentráció esetében életképesség csökkenés volt tapasztalható. Érdekes, hogy a szeder és erdei szamóca kivonatok sejteken kifejtett életképesség növelő hatása a 48 órás kezelést követően már nem mutatkozott meg, sőt szinte minden koncentráció esetén az életképesség csekély mértékü csökkenése volt megfigyelhető.

Az elvégzett vizsgálatok alapján mindenképpen kijelenthető, hogy az alkalmazott növényi kivonatok nem tekinthetők toxikusnak az alkalmazott in vitro rendszerben.

\subsection{A növényi kivonatok citoprotekciójának vizsgálata}

A citoprotekciós kisérletekben alkalmazott rendszer legfontosabb tulajdonsága, hogy non-invazív módon vizsgálja az élő sejteket, vagyis semmilyen anyagot, vegyszert, kémiai indikátort nem igényel a sejtek állapotának vizsgálata közben. A citotoxicitás vizsgálata alapján várható volt, hogy a kivonatok citoprotekciós hatással rendelkeznek. Azonban az alkalmazott kisérletben a stresszként használt hidrogén-peroxidos kezelés hatását nem tudta megvédeni egyik kivonat sem (12. ábra), míg a kontrollként alkalmazott vegyület igen (világos kék adatok). 

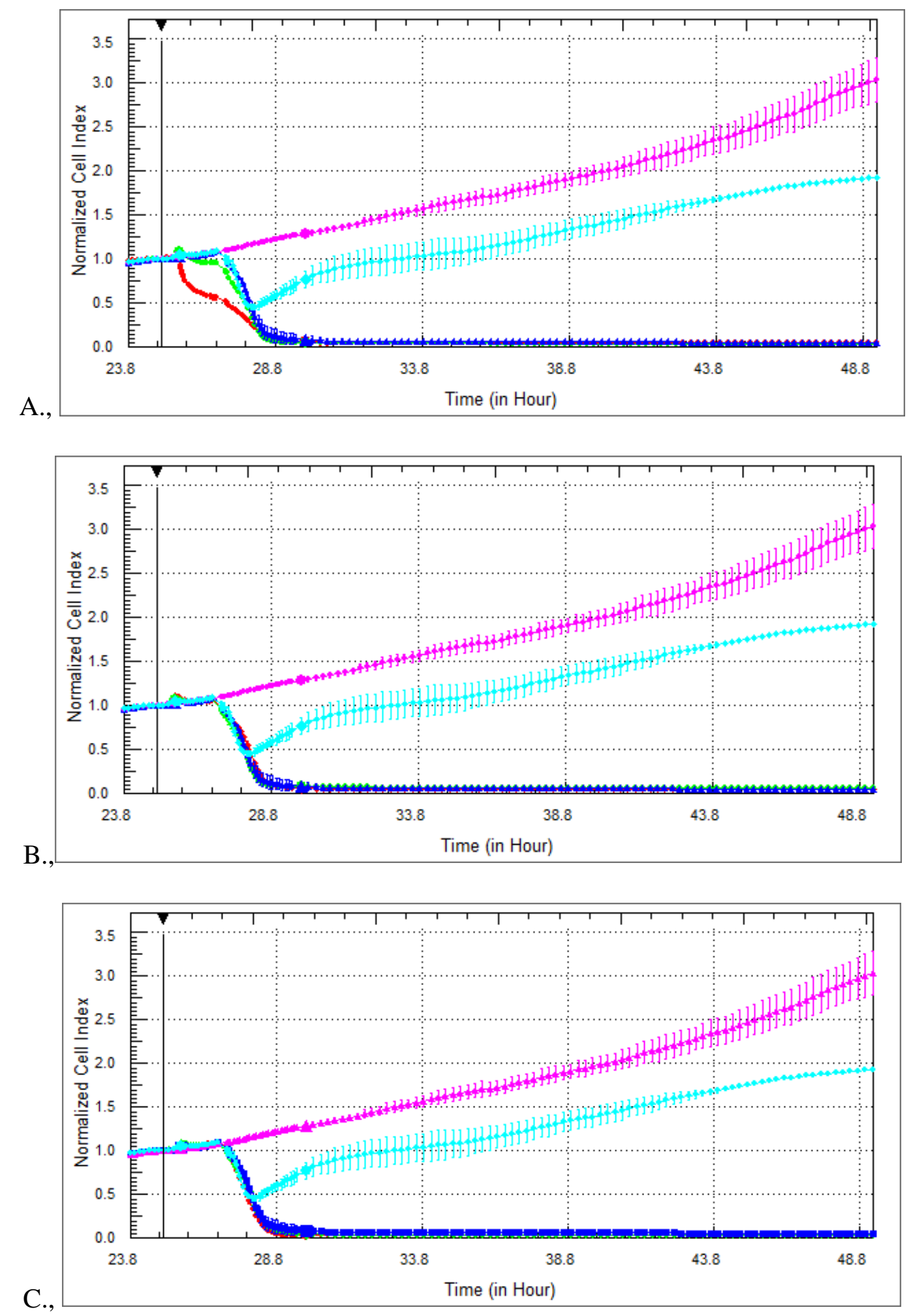

12. ábra $A$ növényi kivonatok citoprotekciós hatásának vizsgálata. A. áfonya, B. szeder, $C$. erdei szamóca kivonatok. A kezeletlen kontroll (lila), a hidrogén-peroxiddal kezelt citoprotektív hatóanyag (világos kék, pozitív kontroll), a hidrogén-peroxiddal kezelt sejtek (sötétkék, negatív kontrol) tüntettük fel. A növényi extraktumok adatait piros $(1 \mathrm{mg} / \mathrm{ml})$ és zöld $(0,1 \mathrm{mg} / \mathrm{ml})$ színnel jelöltük. 


\subsection{A növényi kivonatok in vivo vizsgálata}

A növény kivonatok in vivo hatásának vizsgálatához először a normál kontroll egereket (CD1) egy éjszakán át éheztettük, majd kukoricakeményítővel és növény kivonattal vagy akarbózzal (pozitív kontrollként) kombináltan kezeltük. A kiindulási vércukorszintjük az éjszakai éheztetés után 4,5 $\pm 0,44 \mathrm{mmol} / 1$ volt. A kukoricakeményítő orális beadását követően a vér glükóz szintje jelentősen megemelkedett, a kezelést követő 60. percben tetőzött, és 180 perccel a keményítő beadás után fokozatosan csökkent a kiindulási értékre (13. ábra).

Ezt követően megvizsgáltuk, hogy a növényi kivonat képes-e csökkenteni a keményítő által kiváltott vércukorszint emelkedését a STZ által indukált diabéteszes egerekben. Az egyszeri 200 mg/tstkg adagolású STZ kezelés utáni eredményeket az 5. és 10. napon vizsgáltuk. Azok a kontroll egerek, amelyek csak csapvizet kaptak, nem mutattak szignifikáns vércukorszint emelkedést a kísérlet során. Az akarbóz (10 mg/tstkg) teljesen megakadályozta a keményítő által kiváltott vércukorszint növekedést. A növényi kivonat (1200 mg/tstkg) szintén szignifikánsan gátolta a vércukorszint növekedését a kukoricakeményítő beadását követően (13. ábra). Ezután megvizsgáltuk, hogy a növényi kivonat képes-e csökkenteni a keményítő által kiváltott vércukorszint emelkedését és a STZ által indukált diabéteszes egerekben. Az egyszeri adagolású STZ kezelés eredményeként az 5. és 10. nappal (14.-15. ábra). A kezelés utáni 5. és 10. nap (az 5. nap 29,36 $\pm 4,85 \mathrm{mmol} / \mathrm{l}$ és a 10.nap 31,88 mmol/l ) elteltével emelkedett a vércukorszint. A basalis vércukorszintek az éjszakai éhezés után hasonlóak voltak a kontroll és a STZ-kezelt egereknél az injekció után 5 nappal, azonban szignifikánsan emelkedett szinteket mértünk 10 nappal az STZ injekció után, jelezve az inzulintermelő sejtek progresszív elvesztését és a glükóz-homeosztázis gyengeségét. Az oldható kukoricakeményítő kezelés szignifikáns és tartós "posztprandiális" hiperglikémiát eredményezett minden STZkezelt egérben.. A keményítővel kezelt, STZ-diabetikus egerek csúcskoncentrációja magasabb volt, mint a nem diabéteszes állatoknál (16,4 $\pm 1,8 \mathrm{mmol} / 1$, STZ 5 nap, 19,5 $\pm 3,0 \mathrm{mmol} / \mathrm{l} \mathrm{STZ}$ 10 nap, szemben a 11,4 $\pm 1,5 \mathrm{mmol} / \mathrm{l}$, nem diabetikus). Amikor a kukoricakeményítőt akarbózzal vagy a növényi kivonattal együtt adtuk, a vér glükózszintje nem emelkedett szignifikánsan a mintavétel időpontjában, ami a keményítőt lebontó enzimaktivitás gátlását jelezte.

A jelenlegi adatok alapján a növényi kivonatok (1200 mg/tstkg) ugyanolyan hatásosak voltak, mint az akarbóz (10 mg/tstkg) a keményítő által kiváltott vércukorszint emelkedésének megelőzésében, prediabetikus és diabeteses egerekben. A növényi kivonatnak (1200 mg/kg) az 
STZ-indukált egereknek emelt adagban (3-szor napi 2x) történő adagolása nem csökkentette a bazális vércukorszinteket.

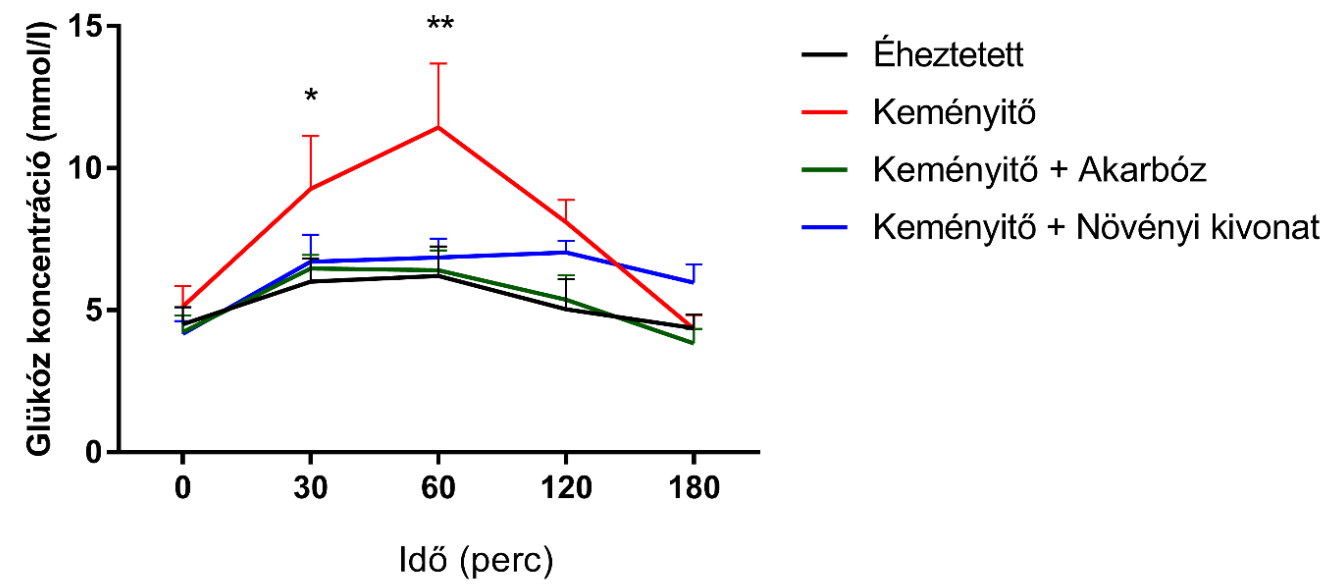

13. ábra $A$ kontroll egerek (CD1) vércukorszintjének változása. A középérték $\pm S E M$ értékeket többszörös t-teszttel elemeztük. */**P <0,05 keményítő+növényi kivonat vs. keményítő.

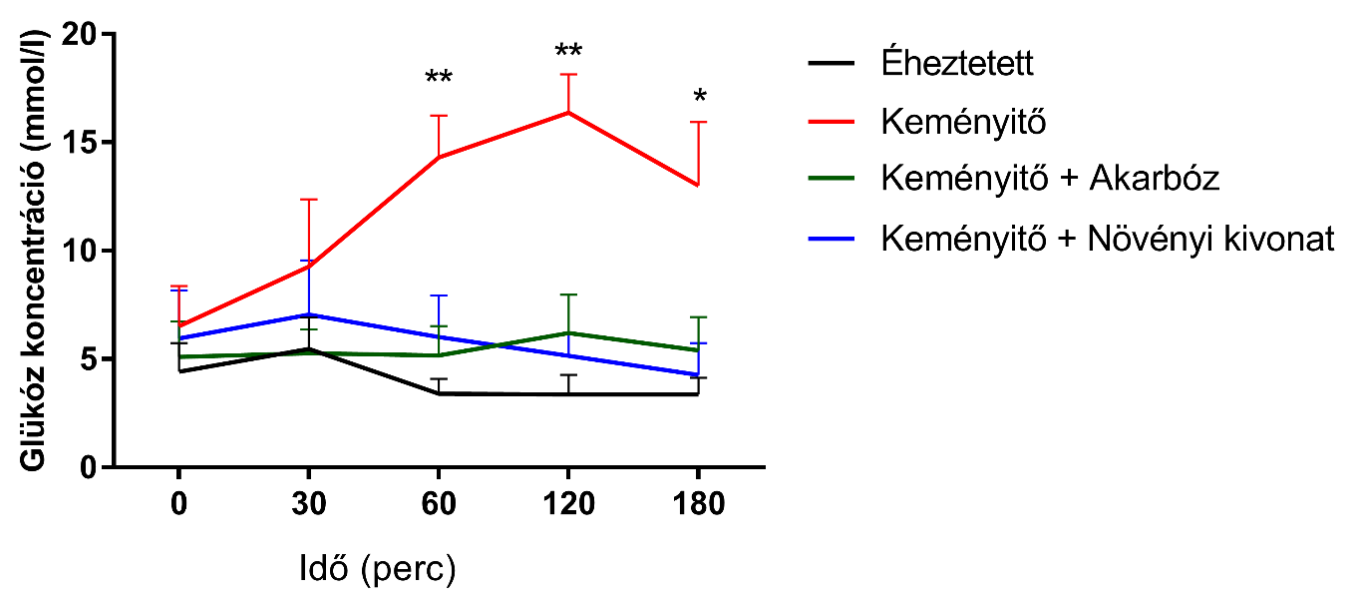

14. ábra CD1 STZ indukált egér kezelés utáni 5. nap. A középérték $\pm S E M$ értékeket többszörös t-teszttel elemeztük. */**P <0,05 keményítő+növényi kivonat vs. keményítő. 


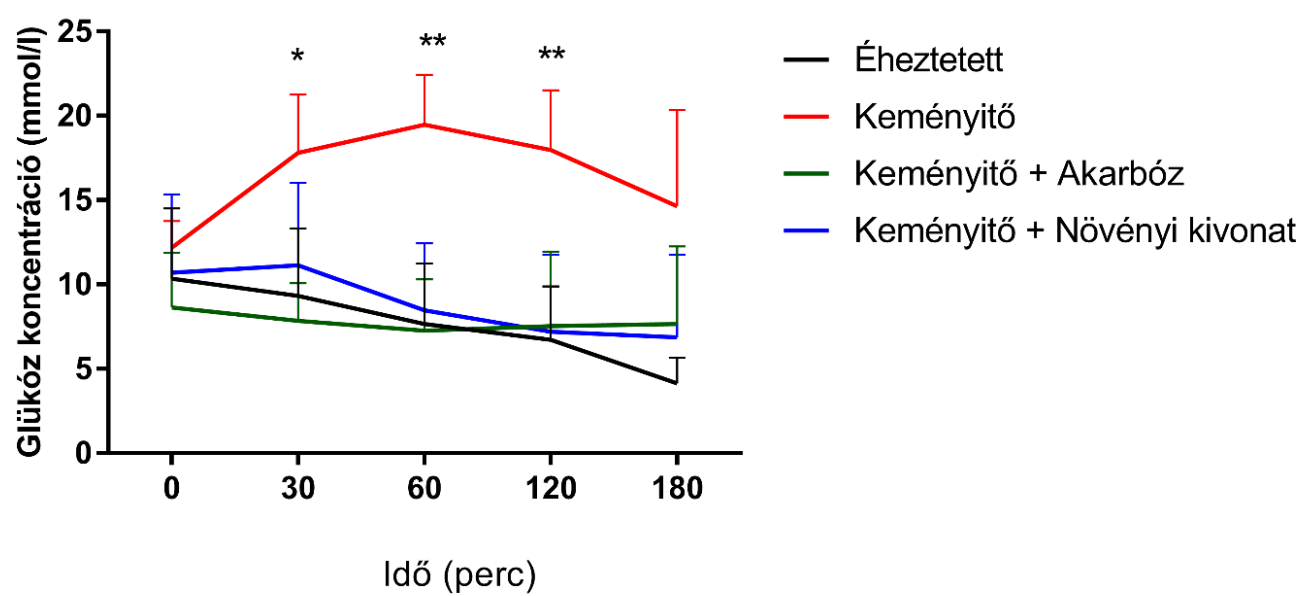

15. ábra CD1 STZ indukált egér kezelés utáni 10. nap. A középérték \pm SEM értékeket többszörös t-teszttel elemeztük. ***P $<0,05$ keményítő+növényi kivonat vs. keményítő.

Ezután megvizsgáltuk a növényi kivonatok hatását a prediabetikus állatokon ugyanazt a kísérleti elrendezést alkalmazva mint korábban. Az egyetlen különbség az volt, hogy a nem diabetikus egerekben mért glükóz szint a kísérlet elején és végén a fiziológiai tartományban volt. A C57BL6 egerek nyugati stílusú étrenddel (16. ábra) magas zsír- és szacharóz tartalmú (HFHS) diétán történő étkezést 5 hónapon keresztül, ami jelentős súlygyarapodást eredményezett ( $27 \pm 1,1 \mathrm{~g}$ vs. 2,5 $\pm 0,8 \mathrm{~g})$ és csökkent glükóz toleranciát. Várakozásaink szerint a pre-diabetikus egerek vércukor-koncentrációja 5 hónappal a kezelés után magasabb volt, mint a kísérlet elején $\left(10,84 \pm 0,17\right.$ és $\left.7,61 \pm 0,15 \mathrm{mmol} / 1,{ }^{*} p<0,01\right)$. A vércukorszint a keményítő hatására emelkedett 14,0 mmol/1-ra (30 perc), majd fokozatosan csökkent a kezdő időponthoz közeli értékre (17. ábra). Azonban, ha a keményítőt akarbózzal (10 mg/tstkg) vagy növényi kivonattal (1200mg/tstkg) együtt adtuk, a vércukorszint jelentősen alacsonyabb volt, mint a keményítő adagolás után. Meglepő módon az akarbózzal vagy növényi kivonattal kezelt prediabetikus egerek glükóz koncentrációja nagyon hasonló volt, jelezve, hogy a növényi kivonatok ugyanolyan hatásosak voltak, mint az akarbóz, a posztprandiális hiperglikémia enyhítésére (17. ábra). 


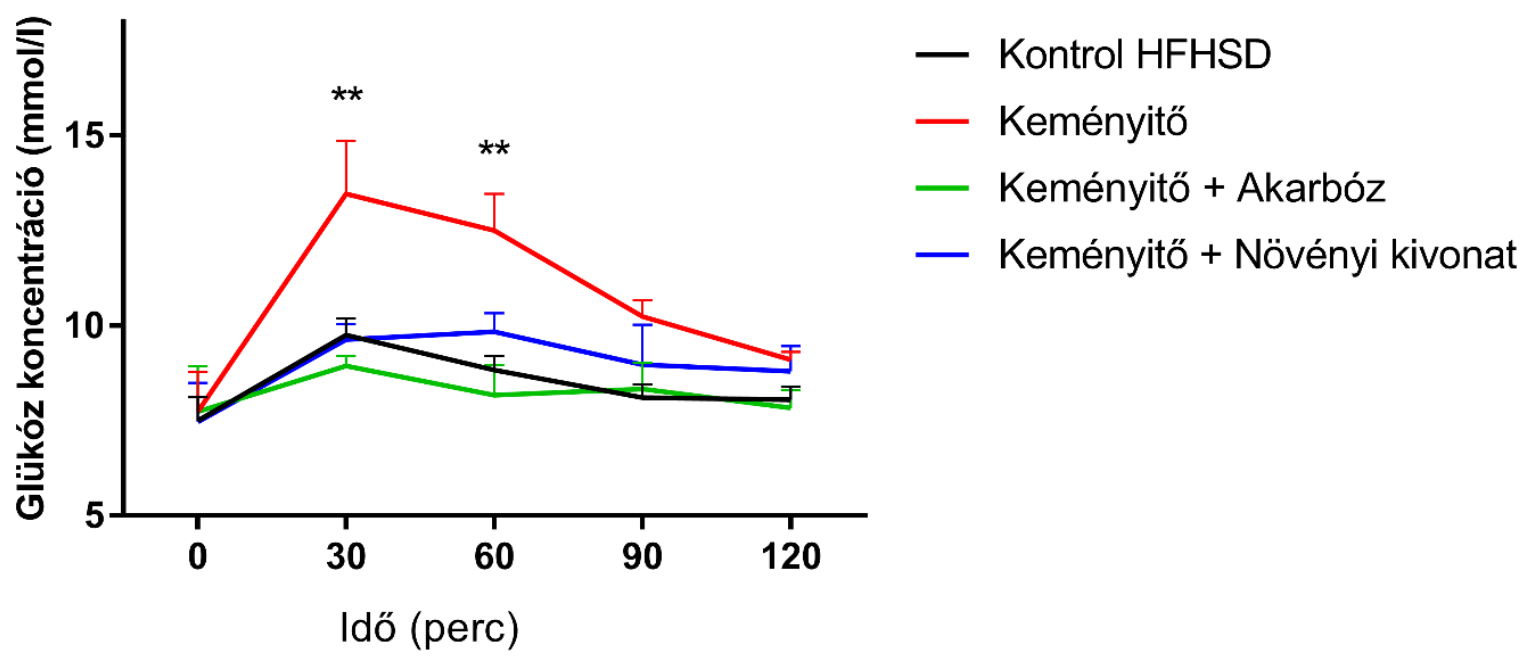

16. ábra Nem diabéteszes C57BL6 kontroll egerek vércukor koncentrációja. Középérték \pm SEM. ** $\mathrm{P}<0,01$ keményítő + növényi kivonat vs. keményítő *** $\mathrm{P}<0,001$ keményítő + növényi kivonat vs. keményítő.

\section{Prediabéteszes C57B16 egerek}

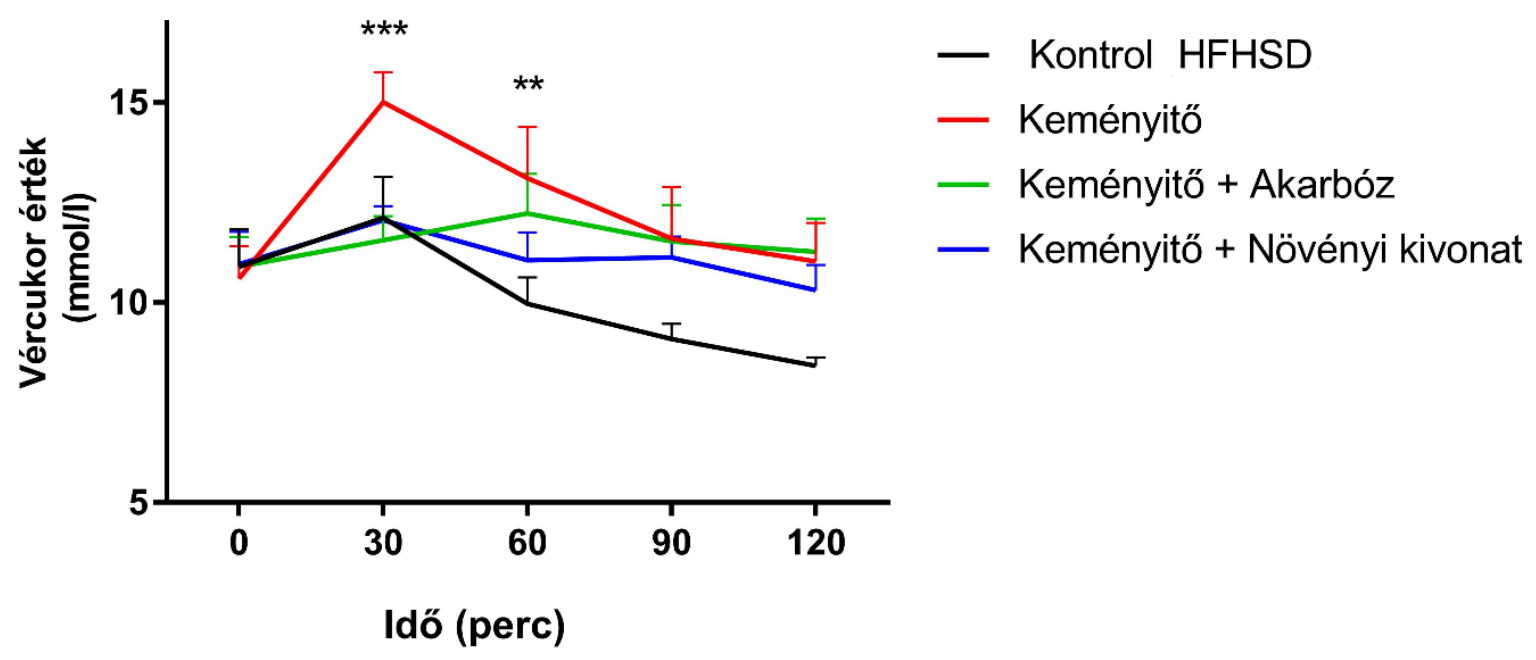

17. ábra Prediabéteszes C57BL6 egerek vércukor szintje. Középérték $\pm \mathrm{SEM}$. ** $\mathrm{P}<0,01$ keményítő + növényi kivonat vs. keményítő *** $\mathrm{P}<0,001$ keményítő + növényi kivonat vs. keményítő. 


\section{9 Értékelés}

Az értekezésben beszámolunk arról, hogy az általunk alkalmazott növényi kivonatok hatékonyan enyhítik az oldható kukoricakeményítő által indukált "posztprandiális" vércukorszint emelkedést normál egerekben és a hiperglikémiát prediabetikus és STZ indukált cukorbetegekben. Ez a hatás valószínüleg az áfonya a szeder és az erdei szamóca leveleiből származó vízoldható extraktumok által az $\alpha$-amiláz és az $\alpha$-glikozidáz enzimek gátlásán keresztül valósul meg. A cukorbetegség első tünete az étkezés utáni kiemelkedően magas vércukorszint. A szervezetbe kerülő komplex szénhidrátokat és oligoszacharidokat glikozidázokkal, például $\alpha$-amilázzal és $\alpha$-glükozidázokkal emésztjük meg a vékonybélben, ahol egyszerü cukrokká alakul át és végül a keringésbe jut. Ez a glükózterhelés a vér glükóz szintjének emelkedését eredményezi, ami megfelelő inzulinválaszokat vált ki, hogy a glükóz koncentrációja a normál tartományban maradjon.

A metabolikus szindrómához társuló glükóz intolerancia és a prediabetikus cukorbetegeknél megfigyelt károsodott inzulin-szekréció, és a hosszantartó hiperglikémia, amely hozzájárul az oxidatív stresszel járó diabéteszes szövődményekhez (Matough, Budin et al. 2012). Ezért a posztprandiális hiperglikémia csökkentése a bél glükozidázok gátlásán keresztül reményeket keltő kezelési stratégia a cukorbetegség elleni küzdelemben (He, Shi et al. 2014). Vizsgálataink alátámasztják, hogy a pszeudotetraszacharid vegyület, az akarbóz, egy antidiabetikus gyógyszer, amely in vitro gátolja az $\alpha$-amiláz és az $\alpha$-glikozidáz aktivitást, és in vivo csökkenti a kukoricakeményítő által kiváltott vércukorszint emelkedését. Az akarbóznak sajnos azonban gyakori gyomor-bélrendszeri mellékhatásai vannak, mint például a hasmenés, a gyomorfájdalom. Esettanulmányokban súlyos májkárosodás és akut hepatitisek előfordulását is közölték (Dabhi, Bhatt et al. 2013). Ezzel szemben a gyógynövények $\alpha$-amiláz és $\alpha$ glükozidáz inhibitorainak kevésbé káros hatásai vannak (Kumar, Narwal et al. 2011, Satoh, Igarashi et al. 2015). Korábban számos természetes növényi eredetü antidiabetikus termékeket vizsgáltak, melyek egy része hatásos $\alpha$-glikozidáz és $\alpha$-amiláz inhibitor volt (Hung, Qian et al. 2012, Sompong, Muangngam et al. 2016). Az általunk vizsgált növényi kivonatok in vitro $\alpha-$ glükozidáz gátlásának középértékei $\mu \mathrm{g} / \mathrm{ml}$-es tartományba estek, amelyek szignifikánsan alacsonyabbak, mint a fekete tea levelek $28 \mathrm{mg} / \mathrm{ml} \mathrm{IC} 50$ értékei (Satoh, Igarashi et al. 2015) vagy a Zingiber $3 \mathrm{mg} / \mathrm{ml}$ gátló koncentrációi (Jo, Cho et al. 2016), de magasabbak, mint az ayurvédikus gyógyászatban cukorbetegségben használt gyógynövény a Saliac oblongata 4 $\mu \mathrm{g} / \mathrm{ml} \mathrm{IC}_{50}$ értéke (Li, Peng et al. 2004) és a Prunica granatum $1,8 \mu \mathrm{g} / \mathrm{ml} \mathrm{IC} \mathrm{I}_{50}$ értéke (Li, Wen 
et al. 2005). Az általunk kapott eredmények hasonlóak az eperfa levélkivonatról szóló gátlási adatokhoz (Kim, Kwon et al. 2011). Az in vitro vizsgálatokban már korábban kimutatták az eper és az áfonya gyümölcsök esetében az $\alpha$-glükozidáz és az $\alpha$-amiláz aktivitások gátlását (McDougall, Kulkarni et al. 2008, Boath, Stewart et al. 2012), de a vizsgálatainkban azonban igazoltuk, hogy az eper, az áfonya és a szeder levélkivonatai szintén hatásosak az $\alpha$-glükozidáz és az $\alpha$-amiláz enzim aktivitásának in vitro gátlásában. Sajnálatos módon, a korábban közölt eredményeket nehéz összehasonlítani, mert különböző típusú szubsztrátokat, mérési- és extrakciós módszereket alkalmaztak az egyes forrásokban.

Az antioxidáns hatás magában foglalja a sejtek és a celluláris struktúrák elleni védelmet különösen a káros oxigén és a nitrogén szabad gyökök ellen. A szervezetünk saját antioxidatív rendszerei közé a következő enzimek tartoznak: a szuperoxid dizmutáz (EC 1.15.1.1.), kataláz (EC 1.11.1.6.), és a glutation-peroxidáz (EC 1.11.1.9.). A nem enzimatikus szubsztrátok közé tartozik a C-vitamin (L-aszkorbinsav), A-vitamin (retinol), E-vitamin (tokoferol), flavonoidok. Néhány biomolekulát és biológiailag aktív, klinikailag szignifikáns vegyületet, mint például a transzferrint, ferritint, laktoferrint, cöruloplazmint, haptoglobint és a húgysavat is antioxidánsnak tekinthetjük.

A civilizációs betegségek kialakulása révén az antioxidánsok és antioxidáns kapacitás mérése egyre inkább fontossá vált, hogy ilyen szempontból alaposabban megismerjük az egészséges élelmiszereket és azok összetevőit (Skerrett, Willett 2010). A PCL módszert elsőként Popov és Lewin (Popov, Lewin 1999) írta le és Langley-Evans (Langley-Evans 2000) és a Robinson (Robinson, Maxwell et al. 1997) tanulmányozták a fekete és zöld teák antioxidáns kapacitásának mérésénél. Több tanulmány megerősíti, hogy az oxidatív stressz hozzájárul a cukorbetegség hatására kialakuló szövődményéhez beleértve a makro és mikrovaszkuláris problémákat. Ezért a magas antioxidáns hatású vegyületek kedvezően befolyásolják a diabétesz szövődményeinek a kezelését (Rahimi, Nikfar et al. 2005, Giacco, Brownlee 2010). Ezen hatóanyagok hipoglikémiás, lipid-csökkentő és antioxidáns hatása nagyon ígéretes lehet a cukorbetegség kezelésében és a szív- és érrendszeri szövődmények megelőzésében (Umeno, Horie et al. 2016).

A levélkivonatokra nem csak úgy tekinthetünk, mint a gyümölcs olcsó alternatívái, hanem mint nagyobb mennyiségü fenolos vegyületet tartalmazó értékes növényi részek, amelyek anti-hiperglikémiás hatásokhoz kapcsolódnak. A bogyós gyümölcsök leveleinek kivonatai befolyásolják a vércukorszintet az egészséges, a prediabetikus és a diabéteszes egerekben is. A szénhidrátban és zsírban gazdag étrend túlzott súlygyarapodást és glükóz toleranciát okoz az egereknél, és hasonlóan, mint az embereknél prediabetikus állapotot hoz 
létre. Ebben a szakaszban az éhgyomri glükóz szintek már megemelkednek és magasabb csúcs koncentrációt érnek el a szénhidrát terhelés után, de a kiindulási értékhez visszatérnek. Ezzel szemben a STZ-kezelt egerekben a hasnyálmirigy- $\beta$ sejt funkció szignifikánsan romlott úgy, mint a diabéteszes betegek esetében, ezért hasonló módon, magas vagy emelkedett a kiindulási vércukor koncentráció és hosszú ideig tartó magas vércukorszint jellemzi. A vízben oldódó kukoricakeményítő intragasztrikus adagolása a vércukorszint emelkedését eredményezi az egereknél az összes kísérleti csoportban, de a glikémiás csúcs a STZ-diabéteszes csoportban volt a legmagasabb. A cukorbeteg egyedeknél a növényi kivonatok az akarbózhoz hasonlóan enyhítik a keményítő által kiváltott vércukorszint emelkedést, amely nem különbözik jelentősen azoktól, az értékektől, amelyeket a csak vivőanyaggal kezelt állatoknál tapasztalhattunk. A jelenlegi in vitro és in vivo adatok kombinációja azt sugallja, hogy a növényi kivonatok antihiperglikémiás hatása összefügg a bélben lévő $\alpha$-glükozidáz és $\alpha$-amiláz gátlásával, azonban az endogén glükóz termelést, a glükóz felvétel stimulálását és /vagy az inzulinszekréció fokozódását valamint az aktivitást szintén figyelembe kell venni, mint az antidiabetikus hatás okait. Például a fekete áfonya kivonatok nemcsak gátolták az $\alpha$-glükozidázt, hanem növelték az inzulinérzékenységet az AMP-tal aktivált protein kináz (AMPK) aktiválásával és a glükóz transzporter 4 (GLUT4) felszabadulását okozzák a fehér zsírszövetben és vázizomban. Ezt az aktivációt a glükóz termelés és a zsírtartalom elnyomása kíséri (Takikawa, Inoue et al. 2010). A szeder levélkivonat csökkentette a bazális (nem stimulált) vércukorszintet normál és STZkezelt patkányokban, ami a bél glükóz felvételének gátlását feltételezi (Jouad, Maghrani et al. 2002a, Verma, Gangrade et al. 2014) Az epergyümölcs vizes kivonata gátolta mind az $\alpha$-amiláz, mind az $\alpha$-glükozidáz aktivitást (Cheplick, Kwon et al. 2010), míg egy klinikai vizsgálat azt mutatta, hogy az eper polifenol beadását követően javult az inzulinérzékenység (Paquette, Medina Larque et al. 2017).

A növényi kivonatok legfontosabb biológiailag aktív összetevőit általában jól tolerálják az emlős szervezetek. Például a szeder kivonat közölt $\mathrm{LD}_{50}$ értéke $8,1 \mathrm{~g} / \mathrm{tstkg}$, jóval magasabb, mint sok toxikus növény esetében (Jouad, Maghrani et al. 2002a). A H9c2 patkány embrionális szívizomsejtjein valós idejü sejtes elektronikus érzékelési tesztet alkalmazó in vitro vizsgálatok azt is jelzik, hogy a különböző növényi kivonatok nem toxikusak az $1 \mathrm{mg} / \mathrm{ml}$-ig terjedő dózistartományban. Kísérleteinkben nem tapasztaltunk akut in vivo toxicitást az egereknél az 1200 mg/tstkg növényi kivonat alkalmazását követően sem. Számos aktív hatóanyagot izoláltak növényekből az emlősök $\alpha$-amiláz és $\alpha$-glükozidáz potenciális inhibitoraként, mint például a flavonoidok, alkaloidok, terpenoidok, antocianinok, glikozidok, és fenolos vegyületek (Kumar, 
Narwal et al. 2011). A kiválasztott növényi keverékek nagy gátlóhatást mutattak az $\alpha$-amiláz és az $\alpha$-glükozidáz enzimekre az in vitro tesztekben.

Az étkezés utáni vércukorszint szabályozása kulcsfontosságú tényező a cukorbetegséggel kapcsolatos kardiovaszkuláris komplikációk kezelésében (Pitocco, Tesauro et al. 2013). Korábbi tanulmányok kimutatták, hogy az eper- és áfonya levélben lévő vízoldható kivonat magas antioxidáns tulajdonságokkal rendelkező vegyületeket tartalmaz, például flavonoidokat és kvercetint, ami azt sugallta, hogy a kiválasztott gyógynövények bejuttatása segít a ROS-eredetü kóros mellékhatások kivédésében, a diabéteszes betegekben. A kvercetin önmagában is hatékony antioxidáns, elsősorban glikozidok vagy glükuronidok formájában, amelyek a májban keletkeznek. A kvercetin gátolja a xantin oxidáz és a lipoxigenáz aktivitását, ezáltal csökkenti a ROS képződést. Így elmondható, hogy a vércukorszintre gyakorolt kedvező hatásuk mellett a növényi kivonatok alkalmasak az oxidatív stressz csökkentésére is.

Összefoglalva, az $\alpha$-glükozidázzal szembeni magas gátló hatású, és az $\alpha$-amilázzal szembeni mérsékelt in vitro gátló hatással rendelkező kiválasztott növényi levél kivonatok kombinációja olyan keveréket eredményez, amely képes csökkenteni a vércukorszintek "posztprandiális" emelkedését egészséges kontroll-, prediabetikus- és diabetikus egereknél. A növényi kivonatok nem toxikusak, és nincs nyilvánvaló mellékhatásuk, ezért, mint hatóanyagok potenciális jelöltek a hiperglikémia jövőbeni kezelésére a 2-es típusú cukorbetegségben. 


\section{Következtetések}

1. Az irodalomból ismert nyolc gyógynövényt választottunk ki, amelyek glikozid-hidroláz aktivitásait in vitro teszteltük. A növényi kivonatok dózis függően gátolták az $\alpha$-amiláz aktivitását. $\mathrm{Az}$ egyes kivonatokhoz tartozó $\mathrm{IC}_{50}$ értéket meg határoztuk. A kiválasztott növények közül az erdei szamóca kivonatának volt a legalacsonyabb $\mathrm{IC}_{50}$ értéke miközben az áfonya és a szeder $\mathrm{IC}_{50}$ értéke szignifikánsan magasabb volt.

2. Új érzékeny HPLC módszert dolgoztunk ki az $\alpha$-amiláz gátlásának a mérésére. A HPLC alkalmazásával a komponensek elválasztása és mennyiségi meghatározása lehetséges és az adatokból a reakciók sebessége kiszámítható. Olyan szintetikus szubsztrátot hoztunk létre mely jobb kötést alakít ki az amiláz enzim aktív centrumával ezáltal jobban tudja modellezni a természetes viszonyokat. A CNP-G7 szintézisénél kialakított $\beta$-konfiguráció megvédi a szubsztrátot az amiláz hasításától így a kromofor csoport mindvégig a szubsztráton marad specifikussá téve a meghatározást. A szubsztrát tisztaságát folyadék kromatográfiával és MALDI-TOF MS készülékkel ellenőriztük.

3. Az állatkísérletek elött annak megállapítása érdekében, hogy a kipróbálásra szánt növényi hatóanyagok in vitro milyen hatást gyakorolnak a sejtekre citotoxicitási és citoprotekciós tesztet végeztünk. Az eredményeink azt mutatták, hogy egyik vizsgált növényi kivonatnak sem volt a citotoxikus hatása a vizsgált koncentrációtartományban.

4. A növényi komponensek hatóanyagait tömegspektrometriás módszerrel vizsgáltuk. A MALDI-TOF-MS eredményekkel több komponens összegképletét meghatároztuk és az irodalmi adatok alapján megadtuk a hozzájuk tartozó vegyületek lehetséges körét. A kivonatok az eredmények alapján nagy mennyiségü polifenolos vegyületeket tartalmaztak, amelyek közül legfontosabbak a tanninok, ellagtanninok, flavonoidok, és ezek származékai.

5. Az in vivo kísérleteknél mind a két cukorbeteg modellben teszteltük az általunk alkalmazott növényi keverék kombinációt. A kémiailag indukált diabétesz egy egyszerü és viszonylag olcsó modell a diabétesz patogenezisének a tanulmányozására rágcsálókban ezért az 1-es típusú cukorbetegség tanulmányozására a streptozotocin (STZ)- indukálásával hoztuk létre cukorbetegséget a CD1-es típusú egerekben. A 2-es típusú cukorbetegség tesztelésére HFHS tartalmú táplálék által előidézett prediabetikus elhízási modellt alkalmaztunk. Ezeket a kísérleteket hím C57BL6 egereken hajtottuk végre, amelyek hajlamosak a táplálék által kiváltott elhízásra. Mind a két cukorbeteg állat modellnél a farok vénából vett vérminta 
alapján a kezelést követően meghatároztuk a vércukor értéküket. Beszámolhattunk arról, hogy az általunk alkalmazott növényi kivonatok hatékonyan enyhítik a "posztprandiális" vércukorszint emelkedést normál egerekben és a hiperglikémiát prediabetikus és STZ indukált cukorbetegekben. A három növény keverékének alkalmazása megerősítette, hogy ezek a gyógynövények használhatóak az étkezés utáni hiperglikémia csökkentésére azáltal, hogy hatékonyan gátolják az $\alpha$-amiláz és $\alpha$-glükozidáz enzimeket. Továbbá biztonságosan alkalmazhatóak, mert nem merült fel citotoxikus hatás. A jelenlegi in vitro és in vivo adatok kombinációja azt sugallja, hogy a növényi kivonatok anti-hiperglikémiás hatása összefügg a bél $\alpha$-glükozidáz és az $\alpha$-amiláz gátlásával. A növényi kivonatok nem toxikusak, és nincs nyilvánvaló mellékhatásuk ezért célzott lehet a hiperglikémia lehetséges kiegészítő kezelésére a 2-es típusú cukorbetegségben vagy a metabolikus szindrómában. 


\section{Köszönetnyilvánítás}

Köszönetet szeretnék mondani Prof. Dr. Vágvölgyi Csaba Tanszékvezető egyetemi tanárnak, hogy a tanszékén végezhettem a Ph. D. dolgozatomat.

Köszönetet mondok Dr. Szekeres Andrásnak, témavezetőmnek technikai tanácsaival, és önzetlen segítségével segítette munkámat.

Köszönetet szeretnék mondani Dr. Pósa Anikó adjunktusnak témavetőmnek a dolgozat javításában a hasznos tanácsaiért, mindenkori segítőkészségért és építő kritikai megjegyzéseiért.

Köszönetemet szeretném kifejezni Dr. Gyémánt Gyöngyi egyetemi docensnek, hogy megismertette velem a szénhidrát kémia érdekes világát, a HPLC mérések módszerét, és folyamatos szakmai támogatásáért, és önzetlen segítségéért.

Hálás köszönetemet szeretném kifejezni Dr. Kovács Krisztina, Dr. Ferenczi Szilamér és Kővári Dóra a Magyar Tudományos Akadémia Kísérleti Orvostudományi Kutatóintézet Molekuláris Neuroendokrinológiai Kutatócsoportnál végzet in vivo állatkísérletekben végzet kimagasló munkájukért és önzetlen segítségükért.

Köszönetet szeretnék mondani Dr. Hackler László kutatás vezetőnek a citotoxikus és citoprotekciós vizsgálatokban nyújtott segítségért.

A dolgozattal kapcsolatos kutatásokat az „Új utak a természetes anyag alapú gyógyszerkutatásban: Rendszermetabolomikai megközelítések növényi és mikrobiális eredetü bioaktív terpenoidok felkutatására.” címü, GINOP-2.3.2-15-2016-00012 számú projekt támogatta. Valamint az infrastrukturális hátteret a GINOP-2.3.3-15-2016-00006 számú, „Mikrobiális génbankoz kapcsolódó integrált élettudományi és hatóanyag kutatás-fejlesztési centrum" címü pályázat biztosította.

EFOP-3.6.1-16-2016-00008 Intelligens élettudományi technológiák, módszertanok, alkalmazások fejlesztése és innovatív folyamatok, szolgáltatások kialakítása a szegedi tudásbázisra építve.

Tématámogatások: AzEMBERI ERŐFORRÁSOK MINISZTÉRIUMA ÚNKP-ÚNKP-17-4 KÓDSZÁMÚ

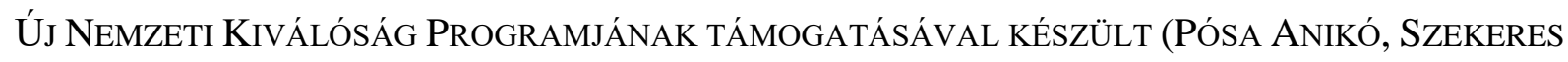
ANDRÁS) 


\section{Irodalomjegyzék}

Ph. Hg. VIII: European Pharmacopoeia; Magyar Gyógyszerkönyv. Ph. Eur. 4 edn.

ADEFEGHA, S.A. and OBOH, G., 2012. In vitro inhibition activity of polyphenol-rich extracts from Syzygium aromaticum (L.) Merr. \& Perry (Clove) buds against carbohydrate hydrolyzing enzymes linked to type 2 diabetes and $\mathrm{Fe}(2+)$-induced lipid peroxidation in rat pancreas. Asian Pacific journal of tropical biomedicine, 2(10), pp. 774-781.

ADEWOLE, S.O., CAXTON-MARTINS, E.A. and OJEWOLE, J.A., 2006. Protective effect of quercetin on the morphology of pancreatic beta-cells of streptozotocin-treated diabetic rats. African journal of traditional, complementary, and alternative medicines : AJTCAM, 4(1), pp. 64-74.

ALAGESAN K, RAGHUPATHI PK, SANKARNARAYANAN S, 2012. Amylase inhibitors: Potential source of anti-diabetic drug discovery from medicinal plants. International Journal of Pharmacy and Life Sciences, 3(2), pp. 1407-1412.

AL-NUMAIR, K.S., CHANDRAMOHAN, G., VEERAMANI, C. and ALSAIF, M.A., 2015. Ameliorative effect of kaempferol, a flavonoid, on oxidative stress in streptozotocin-induced diabetic rats. Redox report : communications in free radical research, 20(5), pp. 198-209.

ALONSO, R., CADAVID, I. and CALLEJA, J.M., 1980. A preliminary study of hypoglycemic activity of Rubus fruticosus. Planta Medica, Suppl, pp. 102-106.

AMINE, A., EL HARRAD, L., ARDUINI, F., MOSCONE, D. and PALLESCHI, G., 2014. Analytical aspects of enzyme reversible inhibition. Talanta, 118, pp. 368-374.

ANDERSON, R.A., BROADHURST, C.L., POLANSKY, M.M., SCHMIDT, W.F., KHAN, A., FLANAGAN, V.P., SCHOENE, N.W. and GRAVES, D.J., 2004. Isolation and characterization of polyphenol type-A polymers from cinnamon with insulin-like biological activity. Journal of Agricultural and Food Chemistry, 52(1), pp. 65-70.

ANTOLAK, H., CZYZOWSKA, A. and KREGIEL, D., 2016. Black Currant (Ribes nigrum L.) and Bilberry (Vaccinium myrtillus L.) Fruit Juices Inhibit Adhesion of Asaia spp. BioMed research international, 2016, pp. 3671306.

BAGDONAITE, E., JAKSTAS, V., RAUDONIS, R. and JANULIS, V., 2013. Chlorogenic acid, rutin and hyperoside content in Fragaria vesca, F. viridis and F. moschata in Lithuania. Natural product research, 27(2), pp. 181-184.

BAILEY, C.J. and DAY, C., 1989. Traditional plant medicines as treatments for diabetes. Diabetes care, 12(8), pp. 553-564.

BEEJMOHUN, V., PEYTAVY-IZARD, M., MIGNON, C., MUSCENTE-PAQUE, D., DEPLANQUE, X., RIPOLL, C. and CHAPAL, N., 2014. Acute effect of Ceylon cinnamon extract on postprandial glycemia: alpha-amylase inhibition, starch tolerance test in rats, and 
randomized crossover clinical trial in healthy volunteers. BMC complementary and alternative medicine, 14, pp. 351-6882-14-351.

BOATH, A.S., STEWART, D. and MCDOUGALL, G.J., 2012. Berry components inhibit alpha-glucosidase in vitro: synergies between acarbose and polyphenols from black currant and rowanberry. Food Chemistry, 135(3), pp. 929-936.

BOEL, E., BRADY, L., BRZOZOWSKI, A.M., DEREWENDA, Z., DODSON, G.G., JENSEN, V.J., PETERSEN, S.B., SWIFT, H., THIM, L. and WOLDIKE, H.F., 1990. Calcium binding in alpha-amylases: an X-ray diffraction study at 2.1-A resolution of two enzymes from Aspergillus. Biochemistry, 29(26), pp. 6244-6249.

BONO, V.H.Jr, 1976. Review of mechanism of action studies of the nitrosoureas. Cancer treatment reports, 60(6), pp. 699-702.

BOOTS, A.W., HAENEN, G.R. and BAST, A., 2008. Health effects of quercetin: from antioxidant to nutraceutical. European journal of pharmacology, 585(2-3), pp. 325-337.

BOUWENS, L. and ROOMAN, I., 2005. Regulation of pancreatic beta-cell mass. Physiological Reviews, 85(4), pp. 1255-1270.

BRAYER, G.D., LUO, Y. and WITHERS, S.G., 1995. The structure of human pancreatic alpha-amylase at 1.8 A resolution and comparisons with related enzymes. Protein science : a publication of the Protein Society, 4(9), pp. 1730-1742.

BRAYER, G.D., SIDHU, G., MAURUS, R., RYDBERG, E.H., BRAUN, C., WANG, Y., NGUYEN, N.T., OVERALL, C.M. and WITHERS, S.G., 2000. Subsite mapping of the human pancreatic alpha-amylase active site through structural, kinetic, and mutagenesis techniques. Biochemistry, 39(16), pp. 4778-4791.

CAMEJO-RODRIGUES, J., ASCENSAO, L., BONET, M.A. and VALLES, J., 2003. An ethnobotanical study of medicinal and aromatic plants in the Natural Park of "Serra de Sao Mamede" (Portugal). Journal of ethnopharmacology, 89(2-3), pp. 199-209.

CHAO, C.Y., MONG, M.C., CHAN, K.C. and YIN, M.C., 2010. Anti-glycative and antiinflammatory effects of caffeic acid and ellagic acid in kidney of diabetic mice. Molecular nutrition \& food research, 54(3), pp. 388-395.

CHENG, A.Y. and FANTUS, I.G., 2005. Oral antihyperglycemic therapy for type 2 diabetes mellitus. CMAJ : Canadian Medical Association journal = journal de l'Association medicale canadienne, 172(2), pp. 213-226.

CHEPLICK, S., KWON, Y.I., BHOWMIK, P. and SHETTY, K., 2010. Phenolic-linked variation in strawberry cultivars for potential dietary management of hyperglycemia and related complications of hypertension. Bioresource technology, 101(1), pp. 404-413.

CHIASSON, J.L., JOSSE, R.G., GOMIS, R., HANEFELD, M., KARASIK, A., LAAKSO, M. and STOP-NIDDM TRAIL RESEARCH GROUP, 2002. Acarbose for prevention of type 2 diabetes mellitus: the STOP-NIDDM randomised trial. Lancet, 359(9323), pp. 2072-2077. 
COPELAND, R.A., 2013. Evaluation of enzyme inhibitors in drug discovery: a guide for medicinal chemists and pharmacologists. John Wiley \& Sons.

COSKUN, O., KANTER, M., KORKMAZ, A. and OTER, S., 2005. Quercetin, a flavonoid antioxidant, prevents and protects streptozotocin-induced oxidative stress and beta-cell damage in rat pancreas. Pharmacological research, 51(2), pp. 117-123.

DABHI, A.S., BHATT, N.R. and SHAH, M.J., 2013. Voglibose: An Alpha Glucosidase Inhibitor. Journal of Clinical and Diagnostic Research : JCDR, 7(12), pp. 3023-3027.

D'AVILA FARIAS, M., OLIVEIRA, P.S., DUTRA, F.S., FERNANDES, T.J., DE PEREIRA, C.M., DE OLIVEIRA, S.Q., STEFANELLO, F.M., LENCINA, C.L. and BARSCHAK, A.G., 2014. Eugenol derivatives as potential anti-oxidants: is phenolic hydroxyl necessary to obtain an effect? The Journal of pharmacy and pharmacology, 66(5), pp. 733-746.

DEEDS, M., ANDERSON, J., ARMSTRONG, A., GASTINEAU, D., HIDDINGA, H., JAHANGIR, A., EBERHARDT, N. and KUDVA, Y., 2011. Single Dose Streptozotocin Induced Diabetes: Considerations for Study Design in Islet Transplantation Models. Laboratory animals, 45(3), pp. 131-140.

DEL BUBBA, M., CHECCHINI, L., CHIUMINATTO, U., DOUMETT, S., FIBBI, D. and GIORDANI, E., 2012. Liquid chromatographic/electrospray ionization tandem mass spectrometric study of polyphenolic composition of four cultivars of Fragaria vesca L. berries and their comparative evaluation. Journal of mass spectrometry : JMS, 47(9), pp. 1207-1220.

DHURIA, R.S., SINGH, G., KAUR, A., KAUR, R. and KAUR, T., 2015. Current status and patent prospective of animal models in diabetic research. Advanced Biomedical Research, 4, pp. 10.4103/2277-9175.157847.

DING, L., JIN, D. and CHEN, X., 2010. Luteolin enhances insulin sensitivity via activation of PPARgamma transcriptional activity in adipocytes. The Journal of nutritional biochemistry, 21(10), pp. 941-947.

DUFRANE, D., VAN STEENBERGHE, M., GUIOT, Y., GOEBBELS, R.M., SALIEZ, A. and GIANELLO, P., 2006. Streptozotocin-induced diabetes in large animals (pigs/primates): role of GLUT2 transporter and beta-cell plasticity. Transplantation, 81(1), pp. 36-45.

DUTTA T, JANA M, PAHARI PR, BHATTACHARYA T, 2006. The effect of temperature, $\mathrm{pH}$, and salt on amylase in Heliodiaptomus viduus (Gurney) (Crustacea: Copepoda: Calanoida). Turkish Journal of Zoology, 30(2), pp. 187-192.

EID, H.M., NACHAR, A., THONG, F., SWEENEY, G. and HADDAD, P.S., 2015. The molecular basis of the antidiabetic action of quercetin in cultured skeletal muscle cells and hepatocytes. Pharmacognosy magazine, 11(41), pp. 74-81.

EILEEN DOLAN, M., 1997. Inhibition of DNA repair as a means of increasing the antitumor activity of DNA reactive agents.

ELŐDI, P., ed, 1980. Biokémia. Budapest: Akadémia kiadó. 
FARIA, A. and PERSAUD, S.J., 2017. Cardiac oxidative stress in diabetes: Mechanisms and therapeutic potential. Pharmacology \& therapeutics, 172, pp. 50-62.

FEDERIUK, I.F., CASEY, H.M., QUINN, M.J., WOOD, M.D. and WARD, W.K., 2004. Induction of type-1 diabetes mellitus in laboratory rats by use of alloxan: route of administration, pitfalls, and insulin treatment. Comparative medicine, 54(3), pp. 252-257.

FERRER, J.L., AUSTIN, M.B., STEWART, C.,Jr and NOEL, J.P., 2008. Structure and function of enzymes involved in the biosynthesis of phenylpropanoids. Plant Physiology and Biochemistry: PPB / Societe francaise de physiologie vegetale, 46(3), pp. 356-370.

GAO, J., XU, P., WANG, Y., WANG, Y. and HOCHSTETTER, D., 2013. Combined effects of green tea extracts, green tea polyphenols or epigallocatechin gallate with acarbose on inhibition against alpha-amylase and alpha-glucosidase in vitro. Molecules (Basel, Switzerland), 18(9), pp. 11614-11623.

GASPEROTTI, M., MASUERO, D., GUELLA, G., PALMIERI, L., MARTINATTI, P., POJER, E., MATTIVI, F. and VRHOVSEK, U., 2013. Evolution of ellagitannin content and profile during fruit ripening in Fragaria spp. Journal of Agricultural and Food Chemistry, 61(36), pp. 8597-8607.

GIACCO, F. and BROWNLEE, M., 2010. Oxidative stress and diabetic complications. Circulation research, 107(9), pp. 1058-1070.

GIAMPIERI, F., ALVAREZ-SUAREZ, J.M., MAZZONI, L., FORBES-HERNANDEZ, T.Y., GASPARRINI, M., GONZALEZ-PARAMAS, A.M., SANTOS-BUELGA, C., QUILES, J.L., BOMPADRE, S., MEZZETTI, B. and BATTINO, M., 2014. An anthocyaninrich strawberry extract protects against oxidative stress damage and improves mitochondrial functionality in human dermal fibroblasts exposed to an oxidizing agent. Food \& function, 5(8), pp. 1939-1948.

GIN, H., RIGALLEAU, V., CAUBET, O., MASQUELIER, J. and AUBERTIN, J., 1999. Effects of red wine, tannic acid, or ethanol on glucose tolerance in non-insulin-dependent diabetic patients and on starch digestibility in vitro. Metabolism: clinical and experimental, 48(9), pp. 1179-1183.

GRAHAM, M.L., JANECEK, J.L., KITTREDGE, J.A., HERING, B.J. and SCHUURMAN, H.J., 2011. The streptozotocin-induced diabetic nude mouse model: differences between animals from different sources. Comparative medicine, 61(4), pp. 356-360.

GROOT, P.C., BLEEKER, M.J., PRONK, J.C., ARWERT, F., MAGER, W.H., PLANTA, R.J., ERIKSSON, A.W. and FRANTS, R.R., 1988. Human pancreatic amylase is encoded by two different genes. Nucleic acids research, 16(10), pp. 4724.

GUDEJ,Jan and TOMCZYK,Michal, 2004. Determination of Flavonoids, Tannins and Ellagic acid in leaves fromRubus L. species. Volume 27, Issue 11, pp 1114-1119.

GUDEJ,Jan and TOMCZYK,Michal, Determination of Flavonoids, Tannins and Ellagic acid in leaves fromRubus L. species. 
GYEMANT, G., KANDRA, L., NAGY, V. and SOMSAK, L., 2003. Inhibition of human salivary alpha-amylase by glucopyranosylidene-spiro-thiohydantoin. Biochemical and biophysical research communications, 312(2), pp. 334-339.

HAKKINEN, S.H., KARENLAMPI, S.O., HEINONEN, I.M., MYKKANEN, H.M. and TORRONEN, A.R., 1999. Content of the flavonols quercetin, myricetin, and kaempferol in 25 edible berries. Journal of Agricultural and Food Chemistry, 47(6), pp. 2274-2279.

HAO, H.H., SHAO, Z.M., TANG, D.Q., LU, Q., CHEN, X., YIN, X.X., WU, J. and CHEN, H., 2012. Preventive effects of rutin on the development of experimental diabetic nephropathy in rats. Life Sciences, 91(19-20), pp. 959-967.

HE, K., SHI, J.C. and MAO, X.M., 2014. Safety and efficacy of acarbose in the treatment of diabetes in Chinese patients. Therapeutics and Clinical Risk Management, 10, pp. 505-511.

HELMSTADTER, A., 2012. Antidiabetic medicinal plants--between phytotherapy and lead structure research. Pharmacy in history, 54(4), pp. 99-108.

HELMSTADTER, A. and SCHUSTER, N., 2010. Vaccinium myrtillus as an antidiabetic medicinal plant--research through the ages. Die Pharmazie, 65(5), pp. 315-321.

HOKKANEN, J., MATTILA, S., JAAKOLA, L., PIRTTILA, A.M. and TOLONEN, A., 2009. Identification of phenolic compounds from lingonberry (Vaccinium vitis-idaea L.), bilberry (Vaccinium myrtillus L.) and hybrid bilberry (Vaccinium x intermedium Ruthe L.) leaves. Journal of Agricultural and Food Chemistry, 57(20), pp. 9437-9447.

HOLLMAN, P.C., DE VRIES, J.H., VAN LEEUWEN, S.D., MENGELERS, M.J. and KATAN, M.B., 1995. Absorption of dietary quercetin glycosides and quercetin in healthy ileostomy volunteers. The American Journal of Clinical Nutrition, 62(6), pp. 1276-1282.

HUNG, H.Y., QIAN, K., MORRIS-NATSCHKE, S.L., HSU, C.S. and LEE, K.H., 2012. Recent discovery of plant-derived anti-diabetic natural products. Natural product reports, 29(5), pp. 580-606.

HUNYADI, A., MARTINS, A., HSIEH, T.J., SERES, A. and ZUPKÃ³ I., 2012a. Chlorogenic Acid and Rutin Play a Major Role in the In Vivo Anti-Diabetic Activity of Morus alba Leaf Extract on Type II Diabetic Rats. PLoS ONE, 7(11), pp. e50619. doi:10.1371/journal.pone.0050619.

HUNYADI, A., MARTINS, A., HSIEH, T.J., SERES, A. and ZUPKO, I., 2012b.

Chlorogenic acid and rutin play a major role in the in vivo anti-diabetic activity of Morus alba leaf extract on type II diabetic rats. PloS one, 7(11), pp. e50619.

IERI, F., MARTINI, S., INNOCENTI, M. and MULINACCI, N., 2013. Phenolic distribution in liquid preparations of Vaccinium myrtillus L. and Vaccinium vitis idaea L. Phytochemical analysis : PCA, 24(5), pp. 467-475.

IMAEDA, A., KANEKO, T., AOKI, T., KONDO, Y. and NAGASE, H., 2002. DNA damage and the effect of antioxidants in streptozotocin-treated mice. Food and Chemical Toxicology, 40(7), pp. 979-987. 
ITO, M., KONDO, Y., NAKATANI, A., HAYASHI, K. and NARUSE, A., 2001. Characterization of low dose streptozotocin-induced progressive diabetes in mice. Environmental toxicology and pharmacology, 9(3), pp. 71-78.

JANSSON, L., EIZIRIK, D.L., PIPELEERS, D.G., BORG, L.A., HELLERSTROM, C. and ANDERSSON, A., 1995. Impairment of glucose-induced insulin secretion in human pancreatic islets transplanted to diabetic nude mice. The Journal of clinical investigation, 96(2), pp. 721-726.

JO, S.H., CHO, C.Y., LEE, J.Y., HA, K.S., KWON, Y.I. and APOSTOLIDIS, E., 2016. In vitro and in vivo reduction of post-prandial blood glucose levels by ethyl alcohol and water Zingiber mioga extracts through the inhibition of carbohydrate hydrolyzing enzymes. $B M C$ complementary and alternative medicine, 16, pp. 111-016-1090-4.

JOUAD, H., MAGHRANI, M. and EDDOUKS, M., 2002a. Hypoglycaemic effect of Rubus fructicosis L. and Globularia alypum L. in normal and streptozotocin-induced diabetic rats. Journal of ethnopharmacology, 81(3), pp. 351-356.

JOUAD, H., MAGHRANI, M. and EDDOUKS, M., 2002b. Hypoglycaemic effect of Rubus fructicosis L. and Globularia alypum L. in normal and streptozotocin-induced diabetic rats. Journal of ethnopharmacology, 81(3), pp. 351-356.

JUN, H., BAE, H.Y., LEE, B.R., KOH, K.S., KIM, Y.S., LEE, K.W., KIM, H. and YOON, J., 1999. Pathogenesis of non-insulin-dependent (type II) diabetes mellitus (NIDDM) - genetic predisposition and metabolic abnormalities. Advanced Drug Delivery Reviews, 35(2-3), pp. 157-177.

JUNG, U.J., CHO, Y.Y. and CHOI, M.S., 2016. Apigenin Ameliorates Dyslipidemia, Hepatic Steatosis and Insulin Resistance by Modulating Metabolic and Transcriptional Profiles in the Liver of High-Fat Diet-Induced Obese Mice. Nutrients, 8(5), pp. 305.

doi:10.3390/nu8050305.

KANDRA L, 2003. $\alpha$-Amylases of medical and industrial importance. Journal of Molecular Structure, , pp. 666-667-487-498.

KANDRA, L., GYEMANT, G., ZAJACZ, A. and BATTA, G., 2004. Inhibitory effects of tannin on human salivary alpha-amylase. Biochemical and biophysical research communications, 319(4), pp. 1265-1271.

KANDRA, L., REMENYIK, J., BATTA, G., SOMSAK, L., GYEMANT, G. and PARK, K.H., 2005. Enzymatic synthesis of a new inhibitor of alpha-amylases: acarviosinylisomaltosyl-spiro-thiohydantoin. Carbohydrate research, 340(7), pp. 1311-1317.

KARUNANAYAKE, E.H., HEARSE, D.J. and MELLOWS, G., 1976. Streptozotocin: its excretion and metabolism in the rat. Diabetologia, 12(5), pp. 483-488.

KAZUMI, T., YOSHINO, G., FUJII, S. and BABA, S., 1978. Tumorigenic action of streptozotocin on the pancreas and kidney in male Wistar rats. Cancer research, 38(7), pp. 2144-2147. 
KHAN, A., ZAMAN, G. and ANDERSON, R.A., 2009. Bay leaves improve glucose and lipid profile of people with type 2 diabetes. Journal of clinical biochemistry and nutrition, 44(1), pp. 52-56.

KIM, G.N., KWON, Y.I. and JANG, H.D., 2011. Mulberry leaf extract reduces postprandial hyperglycemia with few side effects by inhibiting alpha-glucosidase in normal rats. Journal of medicinal food, 14(7-8), pp. 712-717.

KIM, J.H., KANG, M.J., CHOI, H.N., JEONG, S.M., LEE, Y.M. and KIM, J.I., 2011. Quercetin attenuates fasting and postprandial hyperglycemia in animal models of diabetes mellitus. Nutrition research and practice, 5(2), pp. 107-111.

KIM, M.J., LEE, S.B., LEE, H.S., LEE, S.Y., BAEK, J.S., KIM, D., MOON, T.W., ROBYT, J.F. and PARK, K.H., 1999. Comparative study of the inhibition of alpha-glucosidase, alphaamylase, and cyclomaltodextrin glucanosyltransferase by acarbose, isoacarbose, and acarviosine-glucose. Archives of Biochemistry and Biophysics, 371(2), pp. 277-283.

KIM, S.H., HYUN, S.H. and CHOUNG, S.Y., 2006. Anti-diabetic effect of cinnamon extract on blood glucose in db/db mice. Journal of ethnopharmacology, 104(1-2), pp. 119-123.

KOBORI, M., MASUMOTO, S., AKIMOTO, Y. and OIKE, H., 2011. Chronic dietary intake of quercetin alleviates hepatic fat accumulation associated with consumption of a Westernstyle diet in C57/BL6J mice. Molecular nutrition \& food research, 55(4), pp. 530-540.

KOBORI, M., MASUMOTO, S., AKIMOTO, Y. and TAKAHASHI, Y., 2009. Dietary quercetin alleviates diabetic symptoms and reduces streptozotocin-induced disturbance of hepatic gene expression in mice. Molecular nutrition \& food research, 53(7), pp. 859-868.

KUMAR, S., NARWAL, S., KUMAR, V. and PRAKASH, O., 2011. alpha-glucosidase inhibitors from plants: A natural approach to treat diabetes. Pharmacognosy reviews, 5(9), pp. 19-29.

LANGLEY-EVANS, S.C., 2000. Antioxidant potential of green and black tea determined using the ferric reducing power (FRAP) assay. International journal of food sciences and nutrition, 51(3), pp. 181-188.

LE BERRE-ANTON, V., BOMPARD-GILLES, C., PAYAN, F. and ROUGE, P., 1997. Characterization and functional properties of the alpha-amylase inhibitor (alpha-AI) from kidney bean (Phaseolus vulgaris) seeds. Biochimica et biophysica acta, 1343(1), pp. 31-40.

LE MAY, C., CHU, K., HU, M., ORTEGA, C.S., SIMPSON, E.R., KORACH, K.S., TSAI, M.J. and MAUVAIS-JARVIS, F., 2006. Estrogens protect pancreatic beta-cells from apoptosis and prevent insulin-deficient diabetes mellitus in mice. Proceedings of the National Academy of Sciences of the United States of America, 103(24), pp. 9232-9237.

LEE, J.H., YANG, S.H., OH, J.M. and LEE, M.G., 2010. Pharmacokinetics of drugs in rats with diabetes mellitus induced by alloxan or streptozocin: comparison with those in patients with type I diabetes mellitus. The Journal of pharmacy and pharmacology, 62(1), pp. 1-23. 
LEITER, E.H., 1982. Multiple low-dose streptozotocin-induced hyperglycemia and insulitis in C57BL mice: influence of inbred background, sex, and thymus. Proceedings of the National Academy of Sciences of the United States of America, 79(2), pp. 630-634.

LENZEN, S., 2008. The mechanisms of alloxan-and streptozotocin-induced diabetes. Diabetologia, 51(2), pp. 216-226.

LI, Y., PENG, G., LI, Q., WEN, S., HUANG, T.H., ROUFOGALIS, B.D. and YAMAHARA, J., 2004. Salacia oblonga improves cardiac fibrosis and inhibits postprandial hyperglycemia in obese Zucker rats. Life Sciences, 75(14), pp. 1735-1746.

LI, Y., WEN, S., KOTA, B.P., PENG, G., LI, G.Q., YAMAHARA, J. and ROUFOGALIS, B.D., 2005. Punica granatum flower extract, a potent alpha-glucosidase inhibitor, improves postprandial hyperglycemia in Zucker diabetic fatty rats. Journal of ethnopharmacology, 99(2), pp. 239-244.

LIBERAL, J., FRANCISCO, V., COSTA, G., FIGUEIRINHA, A., AMARAL, M.T., MARQUES, C., GIRÃO, H., LOPES, M.C., CRUZ, M.T. and BATISTA, M.T., 2014. Bioactivity of Fragaria vesca leaves through inflammation, proteasome and autophagy modulation. Journal of ethnopharmacology, 158, Part A, pp. 113-122.

LIKE, A.A. and ROSSINI, A.A., 1976. Streptozotocin-induced pancreatic insulitis: new model of diabetes mellitus. Science (New York, N.Y.), 193(4251), pp. 415-417.

LO PIPARO, E., SCHEIB, H., FREI, N., WILLIAMSON, G., GRIGOROV, M. and CHOU, C.J., 2008. Flavonoids for controlling starch digestion: structural requirements for inhibiting human alpha-amylase. Journal of medicinal chemistry, 51(12), pp. 3555-3561.

LORENTZ, K., 1998. Approved recommendation on IFCC methods for the measurement of catalytic concentration of enzymes. Part 9. IFCC method for alpha-amylase (1,4-alpha-Dglucan 4-glucanohydrolase, EC 3.2.1.1). International Federation of Clinical Chemistry and Laboratory Medicine (IFCC). Committee on Enzymes. Clinical chemistry and laboratory medicine, 36(3), pp. 185-203.

LU, W., JUANG, J., HSU, B.R. and HUANG, H., 1998. Effects of high or low dose of streptozocin on pancreatic islets in C57BL/6 and C. B17-SCID mice, Transplantation proceedings 1998, Elsevier, pp. 609-610.

LUKIC, M.L., STOSIC-GRUJICIC, S. and SHAHIN, A., 1998. Effector mechanisms in lowdose streptozotocin-induced diabetes. Developmental immunology, 6(1-2), pp. 119-128.

MAHMOUD, M.F., HASSAN, N.A., EL BASSOSSY, H.M. and FAHMY, A., 2013. Quercetin Protects against Diabetes-Induced Exaggerated Vasoconstriction in Rats: Effect on Low Grade Inflammation. PLoS ONE, 8(5), pp. e63784. doi:10.1371/journal.pone.0063784.

MARTINI, S., D'ADDARIO, C., COLACEVICH, A., FOCARDI, S., BORGHINI, F., SANTUCCI, A., FIGURA, N. and ROSSI, C., 2009. Antimicrobial activity against Helicobacter pylori strains and antioxidant properties of blackberry leaves (Rubus ulmifolius) and isolated compounds. International journal of antimicrobial agents, 34(1), pp. 50-59. 
MARTZ, F., JAAKOLA, L., JULKUNEN-TIITTO, R. and STARK, S., 2010. Phenolic composition and antioxidant capacity of bilberry (Vaccinium myrtillus) leaves in Northern Europe following foliar development and along environmental gradients. Journal of chemical ecology, 36(9), pp. 1017-1028.

MATHISON, B.D., KIMBLE, L.L., KASPAR, K.L., KHOO, C. and CHEW, B.P., 2014. Consumption of cranberry beverage improved endogenous antioxidant status and protected against bacteria adhesion in healthy humans: a randomized controlled trial. Nutrition research (New York, N.Y.), 34(5), pp. 420-427.

MATOUGH, F.A., BUDIN, S.B., HAMID, Z.A., ALWAHAIBI, N. and MOHAMED, J., 2012. The Role of Oxidative Stress and Antioxidants in Diabetic Complications. Sultan Qaboos University Medical Journal, 12(1), pp. 5-18.

MCART, S.H., SPALINGER, D.E., KENNISH, J.M. and COLLINS, W.B., 2006. A modified method for determining tannin-protein precipitation capacity using accelerated solvent extraction (ASE) and microplate gel filtration. Journal of chemical ecology, 32(6), pp. 13671377.

MCDOUGALL, G.J., KULKARNI, N.N. and STEWART, D., 2008. Current developments on the inhibitory effects of berry polyphenols on digestive enzymes. BioFactors (Oxford, England), 34(1), pp. 73-80.

MENTREDDY, S.R., 2007. Medicinal plant species with potential antidiabetic properties. Journal of the science of food and agriculture, 87(5), pp. 743-750.

MOSCA, M., BONIGLIA, C., CARRATU, B., GIAMMARIOLI, S., NERA, V. and SANZINI, E., 2008. Determination of alpha-amylase inhibitor activity of phaseolamin from kidney bean (Phaseolus vulgaris) in dietary supplements by HPAEC-PAD. Analytica Chimica Acta, 617(1-2), pp. 192-195.

NAJAFIAN, M., EBRAHIM-HABIBI, A., YAGHMAEI, P., PARIVAR, K. and LARIJANI, B., 2010. Core structure of flavonoids precursor as an antihyperglycemic and antihyperlipidemic agent: an in vivo study in rats. Acta Biochimica Polonica, 57(4), pp. 553560 .

NAJDA, A., DYDUCH-SIEMINSKA, M., DYDUCH, J. and GANTNER, M., 2014. Comparative analysis of secondary metabolites contents in Fragaria vesca L. fruits. Annals of Agricultural and Environmental Medicine : AAEM, 21(2), pp. 339-343.

NAKAMURA, M., NAGAFUCHI, S., YAMAGUCHI, K. and TAKAKI, R., 1984. The role of thymic immunity and insulitis in the development of streptozocin-induced diabetes in mice. Diabetes, 33(9), pp. 894-900.

NEKVAPIL, T., KOPRIVA, V., BOUDNY, V., HOSTOVSKY, M., DVORAK, P. and MALOTA, L., 2012. Decrease in the Antioxidant Capacity in Beverages Containing Tea Extracts during Storage. The Scientific World Journal, 2012, pp. 10.1100/2012/361698. 
NEVES, J.M., MATOS, C., MOUTINHO, C., QUEIROZ, G. and GOMES, L.R., 2009. Ethnopharmacological notes about ancient uses of medicinal plants in Tras-os-Montes (northern of Portugal). Journal of ethnopharmacology, 124(2), pp. 270-283.

NIJVELDT, R.J., VAN NOOD, E., VAN HOORN, D.E., BOELENS, P.G., VAN NORREN, K. and VAN LEEUWEN, P.A., 2001. Flavonoids: a review of probable mechanisms of action and potential applications. The American Journal of Clinical Nutrition, 74(4), pp. 418-425.

NITURE, N.T., ANSARI, A.A. and NAIK, S.R., 2014. Anti-hyperglycemic activity of rutin in streptozotocin-induced diabetic rats: an effect mediated through cytokines, antioxidants and lipid biomarkers. Indian journal of experimental biology, 52(7), pp. 720-727.

OSZMIANSKI, J., NOWICKA, P., TELESZKO, M., WOJDYLO, A., CEBULAK, T. and OKLEJEWICZ, K., 2015. Analysis of Phenolic Compounds and Antioxidant Activity in Wild Blackberry Fruits. International journal of molecular sciences, 16(7), pp. 14540-14553.

OZSVARI, B., PUSKAS, L.G., NAGY, L.I., KANIZSAI, I., GYURIS, M., MADACSI, R., FEHER, L.Z., GERO, D. and SZABO, C., 2010. A cell-microelectronic sensing technique for the screening of cytoprotective compounds. International journal of molecular medicine, 25(4), pp. 525-530.

PAQUETTE, M., MEDINA LARQUE, A.S., WEISNAGEL, S.J., DESJARDINS, Y., MAROIS, J., PILON, G., DUDONNE, S., MARETTE, A. and JACQUES, H., 2017. Strawberry and cranberry polyphenols improve insulin sensitivity in insulin-resistant, nondiabetic adults: a parallel, double-blind, controlled and randomised clinical trial. The British journal of nutrition, 117(4), pp. 519-531.

PINTO MDA, S., DE CARVALHO, J.E., LAJOLO, F.M., GENOVESE, M.I. and SHETTY, K., 2010. Evaluation of antiproliferative, anti-type 2 diabetes, and antihypertension potentials of ellagitannins from strawberries (Fragaria $\mathrm{x}$ ananassa Duch.) using in vitro models. Journal of medicinal food, 13(5), pp. 1027-1035.

PITOCCO, D., TESAURO, M., ALESSANDRO, R., GHIRLANDA, G. and CARDILLO, C., 2013. Oxidative Stress in Diabetes: Implications for Vascular and Other Complications. International Journal of Molecular Sciences, 14(11), pp. 21525-21550.

POPOV, I. and LEWIN, G., 1999. Antioxidative homeostasis: characterization by means of chemiluminescent technique. Methods in enzymology, 300, pp. 437-456.

QIAN, M., NAHOUM, V., BONICEL, J., BISCHOFF, H., HENRISSAT, B. and PAYAN, F., 2001. Enzyme-catalyzed condensation reaction in a mammalian alpha-amylase. Highresolution structural analysis of an enzyme-inhibitor complex. Biochemistry, 40(25), pp. 7700-7709.

RAHIMI, R., NIKFAR, S., LARIJANI, B. and ABDOLLAHI, M., 2005. A review on the role of antioxidants in the management of diabetes and its complications. Biomedicine \& pharmacotherapy $=$ Biomedecine \& pharmacotherapie, 59(7), pp. 365-373.

RANA JENISH, H., PATEL, S.J. and SHAH, D.P., PHARMACOLOGICAL ACTIVITIES OF FRAGARIA VESCA: A REVIEW. Pharma Science Monitor, 7(2), pp. 132-138. 
RAO, Y.K., GEETHANGILI, M., FANG, S.H. and TZENG, Y.M., 2007. Antioxidant and cytotoxic activities of naturally occurring phenolic and related compounds: a comparative study. Food and chemical toxicology : an international journal published for the British Industrial Biological Research Association, 45(9), pp. 1770-1776.

RATNA WULAN, D., PRIYO UTOMO, E. and MAHDI, C., 2015. Antidiabetic Activity of Ruellia tuberosa L., Role of Ît-Amylase Inhibitor: In Silico, In Vitro, and In Vivo Approaches. Biochemistry Research International, 2015, pp. 10.1155/2015/349261.

RERUP, C.C., 1970. Drugs producing diabetes through damage of the insulin secreting cells. Pharmacological reviews, 22(4), pp. 485-518.

RIIHINEN, K., JAAKOLA, L., KARENLAMPI, S. and HOHTOLA, A., 2008. Organspecific distribution of phenolic compounds in bilberry (Vaccinium myrtillus) and 'northblue' blueberry (Vaccinium corymbosum x V. angustifolium). Food Chemistry, 110(1), pp. 156160.

ROBINSON, E.E., MAXWELL, S.R. and THORPE, G.H., 1997. An investigation of the antioxidant activity of black tea using enhanced chemiluminescence. Free radical research, 26(3), pp. 291-302.

ROBYT JF, 2005. Inhibition, activation, and stabilization of $\alpha$-amylase family enzymes. 16(Biologia Bratislava), pp. 17-26.

ROSAK, C. and MERTES, G., 2009. Effects of acarbose on proinsulin and insulin secretion and their potential significance for the intermediary metabolism and cardiovascular system. Current diabetes reviews, 5(3), pp. 157-164.

ROSENBLOOM, A.L., HOUSE, D.V. and WINTER, W.E., 1998. Non-insulin dependent diabetes mellitus (NIDDM) in minority youth: research priorities and needs. Clinical pediatrics, 37(2), pp. 143-152.

ROSS, J.A. and KASUM, C.M., 2002. Dietary flavonoids: bioavailability, metabolic effects, and safety. Annual Review of Nutrition, 22, pp. 19-34.

ROSSINI, A.A., LIKE, A.A., CHICK, W.L., APPEL, M.C. and CAHILL, G.F.,Jr, 1977. Studies of streptozotocin-induced insulitis and diabetes. Proceedings of the National Academy of Sciences of the United States of America, 74(6), pp. 2485-2489.

SAHA, S. and VERMA, R., 2012. Inhibitory potential of traditional herbs on alpha-amylase activity. Pharmaceutical Biology, 50(3), pp. 326-331.

SAHIN BASAK, S. and CANDAN, F., 2013. Effect of Laurus nobilis L. Essential Oil and its Main Components on alpha-glucosidase and Reactive Oxygen Species Scavenging Activity. Iranian journal of pharmaceutical research : IJPR, 12(2), pp. 367-379.

SALES, P.M., SOUZA, P.M., SIMEONI, L.A., MAGALHÃES, P.O. and SILVEIRA, D., 2012. $\alpha$-Amylase inhibitors: a review of raw material and isolated compounds from plant source. Journal of Pharmacy \& Pharmaceutical Sciences, 15(1), pp. 141-183. 
SATOH, T., IGARASHI, M., YAMADA, S., TAKAHASHI, N. and WATANABE, K., 2015. Inhibitory effect of black tea and its combination with acarbose on small intestinal alphaglucosidase activity. Journal of ethnopharmacology, 161, pp. 147-155.

SCANNAPIECO, F.A., TORRES, G. and LEVINE, M.J., 1993. Salivary alpha-amylase: role in dental plaque and caries formation. Critical reviews in oral biology and medicine : an official publication of the American Association of Oral Biologists, 4(3-4), pp. 301-307.

SHARMA, R., 2012. Enzyme inhibition: mechanisms and scope. INTECH Open Access Publisher.

SHESHALA, R., PEH, K.K. and DARWIS, Y., 2009. Preparation, characterization, and in vivo evaluation of insulin-loaded PLA-PEG microspheres for controlled parenteral drug delivery. Drug development and industrial pharmacy, 35(11), pp. 1364-1374.

SHI, T., ZHUANG, R., ZHOU, H., WANG, F., SHAO, Y. and CAI, Z., 2015. Effect of apigenin on protein expressions of PPARs in liver tissues of rats with nonalcoholic steatohepatitis. Zhonghua gan zang bing za zhi = Zhonghua ganzangbing zazhi $=$ Chinese journal of hepatology, 23(2), pp. 124-129.

SHOBANA, S., SREERAMA, Y.N. and MALLESHI, N.G., 2009. Composition and enzyme inhibitory properties of finger millet (Eleusine coracana L.) seed coat phenolics: Mode of inhibition of $\alpha$-glucosidase and pancreatic amylase. Food Chemistry, 115(4), pp. 1268-1273.

SINDHU S, In vitro studies on alpha amylase and alpha glucosidase inhibitory activities of selected plant extracts. European Journal of Experimental Biology, 2013, 3, pp. 128-132.

SINGH, J., DARTOIS, A. and KAUR, L., 2010. Starch digestibility in food matrix: a review. Trends in Food Science \& Technology, 21(4), pp. 168-180.

SKERRETT, P.J. and WILLETT, W.C., 2010. Essentials of Healthy Eating: A Guide. Journal of midwifery \& women's health, 55(6), pp. 492-501.

SOMPONG, W., MUANGNGAM, N., KONGPATPHARNICH, A., MANACHAROENLARP, C., AMORWORASIN, C., SUANTAWEE, T., THILAVECH, T. and ADISAKWATTANA, S., 2016. The inhibitory activity of herbal medicines on the keys enzymes and steps related to carbohydrate and lipid digestion. BMC Complementary and Alternative Medicine, 16, pp. 10.1186/s12906-016-1424-2.

STANLEY MAINZEN PRINCE, P. and KAMALAKKANNAN, N., 2006. Rutin improves glucose homeostasis in streptozotocin diabetic tissues by altering glycolytic and gluconeogenic enzymes. Journal of Biochemical and Molecular Toxicology, 20(2), pp. 96102.

SUN, J., LIU, W., MA, H., MARAIS, J.P.J., KHOO, C., DAIN, J.A., ROWLEY, D.C. and SEERAM, N.P., 2016. Effect of cranberry (Vaccinium macrocarpon) oligosaccharides on the formation of advanced glycation end-products. Journal of berry research, 6(2), pp. 149-158.

SUN, X., CHEN, R.C., YANG, Z.H., SUN, G.B., WANG, M., MA, X.J., YANG, L.J. and SUN, X.B., 2014. Taxifolin prevents diabetic cardiomyopathy in vivo and in vitro by 
inhibition of oxidative stress and cell apoptosis. Food and chemical toxicology : an international journal published for the British Industrial Biological Research Association, 63, pp. 221-232.

SWANSTON-FLATT, S.K., DAY, C., BAILEY, C.J. and FLATT, P.R., 1990. Traditional plant treatments for diabetes. Studies in normal and streptozotocin diabetic mice.

Diabetologia, 33(8), pp. 462-464.

SZKUDELSKI, T., 2001a. The mechanism of alloxan and streptozotocin action in B cells of the rat pancreas. Physiological research, 50(6), pp. 537-546.

SZKUDELSKI, T., 2001b. The mechanism of alloxan and streptozotocin action in B cells of the rat pancreas. Physiological research, 50(6), pp. 537-546.

TADERA, K., MINAMI, Y., TAKAMATSU, K. and MATSUOKA, T., 2006. Inhibition of alpha-glucosidase and alpha-amylase by flavonoids. Journal of nutritional science and vitaminology, 52(2), pp. 149-153.

TAKIKAWA, M., INOUE, S., HORIO, F. and TSUDA, T., 2010. Dietary anthocyanin-rich bilberry extract ameliorates hyperglycemia and insulin sensitivity via activation of AMPactivated protein kinase in diabetic mice. The Journal of nutrition, 140(3), pp. 527-533.

TESCH, G.H. and ALLEN, T.J., 2007. Rodent models of streptozotocin-induced diabetic nephropathy (Methods in Renal Research). Nephrology, 12(3), pp. 261-266.

TOBYN, G., DENHAM, A. and WHITELEGG, M., 2011. CHAPTER 26 - Rubus idaeus, raspberry. In: G. TOBYN, A. DENHAM and M. WHITELEGG, eds, Medical Herbs. Edinburgh: Churchill Livingstone, pp. 271-282.

TRUMBECKAITE, S., BERNATONIENE, J., MAJIENE, D., JAKSTAS, V., SAVICKAS, A. and TOLEIKIS, A., 2006. The effect of flavonoids on rat heart mitochondrial function. Biomedicine \& pharmacotherapy = Biomedecine \& pharmacotherapie, 60(5), pp. 245-248.

UMENO, A., HORIE, M., MUROTOMI, K., NAKAJIMA, Y. and YOSHIDA, Y., 2016. Antioxidative and Antidiabetic Effects of Natural Polyphenols and Isoflavones. Molecules (Basel, Switzerland), 21(6), pp. 10.3390/molecules21060708.

VAGIRI, M., CONNER, S., STEWART, D., ANDERSSON, S.C., VERRALL, S., JOHANSSON, E. and RUMPUNEN, K., 2015. Phenolic compounds in blackcurrant (Ribes nigrum L.) leaves relative to leaf position and harvest date. Food Chemistry, 172, pp. 135142.

VERHOEYEN, M.E., BOVY, A., COLLINS, G., MUIR, S., ROBINSON, S., DE VOS, C.H. and COLLIVER, S., 2002. Increasing antioxidant levels in tomatoes through modification of the flavonoid biosynthetic pathway. Journal of experimental botany, 53(377), pp. 2099-2106.

VERMA, R., GANGRADE, T., PUNASIYA, R. and GHULAXE, C., 2014. Rubus fruticosus (blackberry) use as an herbal medicine. Pharmacognosy reviews, 8(16), pp. 101-104. 
VESSAL, M., HEMMATI, M. and VASEI, M., 2003. Antidiabetic effects of quercetin in streptozocin-induced diabetic rats. Comparative biochemistry and physiology.Toxicology \& pharmacology : CBP, 135C(3), pp. 357-364.

VIVEK, K., 2010. Streptozotocin: an experimental tool in diabetes and alzheimer's disease (A-Review). Int J Pharma Res Dev, 2(1), pp. 1-7.

WANG HH, CHEN CL, JENG TL, SUNG JM, 2011. Comparisons of [alpha]-amylase inhibitors from seeds of common bean mutants extracted through three phase partitioning. Food Chemistry, 128, pp. 1066-1071.

WANG, S.Y. and LIN, H.S., 2000a. Antioxidant activity in fruits and leaves of blackberry, raspberry, and strawberry varies with cultivar and developmental stage. Journal of Agricultural and Food Chemistry, 48(2), pp. 140-146.

WANG, S.Y. and LIN, H.S., 2000b. Antioxidant activity in fruits and leaves of blackberry, raspberry, and strawberry varies with cultivar and developmental stage. Journal of Agricultural and Food Chemistry, 48(2), pp. 140-146.

WANG, Z. and GLEICHMANN, H., 1998. GLUT2 in pancreatic islets: crucial target molecule in diabetes induced with multiple low doses of streptozotocin in mice. Diabetes, 47(1), pp. 50-56.

WEIDE, L.G. and LACY, P.E., 1991. Low-dose streptozocin-induced autoimmune diabetes in islet transplantation model. Diabetes, 40(9), pp. 1157-1162.

WHITCOMB, D.C. and LOWE, M.E., 2007. Human pancreatic digestive enzymes. Digestive diseases and sciences, 52(1), pp. 1-17.

WILD, S., ROGLIC, G., GREEN, A., SICREE, R. and KING, H., 2004. Global prevalence of diabetes: estimates for the year 2000 and projections for 2030. Diabetes care, 27(5), pp. 10471053.

XIAO, J., NI, X., KAI, G. and CHEN, X., 2013. A review on structure-activity relationship of dietary polyphenols inhibiting alpha-amylase. Critical reviews in food science and nutrition, 53(5), pp. 497-506.

XU, Y., ZHANG, Y. and CHEN, M., 2006. Effective fractions of Rubus fruticosus leaf, its pharmaceutical composition and uses for prevention and treatment of diabetes. China, CN1788755, 21.

YAMAGISHI, S., NAKAMURA, K. and TAKEUCHI, M., 2005. Inhibition of postprandial hyperglycemia by acarbose is a promising therapeutic strategy for the treatment of patients with the metabolic syndrome. Medical hypotheses, 65(1), pp. 152-154.

YAMAGUCHI, R., TOKUNAGA, H., ISHIBASHI, M., ARAKAWA, T. and TOKUNAGA, M., 2011. Salt-dependent thermo-reversible alpha-amylase: cloning and characterization of halophilic alpha-amylase from moderately halophilic bacterium, Kocuria varians. Applied Microbiology and Biotechnology, 89(3), pp. 673-684. 
YAN, L., ZHANG, J.D., WANG, B., LV, Y.J., JIANG, H., LIU, G.L., QIAO, Y., REN, M. and GUO, X.F., 2013. Quercetin inhibits left ventricular hypertrophy in spontaneously hypertensive rats and inhibits angiotensin II-induced H9C2 cells hypertrophy by enhancing PPAR-gamma expression and suppressing AP-1 activity. PloS one, 8(9), pp. e72548.

ZANG, Y., ZHANG, L., IGARASHI, K. and YU, C., 2015. The anti-obesity and anti-diabetic effects of kaempferol glycosides from unripe soybean leaves in high-fat-diet mice. Food \& function, 6(3), pp. 834-841.

ZHANG, Y. and LIU, D., 2011. Flavonol kaempferol improves chronic hyperglycemiaimpaired pancreatic beta-cell viability and insulin secretory function. European journal of pharmacology, 670(1), pp. 325-332.

ZIA-UL-HAQ, M., RIAZ, M., DE FEO, V., JAAFAR, H.Z. and MOGA, M., 2014. Rubus fruticosus L.: constituents, biological activities and health related uses. Molecules (Basel, Switzerland), 19(8), pp. 10998-11029.

\section{3 Ábrajegyzék}

1. ábra $A z$ akarbóz szerkezete

2. ábra A vizsgált növények 10 g-nyi mennyiségből extrahálható anyagainak mennyisége .. 33

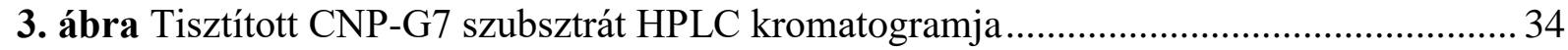

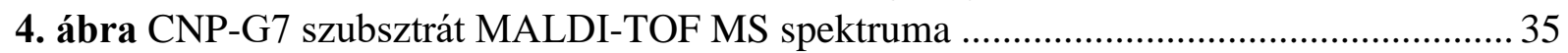

5. ábra A különböző szubsztrát koncentráció [S] mellett kapott reakció sebességek..............36

6. ábra A különböző időpontokban injektált minták kromatogramja................................... 37

7. ábra A CNP-G3 képződés reakciósebességének meghatározása ..................................... 37

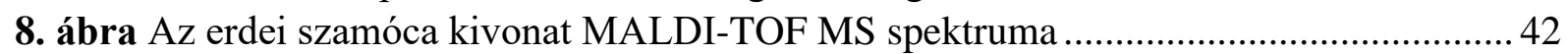

9. ábra A szeder kivonat MALDI-TOF MS spektruma ..................................................... 43

10. ábra Az áfonya kivonat MALDI-TOF MS spektruma ................................................... 43

11. ábra A növényi kivonatok hatása a $\mathrm{H} 9 \mathrm{c} 2$ sejtek életképességére. A. áfonya levél, B. szeder levél, C. erdei szamóca levél kivonatok. A szürke oszlopok jelölik a 24 h, a fekete oszlopok a 48 h inkubációs idő utáni leolvasást. A kezelt sejtek értékei: középérték $\pm \mathrm{SD}, \mathrm{Az}$ adatokat egymintás ANOVA-val, majd a Tukey post hoc tesztel értékeltük. Az eltéréseket *p $<0,05$ esetén tekintettük szignifikánsnak a kontrollhoz képest.

12. ábra A növényi kivonatok citoprotekciós hatásának vizsgálata. A. áfonya, B. szeder, $C$. erdei szamóca kivonatok. A kezeletlen kontroll (lila), a hidrogén-peroxiddal kezelt citoprotektív hatóanyag (világos kék, pozitív kontroll), a hidrogén-peroxiddal kezelt sejtek (sötétkék, negatív kontrol) tüntettük fel. A növényi extraktumok adatait piros $(1 \mathrm{mg} / \mathrm{ml})$ és zöld $(0,1 \mathrm{mg} / \mathrm{ml})$ színnel jelöltük.

13. ábra $A$ kontroll egerek $(\mathrm{CD} 1)$ vércukorszintjének változása. A középérték $\pm \mathrm{SEM}$ értékeket többszörös t-teszttel elemeztük. ${ }^{*} / * \mathrm{P}<0,05$ keményítö+növényi kivonat vs. keményítő.

14. ábra CD1 STZ indukált egér kezelés utáni 5. nap. A középérték $\pm S E M$ értékeket többszörös t-teszttel elemeztük. */**P $<0,05$ keményítő+növényi kivonat vs. keményítő. .... 52 
15. ábra CD1 STZ indukált egér kezelés utáni 10. nap. A középérték \pm SEM értékeket többszörös t-teszttel elemeztük. $* / * * \mathrm{P}<0,05$ keményítő+növényi kivonat vs. keményítő. .... 53 16. ábra Nem diabéteszes C57BL6 kontroll egerek vércukor koncentrációja. Középérték \pm SEM. ** $\mathrm{P}<0,01$ keményítő + növényi kivonat vs. keményítő *** $\mathrm{P}<0,001$ keményítő + növényi kivonat vs. keményítő.

17. ábra Prediabéteszes C57BL6 egerek vércukor szintje. Középérték \pm SEM. $* * ~ P<0,01$ keményítő + növényi kivonat vs. keményítő *** $\mathrm{P}<0,001$ keményítő + növényi kivonat vs. keményítő.

1. táblázat A vizsgált növények listája

2. táblázat Növények $\mathrm{IC}_{50}$ értékei $(\mu \mathrm{g} / \mathrm{ml})$ és relatív amiláz gátlásuk az akarbózhoz viszonyítva.

3. táblázat Növények $\mathrm{IC}_{50}$ értékei $(\mu \mathrm{g} / \mathrm{ml})$ és az $\alpha$-glükozidáz gátlás százalékos értékei....... 39

4. táblázat $A$ növények antioxidáns hatásai (átlag $\pm \mathrm{SD}$ ).

5. táblázat A növényi kivonatok MS-spektrumában azonosított vegyületek és a kapcsolódó 47 


\section{Magyar nyelvű összefoglaló}

A hiperglikémia kezelése nagyon fontos az olyan anyagcsere rendellenességek gyógyítása során mint például a 2-típusú diabétesz és a metabolikus szindróma. Az $\alpha$-amiláz és $\alpha$ glükozidáz, mint az étrendi poliszacharidok glükózfelszabadításának enzimei, potenciális célpontjai az új, elhízás elleni és antidiabetikus gyógyszerek fejlesztésének. Az általánosan elfogadott terápiás stratégia az étkezés utáni hiperglikémia szabályozására az $\alpha$-glükozidáz és az $\alpha$-amiláz enzim gátlása. Ezen enzimek gátlása jelentősen késlelteti a szénhidrát lebomlását és a monoszacharidok felszívódását és a posztprandiális hiperglikémiát. Az akarbóz egy ilyen hatáson alapuló antidiabetikus gyógyszer, amely gátolja a hasnyálmirigy $\alpha$-amilázt és az intestinalis $\alpha$-glükozidázt. Azonban ez a hatóanyag nemkívánatos gasztrointesztinális és máj mérgező mellékhatásokkal rendelkezik. Ezért egyre növekvő igény van arra, hogy hatékony, természetes hatóanyagokat találjanak káros mellékhatások nélkül. A posztprandiális glikémiás válaszokat vizsgáló klinikai vizsgálatok kimutatták az élelmiszerrekkel bekerülő polifenolok jelentőségét a vércukorszintek csökkentésében. Mivel a vadon élő bogyós növények különösen gazdagak e vegyületekben az erdei szamócát, szedret és áfonyát választottunk ki a glikozidáz enzimek gátló hatásának vizsgálatára és a terápiás hatásuk elemzésére a posztprandiális hiperglikémia enyhítésében. A munkám során az $\alpha$-amiláz aktivitásának és gátlásának mérésére új eljárást dolgoztam ki, amellyel különböző növények kivonatainak $\alpha$-amiláz gátlását tudtuk mérni. A magas gátlással rendelkező növények kivonatát teszteltük in vitro az $\alpha$-amiláz és az $\alpha$-glükozidáz enzimekre. Az $\alpha$-amiláz mérésére kifejlesztetünk egy új HPLC alapú módszert, melyel specifikusan csak az adott enzim által hidrolizált szubsztrát mennyiségét tudjuk mérni. Szubsztrátként 2-klór-4-nitro-fenil- $\beta$-D-maltoheptozidot (CNP-G7) használtunk, melyet kémiai szintézissel állítottunk elő és kromatográfiásan tisztítottuk. A szubsztrát tisztaságát folyadékkromatográfiával és MALDI-TOF-MS készülékekkel ellenőriztük. Az enzimmérésekhez a tisztított CNP-G7 szubsztrátot használtuk, amely több hatékony kötést tud létrehozni a HSA aktív centrumával ezért a kromatogramon három, különböző hosszúságú termék csúcsa is látszódik, melyek megfelelő módszerrel elválaszthatók egymástól és a szubsztráttól Az enzimaktivitás sebességének jellemzésére a fó termék, a CNP-G3 keletkezésének a sebességét határoztuk meg. A különböző időpontokban injektált minták kromatogrammján a CNP-G3 hoz tartozó csúcs területét mértük és ábrázoltuk az idő függvényében. Ez a szubsztrát már elég hosszú, hogy átfedje a humán nyál amiláz (HSA) aktív helyét és a természetes szubsztráthoz hasonlóan viselkedjen. A HSA és a szubsztrát reakciója 
során a három felszabaduló redukáló végtermék fö összetevője a CNP- $\beta$-D-maltotrióz (CNPG3) amely a szubsztrát detektálható reakciótermékeinek 50\%-át teszi ki. Az aglikon kromofor lehetővé teszi az UV-tartományban (302 nm) való magas érzékenységgel való detektálást, amely béta-glikozid kötéssel kapcsolódik a szénhidrát lánchoz, melyet az $\alpha$-amiláz nem képes hasítani. A korábbi kalorimetriás titrálási (ITC) módszerrel végzett vizsgálatok megerősítették, hogy a CNP-G7 a keményítőhöz hasonlóan hasad az enzimreakcióban. Az eredményeink megerősítették a HPLC-alapú kinetikai módszerek alkalmazhatóságát az $\alpha$-amiláz aktivitásának megbízható meghatározására.

A kísérleteinkhez 9 növény kivonatát készítettük el, melyeknek megvizsgáltuk az $\alpha$ amiláz gátló hatását. Azt tapasztaltuk, hogy a kontrollvegyületként alkalmazott akarbózhoz képest a kivonatok $\alpha$-amiláz gátlásának $\mathrm{IC}_{50}$ értéke nagyobb volt. A vizsgálatainkat ezután az erdei szamóca, áfonya és szeder kivonatok analízisére szűkítettük, és ezen kivonatoknak $\alpha$ glükozidáz gátló hatását mértük. A mérések alapján kijelenthető, hogy a növényi kivonatok gátolják ezen enzim müködését is és hasonlóan az $\alpha$-amilázhoz, magasabb $\mathrm{IC}_{50}$ értékkel rendelkeztek mint az akarbóz. A három kiválasztott kivonat egyenlő arányú keverékét képezve is meghatároztuk a glikozid hidroláz enzimek aktivitására kifejtett gátló hatást. Továbbá a tannin kivonásával meggyőződtünk róla, hogy a gátló hatásért nem csak ez a vegyületcsoport a felelős. A kísérleteink alapján kijelenthető továbbá, hogy a kiválasztott kivonatok jelentős antioxidáns hatással rendelkeznek. A növényi extraktumok összetételét tömegspektrométerrel vizsgáltuk. A mérés során kationizált kvázi molekula ionokat alkalmaztunk arra, hogy képet kapjunk a lehetséges összetevőkről. Az összegképletek alapján feltételezhető, hogy a növényi kivonatok különböző flavonoidokat és ezek glikozidjait, kondenzált és hidrolizált tanninokat katekineket tartalmazhatnak, melyeknek biológiai aktivitása az irodalomban már jól jellemzett, de mint glikozidáz inhibitorok eddig még nem voltak a kutatások célpontjai. A vegyületek sokszínüsége arra enged következteni, hogy a bioaktív komponensek nem csak egyetlen molekulához köthetők, hanem több vegyülethez ami az $\alpha$-amilázt, és az $\alpha$-glükozidázt is hatékony gátolhatja.

Az állatkísérletek előtt annak megállapítása érdekében, hogy a kísérletre szánt növényi hatóanyagok milyen hatást gyakorolnak a sejtekre in vitro citotoxicitási- és citoprotekciós tesztet végeztünk. Elmondható, hogy a kivonatok nem mutattak citotoxicitást, sőt esetenként serkentették a sejtekéletképességét, de ennek ellenére nem mutattak citoprotekciós hatást az alkalmazott kísérleti elrendezésben. Két cukorbeteg modellben is teszteltük az általunk alkalmazott növényi kivonatok keverékét. A 2.-típusú cukorbetegség tesztelésére magas zsírtartalmú és magas szacharóz (HFHS) tartalmú táplálék által előidézett prediabetikus elhízási 
modellt alkalmaztuk. Ezeket a kísérleteket hím C57B16 egereken hajtottuk végre, amelyek hajlamosak a táplálék által kiváltott elhízásra. A másik diabéteszes állat modellben CD1-es típusú állatokon végzett kísérletekben az 1.-típusú cukorbetegséget az STZ- indukálásával hoztuk létre. Ezeknél az egereknél kétszer vizsgáltuk, a növényi kivonatok hatását az STZkezelést követő 5. és 10. napon. Ezzel a módszerrel az akut és a kronikus cukorbetegségben lévő klinikai paraméterek változását tuttuk követni. Munkánk eredményeként beszámoltunk arról, hogy az általunk alkalmazott növénykivonatok hatékonyan enyhítették az oldható kukoricakeményítő által indukált "postprandiális" vércukorszint emelkedést normál egerekben és a hiperglikémiát prediabetikus és STZ indukált cukorbeteg állatmodelleken. Ez a hatás valószínüleg az áfonya a szeder és az erdei szamóca leveleiből származó vízoldható extraktumok által az $\alpha$-amiláz és az $\alpha$-glikozidáz enzimek gátlásán keresztül valósul meg.

A H9c2 patkány embryonális szívizomsejtjein valós idejü sejtes elektronikus érzékelési tesztet alkalmazó in vitro vizsgálatok jelezték, hogy a különböző növényi kivonatok nem toxikusak az $1 \mathrm{mg} / \mathrm{ml}$-ig terjedő dózistartományban. Továbbá, nem figyeltünk meg akut in vivo toxicitást az egereknél az 1200 mg/ttkg növényi kivonat alkalmazását követően sem. A jelenlegi in vitro és in vivo adatok azt sugallják, hogy a növényi kivonatok anti-hiperglikémiás hatása összefügghet a bél $\alpha$-glükozidáz és az $\alpha$-amiláz gátlásával, azonban a gátlás az endogén glükóz termelés és a glükóz felvétel stimulálása, valamint az inzulinszekréció fokozódása az anyagok hatására szintén nem kizárható. A növényi kivonatok nem toxikusak, és nem mutattak látható mellékhatásokat, ezért a jövőben alkalmazhatóak lehetnek a hiperglikémia jövőbeni kezelésére a 2-es típusú cukorbetegség esetén. 


\section{Angol nyelvü összefoglaló}

The successful treatment of hyperglycemia is crucial in the management of metabolic syndromes such as type II diabetes. The glycoside hydrolases are usually targets of these antidiabetic treatments and in diabetes research involving $\alpha$-amylase and $\alpha$-glucosidase enzymes, which play an essential role in glucose release hydrolysing starch. It is a commonly accepted strategy to manage hyperglycemia by the inhibition of $\alpha$-amylase and $\alpha$-glucosidase. The inhibition of these enzymes could prevent the adsorption of glucose along with the postprandial hyperglycemia. One member of these type drug molecules the acarbose, which is widespread applied antidiabetic drug that inhibit pancreatic $\alpha$-amylase and intestinal $\alpha$ glucosidase. Although, it could be used effectively, it shows several unpleasant gastrointestinal and liver toxic side effects. This is the reason that there is a common need for new molecules possessing less side effects. Several clinical studies have been demonstrated the effectiveness of the food polyphenols in the treatment of high blood glucose levels. The berries are usually rich in these compounds, therefore, wild strawberry, bilberry and blueberry were selected in our study for the extraction of their valuable bioactive components and to assay the properties of these extracts to reduce postprandial hyperglycemia in vitro and in vivo. For these purposes, in our study a novel method was developed for measuring $\alpha$-amylase inhibition activities. The novel method is based on HPLC separation and specified to measure the rate of $\alpha$-amylase hydrolysis. As the enzyme specified substrate we used 2-chloro-4-nitro-phenyl- $\beta$-Dmaltoheptoside (CNP-G7) that was synthetized chemically and purified with chromatographic method. The purity of the substrate was than investigated and confirmed with HPLC and MALDI-TOF-MS. For the inhibition assays, this purified CNP-G7 and human salivary enzyme (HSA) were used. The substrate binds to the active centrum of the HSA that results three separated peaks on the chromatograms, which chromophore aglycon makes it possible to measure the product at $302 \mathrm{~nm}$ with high intensity.

Firstly, nine different plants were extracted with hot water and after their lyophilisation they were screened for $\alpha$-amylase inhibition. After that based on their $\alpha$-amylase inhibition activities three of them were selected and investigated in further experiments including their $\beta$ glucanase inhibition-and antioxidant activities. The selected plants were the wild strawberry, bilberry and blueberry showing outstanding results in glycoside hydrolase enzyme inhibition.

To investigate the possible reason of the inhibition, tannin precipitation was carried out to prove that not only these types of molecules can be noted as inhibitors. Furthermore, the 
chemical composition of extracts were also analysed with mass spectrometry. We recorded the produced protonated and alkali adduct molecular ions to get the molecular formula of the constituents. From the analysis, it could be assumed that the selected plant extracts contained flavonoids and flavone-glycosides, condensated and hydrolysed tannins and catechins. The bioactivity of these compounds is well defined, but as glycosidase inhibitors they have not been tested so far.

Before the applications of the plant extracts on animal model, their in vitro cytotoxic and cytoprotective effects were assayed on cell lines. It could be concluded that the extracts did not show toxicity to the cells rather they boosted the cell functions. Although the extracts did not cause toxic effects, protective influences to the cells could not be observed.

After the in vitro experiments, for the in vivo investigations two diabetic mouse models were used to test the selected plant extracts. For type II diabetes, high fat high saccharose induced (HFHS) pre-diabetic obese model was applied. In this examinations C57B16 mice were involved, which were susceptible to diet induced obesity. Furthermore, for the testing the extracts on the type I model, the streptozotocin treated mice were used. The effects of plant extracts, the blood sugar levels were measured in the fifth and tenth day after the STZ induction to model the parameters of acute and chronic clinical diabetic. The applied plant extracts efficiently attenuated the water-soluble corn starch induced postprandial hyperglycemia in both normal and diabetic mice. This effect may be occurred by the inhibition of $\alpha$-amylase and $\alpha$ glycosidase, but influence of other physiological process could not be excluded.

The plant extracts are not toxic and did not show any side effects, consequently it can be used as subsidiary in the treatment of diabetes. 